UCRL -53154

DE82 016139

\title{
Swedish Nuclear Waste Efforts
}

\author{
Jan Rydberg
}

Manuscript date: September 1981

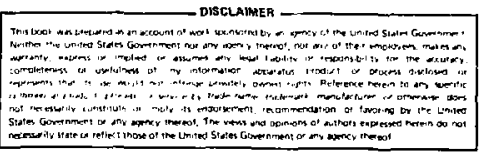

\section{LAWRENCE LIVERMORE LABORATORY University of California - Livermore, California $\bullet 94550$}




\section{PRGFACE}

The 1976 Parliamentary election in Sweden resulted in a coalition government which imposed extremely stringert requirements for the waste produced by Swedish nuclear power plants. The industry responded with a crash study, the Nuclear Fuel Safety (RBS) project, with experts drawn irom hundreds or universities and related scientifis institutions. A year later, the industry presented "a complete scheme for absolutely safe storage of nuclear waste" In engineered facilities located at about $500 \mathrm{~m}$ depth in the Swedish granite bedrock (RBS-I). This was considered the first comprehensive and coherent scheme for "final" nuclear waste disposal. The kBS-I study was not only extensively examined and debated, it also brought down the coalition government.

This first study was later followed by others (the kBS-II scheme) and extensive research and development work in Sweden on all aspects of nuclear waste management. It is believed that in this area Sweden has the most complete program, attracting considerable international interest. Due to special circumstances I have been engaged on both the industry and government side of this project.

Early in 1980, while spending a sabbatical year from the Chalmers University of Technology in Gothenburg, Sweden, at the Lawrence Livermore National Laboratory, I presentec a lecture on the RBS project at the Hoover Institution on War, Revolution and Peace. It met with great interest and-at the request of Dr. R. Williams of the Electric Power Research Institute--I have now written a brief summary of the Swedish nuclear waste activities using many of the actual illustrations from RBS reports. I hope that this synopsis can serve as a somewhat easier source of information than the 2-3 meters of reports so fal presented by the kBs project.

I sincerely thank all of the organizations mentiused above and in the text for extensive help in presenting this report. I also want especially to thank Dr. Chris Gatrousis of Lawrence Livermore National Laboratory for his support. 
Preface

Abstract

Introduction

1. The Stipulation Law .

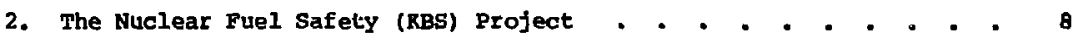

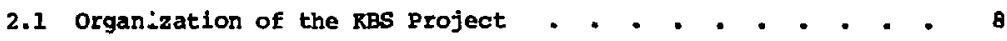

2.2 Selection of Waste Management Scheme . . . . . . . . . 12

2.3 Spent Fuel storage Ficility . . . - . . + . . . . . 1t

2.4 Selection of Final storage site (Depository) . . . . . . 17

2.5 Dispasal of Unreprocessed Spent Fuel Elements . . , , . . 20

2.6 Handling of Reprocessing Waste . . . . . . . . . . . 32

2.7 Safety Analysis of the Final Depository . . . . . . . . 38

2.7 .1 GeologY and BydrologY . . . . . . . . . . . 38

2.7 .2 Radlation Effects . . . . . . . . . . . . . 39

2.7 .3 Heat Effect . . . . . . . . . . . . . . 39

2.7 .4 Dissolution Rater. . . . . . . . . . . . . 41

2.7.5 Radionuclide Transport Through the Ground . . . . . 42

2.7.6 Dase Calculations . . . . . . . . . . . . . 44

2.8 Reylews of the KBS Project . . . . . . . . . . . . 48

2.8 .1 RBS I (Disposal of Reproceasing Naste) . . . . . . 51

2.8 .2 RBS-II (Disposal of Unreprocessed

Spent Fuel Elements) - . . . . . . . . . 52

2.9 Recent Changes - . . . . . . . . . . . . . . . 54

3. present Research Efforts. . . . . . . . . . . . . . . 57

3.1 RBS Regearch and Development Efforts . . . . . . . . . 57

3.1.1 Identification and Selection of Rock

Bodies for Taste Disposal . . . . . . . . . . 57

3.1 .2 Selgmicity and Neotectonics . . . . . . . . . 59

3.1 .3 Hydrogeology . . . . . . . . . . . . . 59

3.1 .4 Geochemlstry . . . . . . . . . . . . . . 59

3.1 .5 Stripa Experiments . . . . . . . . . . . . 60

3.1 .6 Safety Analysis . . . . . . . . . . . . . 60

3.1 .7 Glasg Research . . . . . . . . . . . . . . 61

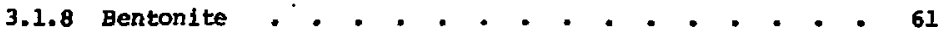


3.1.9 Waste Handling . . . . . . . . . . . . . 61

3.1 .10 CLAB . . . . . . . . . . . . . . . . . 61

3.1 .11 SFR . . . . . . . . . . . . . . . . . 61

3.1 .12 Transportation - . . . . . . . . . . . . . 62

3.1 .13 Time Schedule . , . . . . . . . . . . . . 62

3.2 The stripa Project - . . . . - . . . . . . . . . 62

3.3 Asea Ceramic Canister .. . . . . . . . . . . . . . 65

3.4 National Council for Rnöloactive Waste . . . . . . . . 69 Appendices

Appendix A Technical Reports - . - . - - . . - . - . - A-1

Appendix $B$ contracted and Consulting companies, Institutions and Experts . . . . . . . . . . B-1

Appendix $C$ Hydrological studies of a Potential Waste Repository in Granite: A Survey of the stripa Project . . - . . - . + . - . . C-1

Appendix D Equations for Fracture Conductivity (SAC-17) • • • - D-1

Appendix E Law on Nuclear Waste, July l, 1981
(TRANSLATION) - . . . . . . . . . . . . E-1 


\section{SWEDISE NOCLEAR WRSTE EFFORTS}

\section{ABSTRACT}

After the Introduction of a law prohibiting the start-up of any new nuclear power plant until the utility had shown that the waste produced by the plant could be taken care of in an absolutely safe way, the swedish nuclear utilitles in December 1976 embarked on the Nuclear Fuel Safety Project, which In November 1977 presented a first report, "Handling of Spent Nuclear Fuel and Final storage of Vitrifled Waste" (RBS-I), and in November 1978 a second report, "handling and Final storage of Unreprocessed spent Nuclear Fuel" (RAS II). These summary reports were supported by 120 technical reports prepared by 450 experts. The project engaged 70 private and governmental institutions at a total cost of US\$15 million.

The RBS-I and KBS-II reports are simmarized in this document, as are also continued waste research efforts carried out by KBS, SRBF, PRAV, ASEA and other Swedish organizations.

The RBS reports describe all steps (except reprocessing) in the handling chain from removal from a reactor of spent fuel elements until their radioactive waste products are finally disposed of, in canisters, in an underground granite depository. The RBS concept relies on engineered multibarrier systems in combination with final storage in thoroughly investigated stable geologic formations. The barrier systems are

- for reprocessed waste: waste bound in glass matrix and surrounded by layers of stainless steel, lead (100 mul and titanium.

- for unceprocessed spent fuel elements: waste bound in $\mathrm{UO}_{2}$ matrix surrounded by layers of zircaloy, lead and copper (200 $\mathrm{mm}$ ) .

The canisters are 0.6 and $0.8 \mathrm{~m}$ in diameter and 1.8 and $4.5 \mathrm{~m}$ long, respectively. The waste is allowed to cool altogether in interim storage for 40 years, until the canisters are emplaced in a bed of bentonite clay holes drilled in the floor of tunnels about $500 \mathrm{~m}$ deep in granite bedrock. The clay is highly impermeable to water and provides an elastic support for the canisters. Due to the low waste content of the canisters (each containing waste from about one tonne spent uranium fuel), the thick canister walls, and long cooling times, the radiation and heat lad on the surroundings become 
almost negligible: maximu canister surface terperature is $77^{\circ} \mathrm{C}$ and maximum rock temperature $60^{\circ} \mathrm{C}$. These low temperatures reduce the corrosion rate of the canister, 80 its lifetime greatly exceeds 10000 years. The reducing properties of the groundwate:: expand this lifetime to over a million years. The low tomeratures and raclation flelds aleo ensure that no unexpected chemical reactions w1ll occur between wate, canister aterials, clay, rock, and groundwater. Rock retention of the waste nuclides contributes to the KBS prediction that even under the worst possible conditions ("most pessinistic case") the radioactive nuclides, which way leak out, will be in such swall amounts, that the doses to critical groups living near the repository will never exceed the natural radiation doses. The KBS thus contends that their waste handling concept leads to an absolutely safe storage of radioactive waste, in compliance with the law.

The KBS project has, in general, received strong support from the large number of Swedish and foreign reviewing agencies, e.g., the 0.s. National Acaderay of Sciences. Since the LBS concept contains any of the conditions set forth in the Department of Energy proposal (DOB/NB 007) it upholds the Department of Energy's view that radioactive waste can be safely disposed of.

This report aleo briefly describes other activities carrled out by the nuclear Industry, namely, the construction of a central storage facility for spent fuel elements (to be in operation by 1985), a repository for reactor waste (to be in ogeration by 1988), and an Interiediate storage facility for vitrifled high-level waste (to be in operation by 1990). The RaD activities are updated to September 1981.

\section{INTHODOCTION}

In 1975 the Swetish Parliament decided on a program of 13 nuclear reactors to be in operstion before 1985 and with a capacity of about $10 \mathrm{~W}$ (the 1976 total electric capacity of sweden was 20Gi, mainly water power). of thege, 6 were in operation at the end of 1976 with a capacity of 3.8 $\mathrm{GH}$, providing about 20 s of the swedish electricity demand. Through the 1976 parliamentary elections a congervative coalition government cane into power, atrongly bupported by antinuclear groups. In Octiver 1976 the new government 
declared that, because of the riskg of nuclear porer, it would allow no new nuclear power atations to be charged until the power industry had desonstrated how and where elther the spent fuel elenents ox the high-active waste from reprocessing could be stored in an absolutely safe unner, in principle, for eternity. This declaration was later reworded in the Stipulation Lav (Section 1 below).

In order to comply with the law, the Swedish nuclear power utilities organized the Nuclear Fuel Safety (KBS) Project. Through efficient planning and the cooperation of some 70 private and government institutions, a first report regarding the "Handling of Spent Nuclear Fuel and Final storage of Vitrifled High Level Reprocessing Waste" (KBS-I) was ready in Kovember 1977. The power utilities claimed that this report fulfilled the requiremunts set forth in the Stipulation Iaw and requested permission from the covernment to start up two more reactors. As is customary in Sweden, the report was submitted for the review and cownents of Swedish federal organizations, universities and research institutions (not previously involved in the kBS profect), and by selected international organizations. Since the coalition partners of the Government could not agree on how to interpret the conclusions of the reviewers, most conclusions being favorable but sone being critical, the calitian government resigned in October 1978. The successor conservative minority government in March 1979, approved the KBS-I concept after sowe further geologic studies, as providing an "absolutely safe waste storage," and issued permits to charge the Ringhals 3 and Forsmark 1 reactors.

In late 1978 the RBS Project issued Its second report, concerning the "Handling and Final storage of Onreprocessed Spent Nuclear Fuel" (KBS-II). KBS-II, like KBS-I, has been sent out for review and comments. These coments have now been recelved and collected in a report, awalting further decisions of the nuclear power industry.

The KAS-I and XBS-II projects are described in Section 2 below. Appenaix $A$ contains a list of the technical reports so far published (about 150), and the organizations involved in the projects.

The accident at Three Mile IBland in March 1979 led to a call for a referendum on nuclear energy in sweden. In the meantine a "tine-forconsideration-law" forbade charging any new reactors, including those which had recelved peralts a few weeks before. After an exceptionally intense and rancorous public debate the referendum was held in March 1980. The voters 
gave 58: support (39: agalnst, 3t blank) for the "Yes" alternatives of a naximum of 12 nuclear power stationg to be uaed during their econonic and operational lifetime. At this time six reactors were in operation, and three others were ready to be charged. The KBS-II project is likely to be used to aupport the starting of the tiniee remaining reactors; one will be ready in 1982, the two last ones in 1985.

Presently (Sept. 1981) 9 muclear power reactors producing a total $6.5 \mathrm{GH}$ are in operation, providing 358 of all Swedish electric power. In order to charge the three last reactors, it may be neceasary for the Government to review the kBS-II proposal.

It may be added that in the referendun, about $2 / 3$ of the voters supported the statement that nuclear power should be "a parenthesis," and that no nore reactors should be bullt after the completion of the present 12-reactor program.

The ras project has tried to address all practlcal aspects, from the transpurt of the spent reactor fuels away from the reactor to the permanent deposition of radioactive elements in an underground granite repository. Parallel to this work, resulting in the KBS-I and KBS-II reports, KBS or 1ts parent organization SKBF has aupported nore long-range studies of geologic repositories (at Stripa) and canlster materlal (at ASBA). The project has also been supported by funds from PRAV (see below). The KBS project has pointed to the need for further studies, particularly short-range pragmatic studies; some of these are described in Section 3.1.

The aultability of mined granite caverns for high-active waste storage has been studied in an abandoned mine at stripa, sweden, in a joint project between J.S. laboratories and KBS. Large-scale geophygical and hydrological parameters have been measured. Thls program has now expanded into an NEA (Nuclear Energy Agency) International project. These activities are summarized in Section 3-2 and in Appendix $C$.

The technigue for encasing spent nuclear fuel elements in canisters of highly corrosion-resistant corundum, developed by ASEA (Swedish General Electric Company), is described in section 3.3

In 1972 the swedigh Governient appointed the AkA conaittee, with responslbility to look over the issue of radioactive waste and propose actiona. In 1974 this comittee wa reglaced by the National council for Radioactive waste (PRAV). The KBS project has benefited from its cooperation 
with this council, whose main objective is to fund wore long-range research and developient on waste in the nuclear fuel cycle, as vell as on other radioactive wstes. The council's activities are described in section 3.4 . PRAV ceased to exist on June 30, 1981. Recent changes are described in section 2.9 . 


\section{THE STIPULATION IAH}

On Apr11 21, 1977, the Swedish Government prohibited owners of nuclear reactors from lading nuclear fuel into new reactors without special permission frow the Government. Permission could be granted only if the owner of the reactor elther:

1. had presented a contract for reliably reprocessing used nuclear fuels, and in addition had show how and where an absolutely safe ("helt saiker") final storing of the high-active waste from the reprocessing could be achieved, or

2. had shown how and where an absolutely safe ("helt säker") final disposal of spent unreprocessed nuclear fuel could be accouplished. The two alternatives are represented in Fig. 1. In the supplementary explanation of the law, it is stated that "absolutely safe" ("helt sixer") shall not be Interpreted in a "draconian" way. Although tiere is no officlal interpretation of "absolutely safe," it has been interpreted by Rydberg and Winchester (Sw. Dept. Energy, DsI 1978:17, p. II:22) to mean "that neither extreme happenings nor slow releaseg from the waste repository shall lead to radiation doses which now or in the future exceed the dose limits currently recommended by the International commission on Radiation protection (ICRP).- 


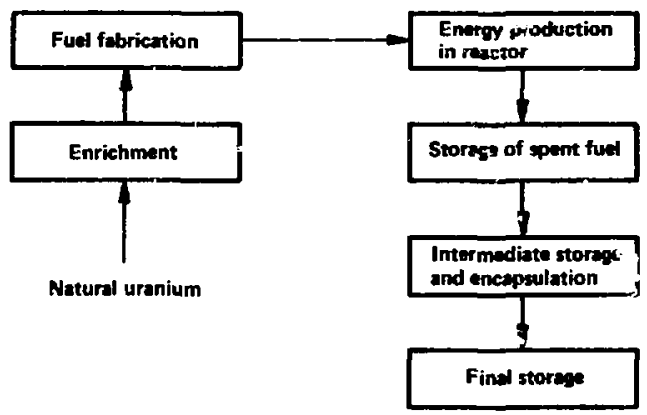

FIG. 1a. The direct deposition alternative (KBS-II). Flow echene fur the fuel cycle with airect storage of the spent fuel without reprocessing.

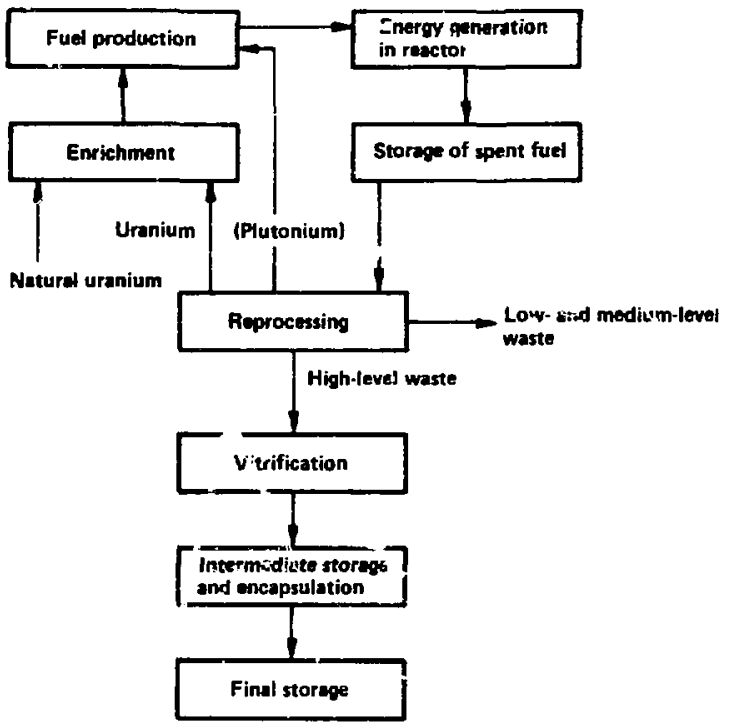

FIG. 1b. The reprocessing alternative (IBS-I). Flow schene for the fuel cycle with reprocessing of opent fuel and vitrification of the high-level waste. 


\section{THE NUCLEAR PUEL SAFETY (KBS) PROJECT}

The Swedish leyislation puts full responsibility for Investigations and demonstrations of the absolutely safe handing and storage of high-level waste on the owner of the reactor. It should be mentioned that use of the word "demonstration:" does nol Imply that facllitles shall be constructed and used to dispose of high-level waste or spent fuel. Bowever, detalled and compreherisive information must be provided for a safety evaluation.

\subsection{ORGANIZATION OP THE KBS PROJECT}

As soon as the Intentions of the new government becane known, the Swedish nuclear porer utilities, consisting of the state Power Board and private companies, organized a special joint project to meet the requirements of the stipulaton Law, called the KBS project (FIg. 2). KBS stands for the Swedish word "KärnBränslesäkerhet," whlch means nuclear fuel safety. The rapid organization was facilitated by the existing Blectric Porer Coordinating Board (Centrala driftledningen, CDL), an organization comprising all private and state electric porer conpanjes and their subsidiary, the Swedish Nuclear Fuel Supply Company (Svensk Rärnbränsleförsörjning AB, SkBF) in conjunction with the National Council for Radiosctive Paste (Progranrådet für radioaktivt avfall, PRAV). About 50 million Swedish crowns ( $\$ 10$ million) were immediately appropriated to the KBS Project Manager, and the time limit fo: completing a first report on the handling of reprocessing waste ("KBS-I"), which would comply with the cemand in polnt 1 of the Stipulation law, was set at one year. The main reason for this nasce was the fact that two nuclear power stations were standing idle, and every delay in starting up cost the power utilfties \$1-2 million per week. There was also a psycholngical reason: with every day the antinuclear forces seemed to grow stronger, supported by the major news media, focusing their criticlsm on the unsolved waste 1ssue. It was felt that it was important to show thet the waste problem could be solved before a majority of the public became convinced that it could never be solved.

The small project Management Group (sone 20 persons) sec up an organization according to Fig. 2 and five special reference groups (for Geology, Safety Analysis, Corrosion, Buffer Mater1als, and Progrannes). In addtion, 

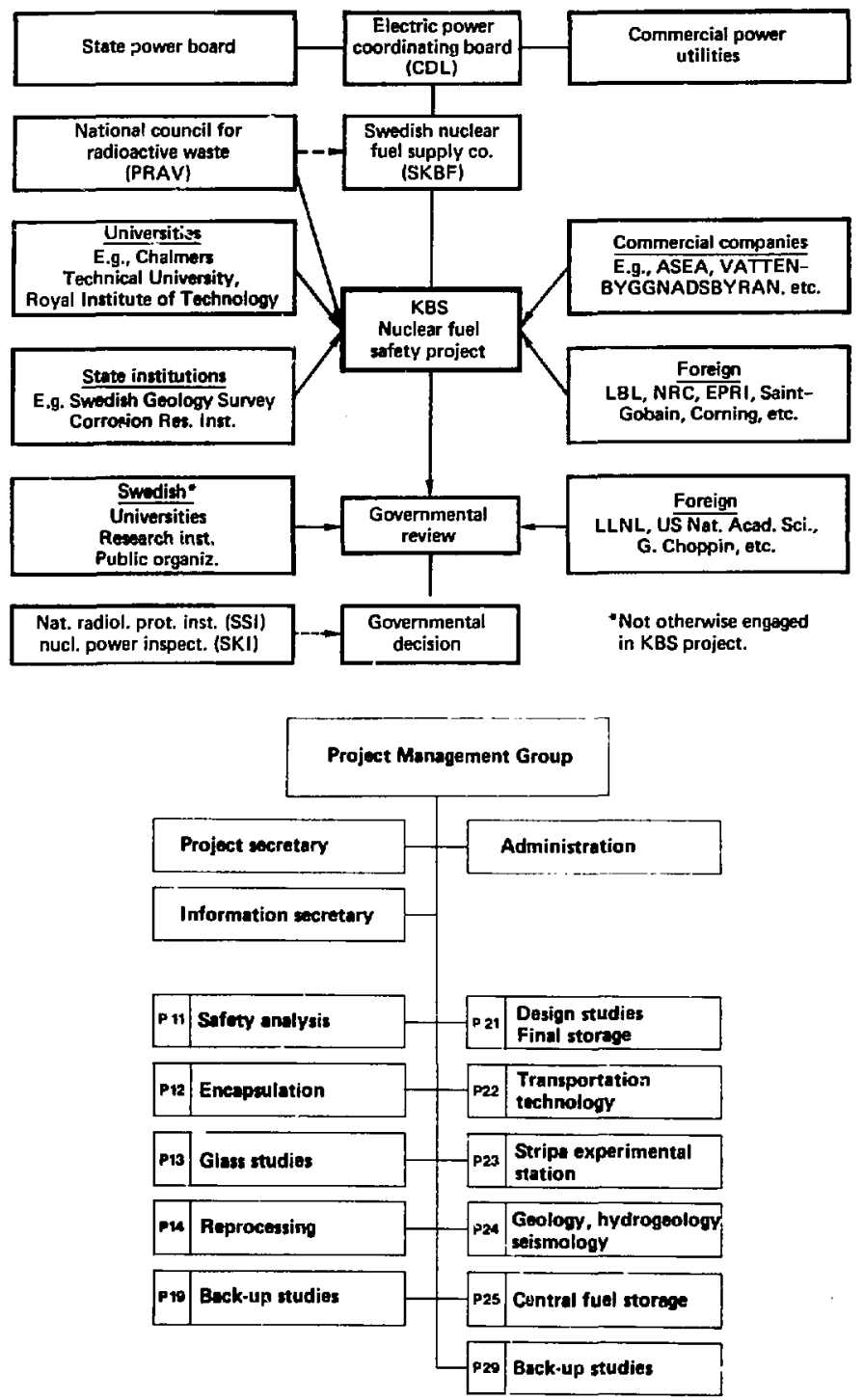

FIG. 2a. Organization plan (Institution and scientific projects) for the suclear Fuel Safety Project (RBS). 
MUCLEAR POWER UTHLITIES

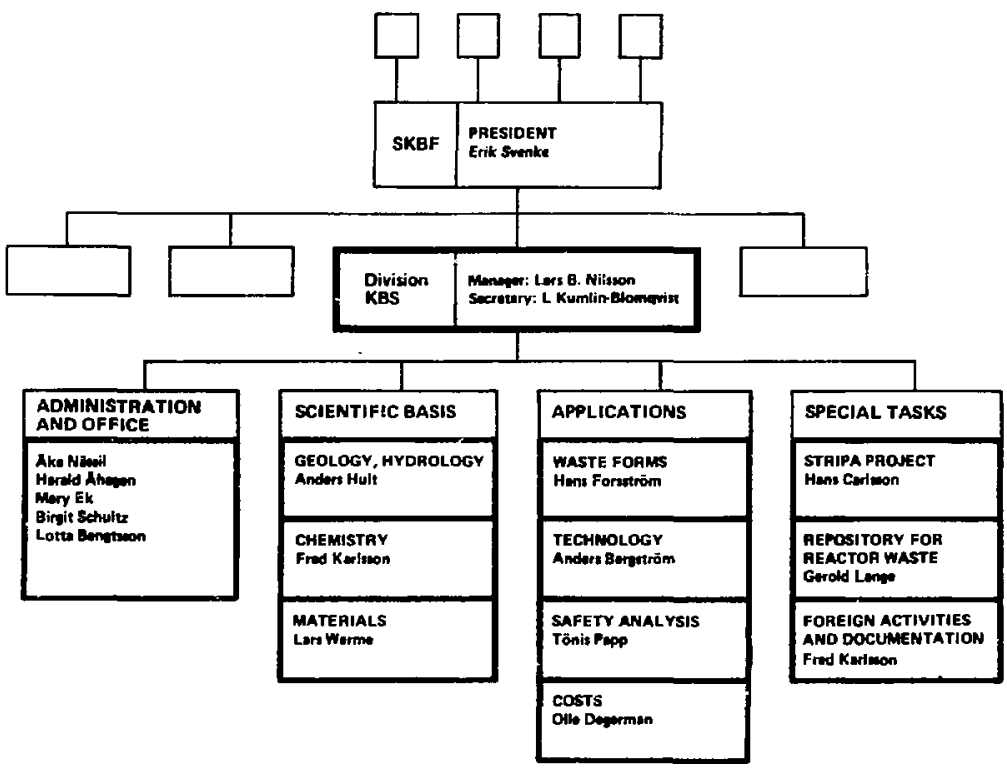

FIG. 2b. Organization chart of IBS management.

some 450 persons weve engaged through the contracting of consultints from Swedish and forelgn, private and state corporations and research institutions. The consultants are named in Appendix B.

In order for this gcheme to work it was essential that the Management Grow have a very free hand, In addition to dedication and high working capacity, much exceeding 50 hours per week for exhended perloda. (The average age of the Management Group was about 40.) It was also necessary to adopt the ph1losophy of relying on known techniques and known properties of materials, alnce there would be Insufficlent time for baslc research. By engaging the greatest expertiae in the country (and somet:- 3 from abroad) the cruclal difficultieg were pinpointed early, which led to some Inuediate deciaions among the waste managenent options (described in next section) as well as Imnedlate laboratory and fleld studles.

The first kas report (KBS-I) was finished 8 months after the stipulation Iav, or 13 months after the election of the new government. The main report 
was supported by 60 technical reports. The second report (xBS-II) required an additional half year, it was supported by another 60 technlcal reports. All report titles are given in Appendix $\mathrm{A}$. The expenses for both projects asounted to about $\$ 15$ million.

\subsection{SELECTION OF WISTE MANAGEMEYT SCHEYE}

The KBS studies deal with the handing of reprocessing raste (RBS-I) and the handling of unreprocessed spent fuel (KBS-II). In the following, both alternatives will be considered gimultanecusly, where possible, because of the desirability of a design which can acconmodate both optlons, leaving firal cholce to political institutions at a later time. The KBS handing schere, and particularly the varlous facilities designed for the handing, cones close to this flexiblifty, as indlcated in Fig. 3. The spent fuel elesents are tranaported from the reactor to a Central storage Facility (Centrallager for aktlut bränsle, CLAB), where they are allowed to cool for scme tine. In the reprocessing case, the spent fuel elenents are transported abroad to a

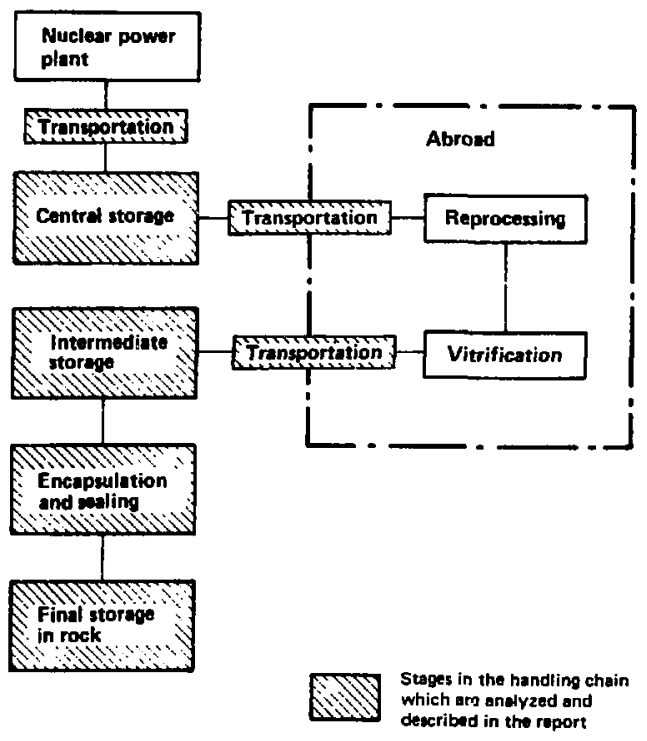

FIG. 3a. Handing chain for spent fuel and pitrified saste. 


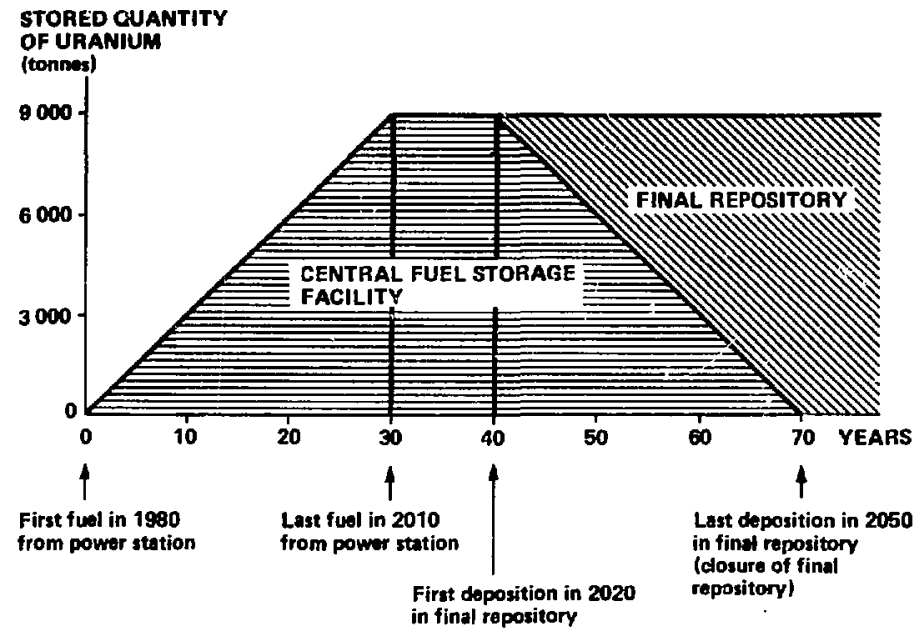

FIG. 3b. Diagram illustrating the capacity requirements from 1980 to 2050 for the central fuel storage faclilty and the final repository for KRS-II .

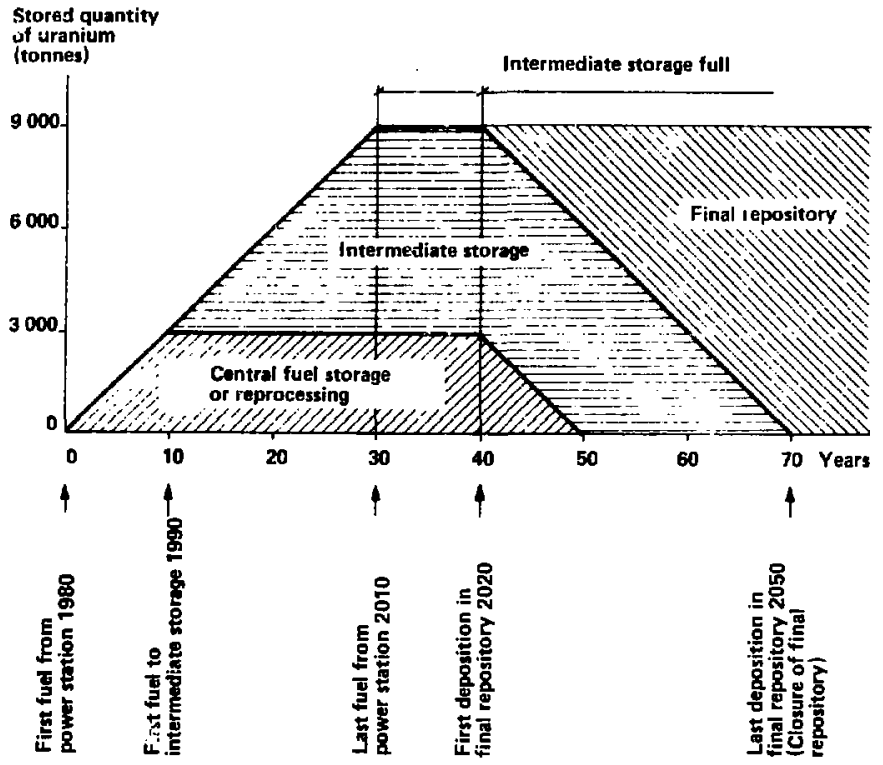

FIG. 3c. Diagram ahowing capacity requirementa from 1980 to 2050 for the centrul fuel storage facility and the final repository for KBS-T. 
reprocessing contractor, from which the vitrifled reprocessed waste is returned in steel canisters some time later. These canisters are stored in an Internediate storage Facility before they are recapped, sealed, and enplaced In the Final Depository. In the no-reprocessing case, the spent fuel elewents are kept in the CLAB until it is time for recapping and deposition. In this latter case, the Intermediate storage Facility is not needed, but all other facilities are common, including the transportation system.

The IaS design is based on a nuclear power progran of 12 reactors (mostiy boiling-water reactors), wich during their lifetiwes are assuned to produce 9000 tonnes of spent fuel elements. (A $1 \mathrm{GH}$ nuclear power station discharges annually 20 to 25 tonnes of opent uranium fuel (SUF).) since each tonne will produce approximately one canister of waste, either sollaifled reprocessing wate or spent fuel elements, the total program anounts to about 900 n canisters. The first shipwents of tpent fuel to the Central storage Facility will begin around 1985, and the maximum handing anount (about 260 tonnes of spent fuel a year) w11l be reached around 198\%. Extra space will tenporarily be rented out to Finland.

The waste-handling scheme covers the route from the input naterlal lspent fuel elements) to the final deposition of the waste. Table 1 sumarizes the

TABLE 1. KBS selected conditions for final storage of high-active waste.

Waste conditions

Barrier system

Location

Physical conditions
Reprocessed high-active waste in glass (KBS-I). Unreprocessed spent fuel elements (KBS-II).

Bnglneered (Eultilayers of metals). Bentonite clay (a natural naterial). Nature (grantte bedrock at $500 \mathrm{~m}$ depth).

Ear thquake-free, low-fault zone.

Valueless minerals. Iow groundwater flow.

Site percolated by groundwater. Maximum temperature cutside canister $<100^{\circ} \mathrm{C}$. Very low radiation field. 
felected final conditions. These conditions developed during the kBS project and were not prescribed, or later npproved, by any authority. The only design goal has been the stipulation by the law that storage be "absolutely safe" (as Interpretisd above).

It was obvious that the safest storage place in sweden would be in the granite rock which underlies most of the country. This 600-mililon-year-old rock bciy is considered among the most stable in the world. Bowever, the rock is permeated by groundwater even at considerable depth. The design had therefore to take into account corrosion by groundwater, and the possibility that dissolved waste may be transported from the depository to reservolrs of water for human use. The effect of sorption of dissolved waste from groundwater onto rock surfaces was not known at the time a waste-handling scheme had to be decided on. It turns out that sorption reduces the velocity of waste transport, but since this effect could not be taken into account, the chosen design was ultra-conservative:

(i) In order to eliminate radiation effects between waste, canister, groundwater, and rock, which could lead to high corrosion rate, the waste was to be surrounded by a radiation shield (lead or copper).

(ii) In order to slow down the rate of dissolution and other reactions with the environment, the maximun canister surface temperature was not allowed to exceed $100^{\circ} \mathrm{C}$. This could be achieved by reducing the waste amount of each canister to about I tonne SUF and by having a rather long cooling period to allow radioactive decay to reduce the heat output. Storage for unreprocessed spent fuel would be 40 years in water-filled pools. The reprocessing plan called for 10 years of ponl storage, and 30 more years of storage-after reprocessing-in an "intermediate-storage" facility.

(1ii) A multilayer barrier system was selected, each barrier having an independent high corrosion resistance, so that if one barrier failed there would be a high probability that the others would not. To meet this purpose the metals lead, titanium and copper were chosen. As a backup, corundum canisters were developed.

(iv) In order to reduce the risk of mechanical damage by geologic faulting, the canisters were tis be supported by an elastic "backfill" material (grartz plus bentonite clay).

In later studies, some of these materlals have been found even more advantageous than when originally contemplated. In addition, retention of the radionuclides by the rock has been found to be another powerful barrier. 
The canister cauposition, waste content, and dimensions are sumarized in Table 2 for the two concepts. Although the amount of radioactive waste is about the same in the two concepta, the reprocessed spent fuel canisters are much lighter, due to the selection of copper Instead of lead as radiation shielding. Copper was chosen for the spent uranium fuel because the corrosion resistance was considered higher.

THBLB 2. Some data for the two concepts for storage of high-level waste and spent uranlum fue.?.

\begin{tabular}{|c|c|c|}
\hline Property & $\begin{array}{l}\text { Reprocessed vitrified } \\
\text { hIgh-level wate }\end{array}$ & $\begin{array}{l}\text { Unreprocessed } \\
\text { gpent uranium fuel }\end{array}$ \\
\hline Equivalent waste anount & From 1 tonne $S U^{b}$ & 1.3 tonne sur \\
\hline Central part composition & $\begin{array}{l}120 \mathrm{~kg} \text { borosilicate } \\
\text { glass with } 94 \\
\text { fission products }\end{array}$ & $\begin{array}{l}550 \text { fuel pins + } \\
\text { lead in volds }\end{array}$ \\
\hline Central part weight & $\begin{array}{l}450 \mathrm{~kg}, \text { incl. } 3 \\
\text { stainl. steel cltading }\end{array}$ & $\begin{array}{l}2 \text { tonne fuel } \\
+2.5 \text { tonne lead }\end{array}$ \\
\hline Outer canning & $\begin{array}{l}100 \text { lead }+ \\
6 \text { titanium }\end{array}$ & 200 copper \\
\hline \multicolumn{3}{|l|}{ Canister: } \\
\hline Dimenatons & $0.6 \times 1.8 \mathrm{~m}$ & $0.8 \times 4.7=$ \\
\hline Weight & 3.9 tonne & 20 tonne: \\
\hline Surface tenp max & $65^{\circ} \mathrm{C}$ & $77^{\circ} \mathrm{C}$ \\
\hline Surface teng after 1000 yr & $35^{\circ} \mathrm{C}$ & $50^{\circ} \mathrm{C}$ \\
\hline \multicolumn{3}{|l|}{ Bentonite backfill } \\
\hline (outer barrler) & $0.2 \mathrm{~m}$ & $0.4=$ \\
\hline Rock hole dimensions & $1.0 \times 5.0 \mathrm{~m}$ & $1.5 \times 7.7=$ \\
\hline
\end{tabular}

aft 33000 wa/tonne 0 burn-up.

b38 $\mathrm{kg}$ Elssion producte (wP), $<3 \mathrm{~kg} \mathrm{~J},<0.05 \mathrm{~kg} \mathrm{Pu},<1 \mathrm{~kg}$ other transurantum elements.

GGlass of this composition will be returned to sweden after reprocessing at the French site at in Hague.

daximum temperature reached about 15 years after discharge of fuel from the reactor. 
The handing timetables are presented in Table 3 and in Fig. 3. All Swedish power reactor waste should be deposited and the depository closed by year 2050, according to these schemes.

\subsection{SPENT FUEL STORAGE FACILITY}

Regardless of whether the spent fuel is to be reprocessed or alsposed of without reprocessing, additional storage capacity away from the reactors is required for the spent fuel. RBS proposes a storage time of 10 years before eventual reprocessing, and of 40 years if the spent fuel is not to be reprocessed. Storage will be in water-filled basins underground, see Fig. 4 . The corrosion experlence fran zircaloy-clad fuel is so good that no additional canning is considered. Storage will be in racks, so that $k_{\text {eff }}<0.95$ even for new unused fuel; thus criticality risks are eliminated. The water will be cooled by sea water through heat exchangers. Pool temperature will rise to $40^{\circ} \mathrm{C}$ if one heat exchanger breaks down, and to about $85^{\circ} \mathrm{C}$ if all break down. The facility has an autamatic water level control syster connected to a surface lake.

The Government has 1 icensed SKBF to construct the Central Fuel storage Facility (CLAB), to be located close to the Oskarshamn nuclear power plant on the Baltic Sea. The facility is uxpected to be ready in 1985 with a capacity

TABIE 3. The KBS waste-handling schemes.

Time

(Yr) High-level wastes (KBS-I) Spent fuel elements (KBS-II)

\begin{tabular}{ll}
\hline 0 & \multicolumn{1}{c}{$\begin{array}{c}\text { Removal from reactor } \\
\text { Cooling in reactor pond }\end{array}$} \\
$\begin{array}{l}\text { Cooling In central pool facility } \\
2-10\end{array}$ & $\begin{array}{l}\text { Transport to reprocessing plant } \\
\text { Return of high-active waste in glass } \\
\text { Storage of cans of high-active waste } \\
\text { in glass in air-vented underground } \\
\text { vaults }\end{array}$ \\
40 & $\begin{array}{l}\text { Additional canning in lead } \\
\text { and titanium }\end{array}$ \\
40 & Final deposition at 500 m depth in \\
clay-filled holes in granite bedrock
\end{tabular}




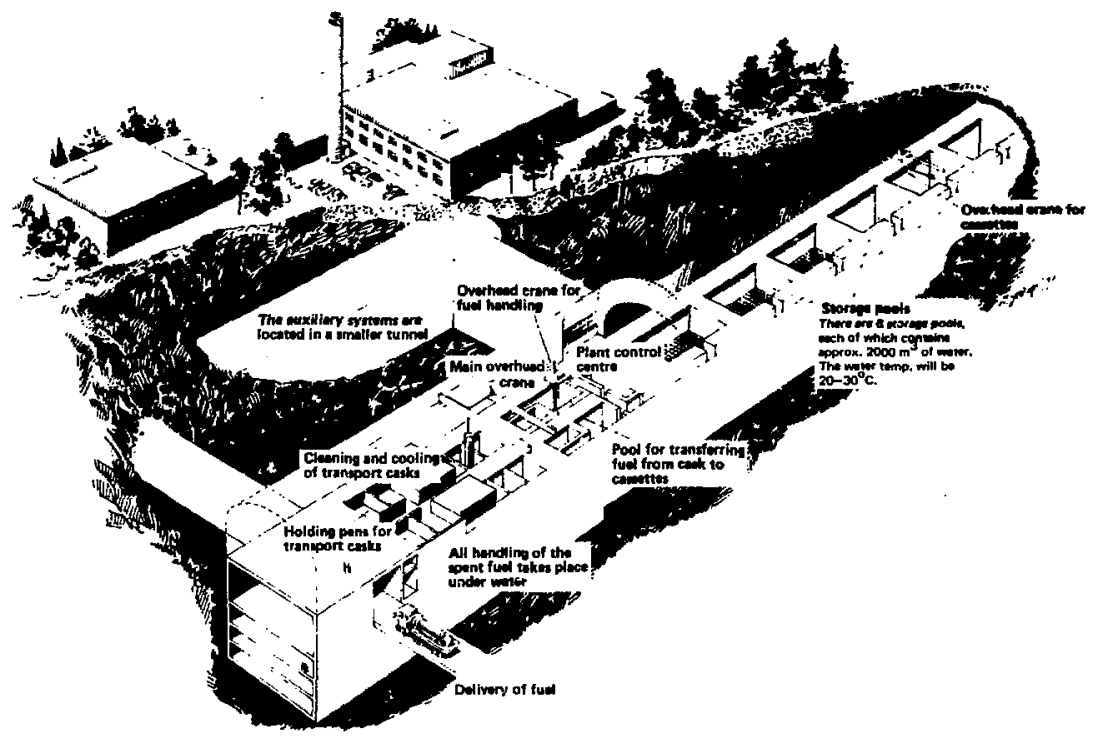

FIG. 4. Perspective drawing of the central storage facility for spent fuel.

of 3000 tonnes of SUP. The facllity will then be suscessively expanded as need arises. See also sectlons 2.9 and 3.1 .

\subsection{SELECTION OF FINAL STORAGE SITE (DEPOSITORY)}

Granite rocks belongling to the 600-million-year old Fennoscandian shield underlfe most of Sweden. Volcantsu has not occurred is the last 125 million years, and strong earthquakes are hlstorically unknown. The maximum magnitude ever recorded is around 5 (Rlchter scale). Some rather large areas bordering the Baltic sea seem to be completely free from earthquakes (greater than force 2) and are considered to belong to the world's most stable geologic areas.

The final depository, it is suggested, should be located in such an area, and at a depth of $2500 \mathrm{~m}$. It has been shown that dozens of ice ages have had no other effect at this depth than minor Inoreased fracturing. Bxtensive drilling has been carried out in 4 major areas, and geophysical and hydrological data collected, test drillings, are presently being done at 12 
other scattered locations (see section 3.1). In general, the rock is fractured, with several fractures per drilled meter, but the fractures are small (mm-Bize and smaller) and filled with chlorite or other clayish material. The distance between crush zones surrounding such fractured granite rock bodies is of the order of 100 meters. Particularly Intensive studies have been carried out at Stripa, see Section 3.2.

Groundwater flows through the fracture system. Because the groundwater table falls very slowly towards the sea level along the Swedish coast, very small hydraulic gradients (water fall per diatance) are encountered. This contributes to a slow velocity of the groundwater flow. Groundwater has been analyzed with regard to $\mathrm{pH}$, Eh (electrochemical, or redox potentlal), chemical compasition (over 20 constituents; see Table 1), age, flow rate (Table 5), etc. Thus, a very detailed knowledge of groundwater conditions has been acquired. This knowledge is necessary for determining the two essential parameters: corrosion, which may release radicactivity into the groundwater, and water flow, which may transport the radionuclides to water used by man.

Although the hydraulic conductivity, which determines flow rate itogether with the bydraulir gradient and rock porosity) varles considerably along Investigated bore holes, the value of $\sim 10^{-9} \mathrm{~m} / \mathrm{s}$ was selected by the RBS as typical and acceptable for a granite rock depository, Large scale measurements Indicate even lower values, and conseguently lower water flow rates. With "typlcal values" for the hydraulic parameters, the groundwater velocity becomes $0.1 \mathrm{~m} / \mathrm{Yr}$, and groundwater flow 0.211 ter $\cdot \mathrm{Xr}^{-1} \cdot \mathrm{m}^{-2}$. These values are used in the safety analysis, Section 2.7.

The chemlcal composition of Swedish groundwater (Table 4) does not vary very much and is usually of drinking quality. It does not contain any particularly corrosive 1ons. The pH is close to neutral. However, there is one particular property which merits special attention, and that is the water redox potential. Due to the very small amount of oxygen $\left(\mathrm{O}_{2}\right)$, and considerably larger amounts of divalent iron ( $\mathrm{Fe}^{2+}$ ), the redox potential turns out to be negative, see Table 6 . The effect of this is twofold: (1) The water will not be able to oxidize metals (used as canister material), and (2) most dissolved waste products will be in a low valency state. This dramatically Increases canlster lifetime and delays waste product migration to repositories of water used by man. This is further discussed in Section 2.7. As described In Sections 2.4 and 3.2, an extensive exploration 18 going on for finding and selecting sultable sites for the depository. Many places 
TABLE 4. Probable composition of grouncwater in crystalline rock at great depth, according to Rennerfelt and Jacks.

\begin{tabular}{|c|c|c|c|}
\hline Analysis & $\begin{array}{l}\text { Probable } \\
\text { range }\end{array}$ & $\begin{array}{l}\text { Iinimum } \\
\text { value }\end{array}$ & $\begin{array}{l}\text { Maximum } \\
\text { value }\end{array}$ \\
\hline Conductivity & $400-600 \mu \mathrm{s} / \mathrm{cm}$ & & 1100 \\
\hline $\mathrm{pH}$ & $7.2-8.5$ & & 9.0 \\
\hline $\begin{array}{l}\mathrm{rumO}_{4} \\
\text { consumption }\end{array}$ & $20-40 \mathrm{mg} / 1 \mathrm{lter}$ & & 50 \\
\hline$C O D_{\text {Mn }}$ & $5-10 \mathrm{mg} / 1$ iter & & 12.5 \\
\hline $\mathrm{Ca}^{2+}$ & $25-50 \mathrm{mg} / \mathrm{liter}$ & 10 & 60 \\
\hline $\mathrm{Mg}^{2+}$ & $5-20 \mathrm{mg} / 11$ ter & & 30 \\
\hline $\mathrm{Na}^{+}$ & $10-100 \mathrm{mg} / 11 \mathrm{ter}$ & & 100 \\
\hline $\mathbf{R}^{+}$ & 1-.5 $\mathrm{mg} / \mathrm{l} 1 \mathrm{ter}$ & - & 10 \\
\hline Fe-tot & $1-20 \mathrm{mg} / 1$ iter & & 30 \\
\hline $\mathrm{Fe}^{2+}$ & $0,5-15 \mathrm{mg} / 11$ ter & & 30 \\
\hline $\sin ^{2+}$ & $0.1-0.5 \mathrm{mg} / 11$ ter & & 3 \\
\hline $\mathrm{HOO}_{3}^{-}$ & $60-400 \mathrm{mg} / 11$ ter & & 500 \\
\hline$\infty_{2}$ & 0-25 mg/liter & & 35 \\
\hline $\mathrm{Cl}^{-}$ & 5-50 mg/liter & & 100 \\
\hline $\mathrm{so}_{4}^{2-}$ & 1-15 mg/1iter & & 50 \\
\hline $\mathrm{wo}_{3}^{-}$ & $0.1-0.5 \mathrm{mg} / 11$ ter & & 2 \\
\hline $\mathrm{po}_{4}^{3-}$ & $0.01-0.1 \pi g / 11$ ter & & 0.5 \\
\hline $\mathrm{F}^{-}$ & $0.5-2 \mathrm{mg} / 11$ ter & & 8 \\
\hline $\mathrm{SIO}_{2}$ & $5-30 \mathrm{mg} / 11$ ter & & 40 \\
\hline $\mathrm{HS}^{--}$ & $<0.1-1 \mathrm{mg} / 1$ iter & & 5 \\
\hline $\mathrm{NH}_{4}$ & $0.1-0.4 \mathrm{mg} / 11$ ter & & 2 \\
\hline $\mathbf{N O}_{2}$ & $<0.01-0.1 \mathrm{mg} / 11$ ter & & 0.5 \\
\hline $\mathrm{o}_{2}$ & $<0.01-0.07 \mathrm{mg} / 1 \mathrm{iter}$ & & 0.1 \\
\hline
\end{tabular}

The estimated probability that a value will fall between the minimum value and maximum value ia $95 \%$. Higher values occur locally. 
TABLB 5. Hydrological conditions at 500 m depth in swedish granite bedrock.

\begin{tabular}{ll}
\hline $\begin{array}{l}\text { Average age of groundwater } \\
\text { Average velocity of groundwater }\end{array}$ & $3500 \pm 1000 \mathrm{Yr}$ \\
Groundwater flow: & $0.1 \mathrm{~m} / \mathrm{Yr}$ \\
$\quad$ Average & $0.211 \mathrm{ter} \cdot \mathrm{Yr}^{-1} \cdot \mathrm{m}^{-2}$ \\
$\quad$ Karlshamn & $0.00211 \mathrm{ter} \cdot \mathrm{yr}^{-1} \cdot \mathrm{m}^{-2}$ \\
Hydraulic conductivity: & \\
Common range & $10^{-7}-10^{-11} \mathrm{~m} / \mathrm{s}$ \\
Average & $10^{-9} \mathrm{~m} / \mathrm{s}$ \\
Rarlshamn & $2 \times 10^{-12} \mathrm{~m} / \mathrm{s}$ \\
Stripa mine & $2 \times 10^{-11} \mathrm{~m} / \mathrm{s}$ \\
\hline
\end{tabular}

TABLE 6. The redox potential in deep groundwater from Precambrian Swedikh bedrock, according to Grenthe.

\begin{tabular}{rlr}
\hline Sample No. & \multicolumn{1}{c}{ Site } & Eh (mV) \\
\hline 7 & Stripa & -152 \\
8 & Stripa & -31 \\
18 & Stripa & -173 \\
19 & Pinnsjö area & -191 \\
21 & Stripa & -210 \\
14 & Stripa & -26 \\
20 & Finnsjö area & -157 \\
24 & Stripa & -140 \\
\hline
\end{tabular}

will be investigated, to provide a number of site options, because it is believed that only few places will not be met by public opposition.

2.5 DISPOSAL OF ULREPROCESSED SEENT FUEL ELEMENTS

The varlous steps of the aisposition of unreprocessed spent fuel elements are shown diagraumatically in Fig 5.

After 40 years in the Central Fuel storage Facility (CrAB), the fuel is transported to an encapsulation station. The method of transportation is Identical to that used to transfer the fuel from the power station to the CLAB. 


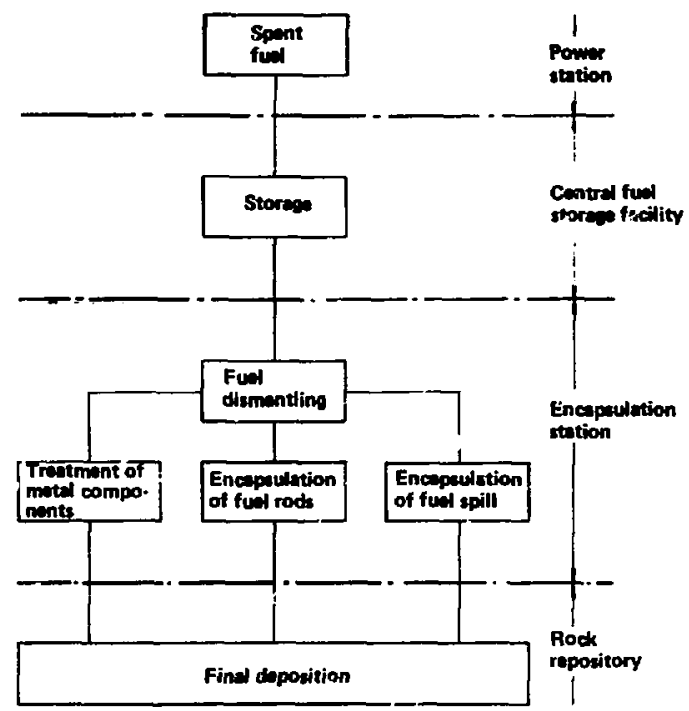

FIG. 5. Flow schewe lllustrating the handling chain for the spent fuel from the power station to the final repository.

The encapsulation station, which is shown in successively increasing detail in Figs. 6, 7, and 8, is situated above ground, connected with the final depository. In the encapsulation station the fuel is dismantled, separating the fuel rods from metal components of the assemblies. The fuel rode are enclosed in copper canisters with walls $200 \mathrm{~mm}$ thick. (See Figs. 9 and 10.) Each container weighs about 16 tonnes and can hold 500-640 rods, depending on the type of fuel. The space between the fuel rads is filled with lead. Fuel spill from handling of the fuel assemblies is encapsulated in a similar manner.

The copper canisters are transferred to a final depository arproximateily $500 \mathrm{~m}$ down in the bedrock. It is proposed to design the depository as a system of tunnels $25 \mathrm{n}$ apart (ste Fig. 11), with storage holes drilled in the floor. The holes will be $6 \mathrm{~m}$ apart, $7.7 \mathrm{~m}$ deep, and $1.5 \mathrm{~m}$ in diameter, (see Pigs. 11-15). The canisters will be placed on and surrounded by precompacted bentonite. This material will grvell during water uptake, filling fractures in the surrounding rock. To contain the swelling pressures the 


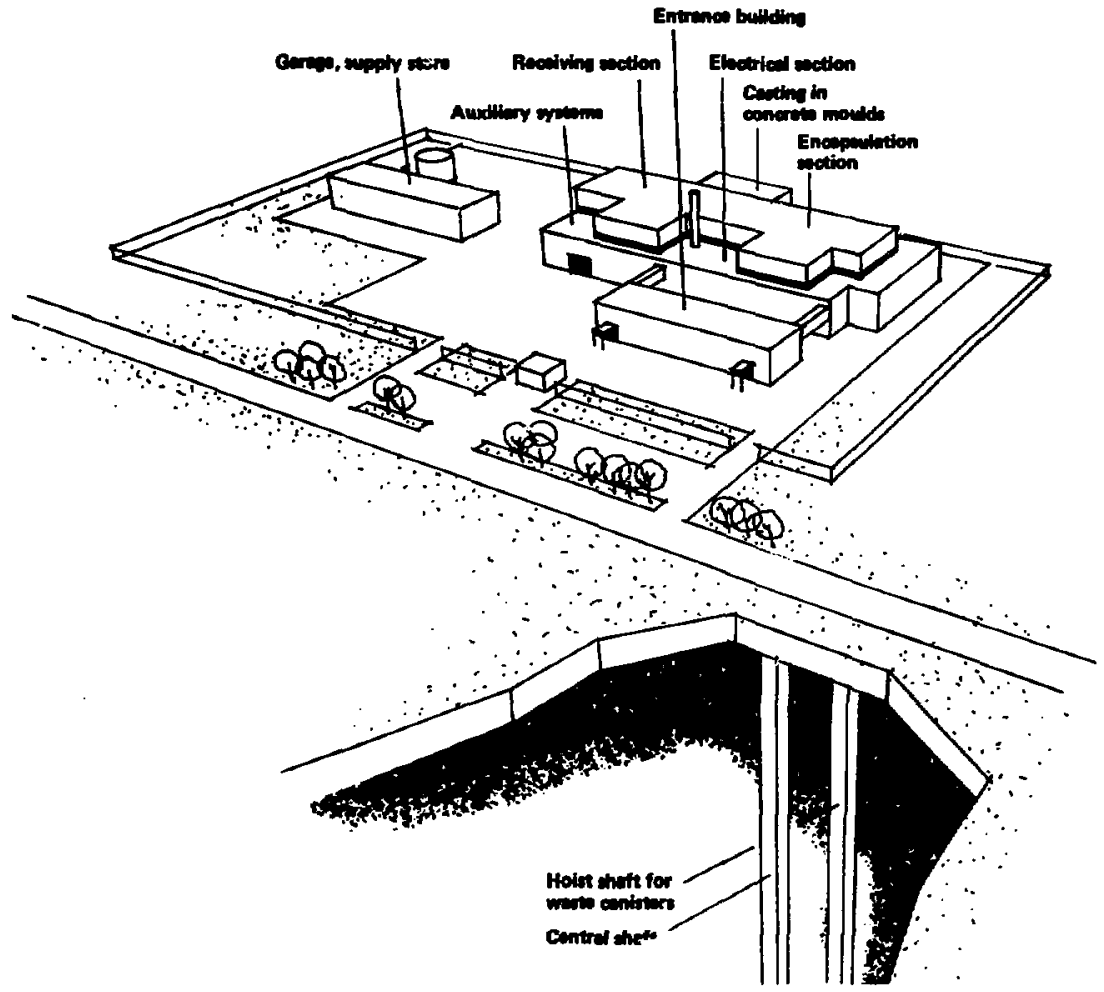

FIG. 6. Encapsulation station for spent nuclear fuel. The fofility is - located at ground level above the final repsitory.

holes will be plugged at the top with a concrete bax. The bentonite also acts as an elastic support, allowing considerable movement of the surrounding rock without damaging the canister. The bentonite also has a very low water permeability, $10^{-12}-10^{-14} \mathrm{~m} \cdot \mathrm{s}^{-1}$. Further, the bentonite has Ion-exchange properties, leading to a retention of lons eventually migrating through the bentonite. After the canisters have been deposited, and the holes filled with bentonite, the tunnels will be filled with a bentonite-quartz mixture (Figs. 14 and 15). Since the dose rate of the canlster gurface at the time of deposition is $\leq 1$ rem/h (Fig. 16), the deposition operation can be carried out without excessive remote-handling equipment. 


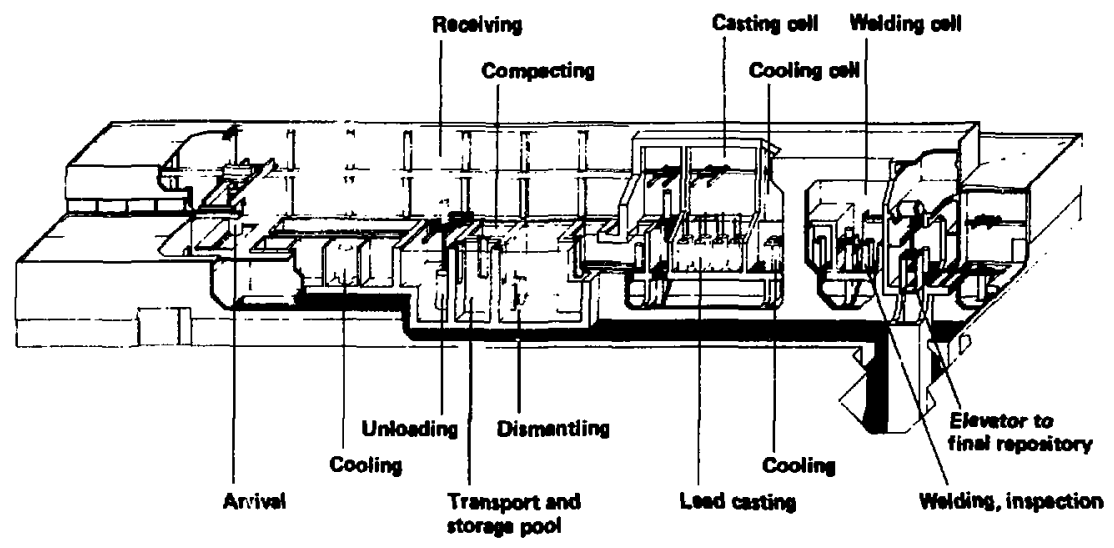

FIG. 7. Perapective drawing of encapsulation station's process building.
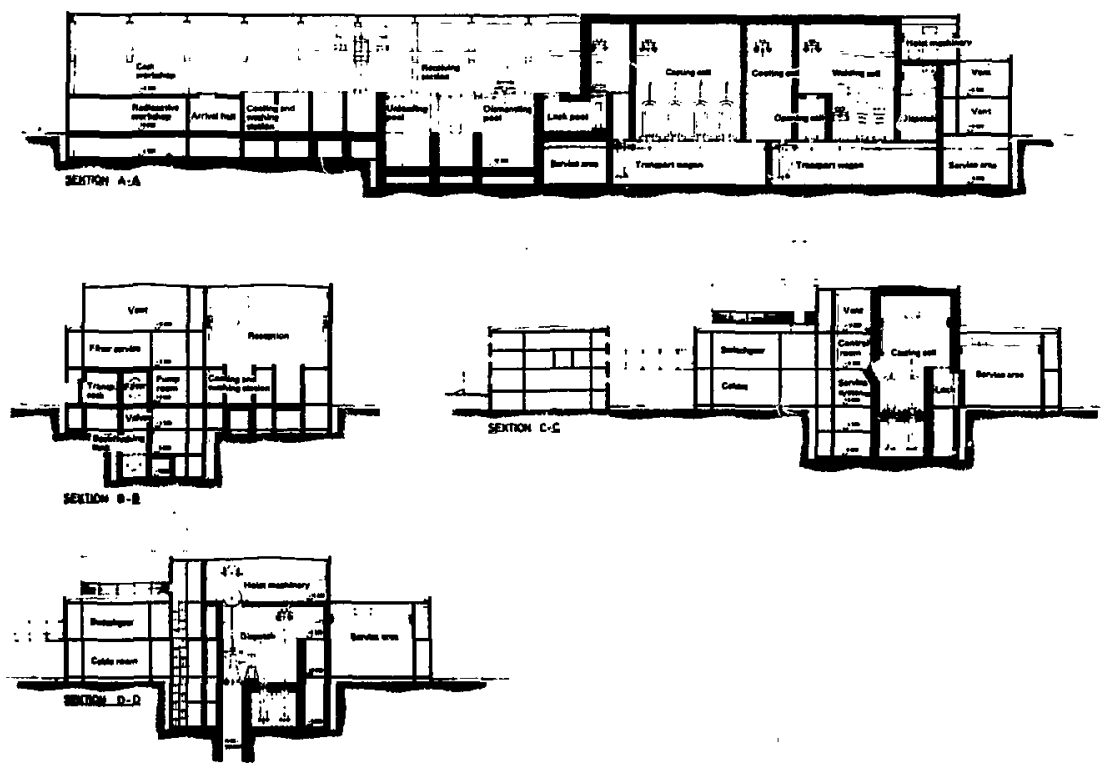

FIG. B. Building layout of encapsulation station. 


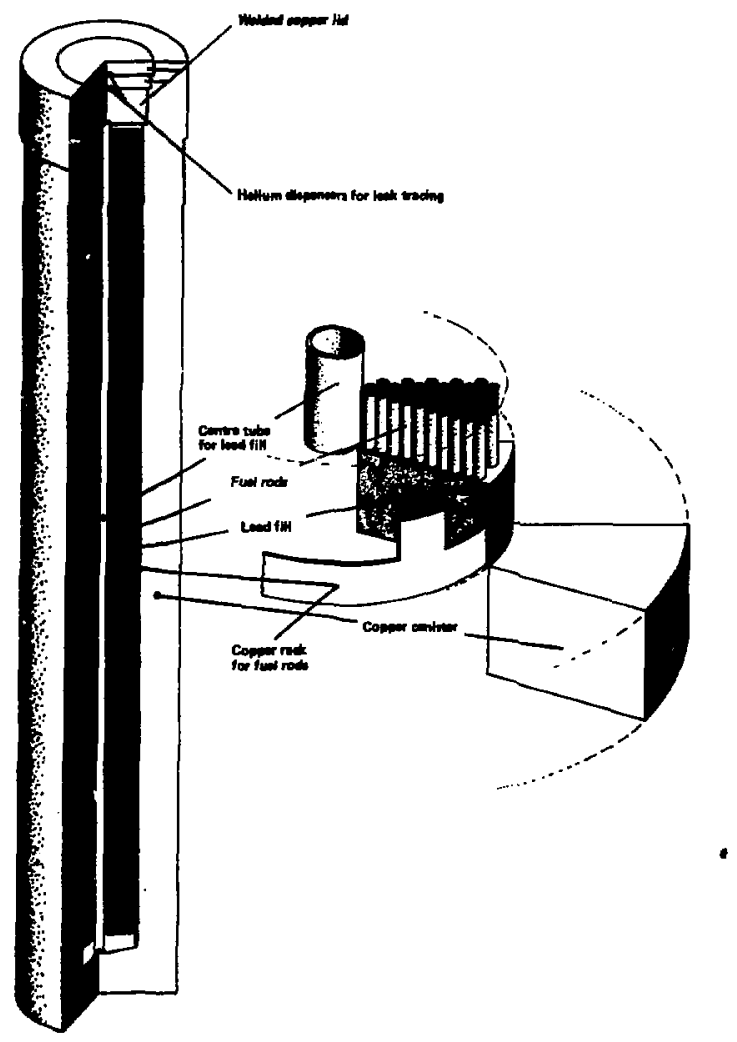

FIG. 9. Cutaway drawing of copper canister filled with fuel rods. After dismantling of the fuel assemblies, the fuel rods are placed in a cylindrical rack whose perforated copper shell encloses the fuel rods. The filled rack is covered with a perforated $11 d$ and lowered into the canister. The center tube is used for lifting and lead casting. 


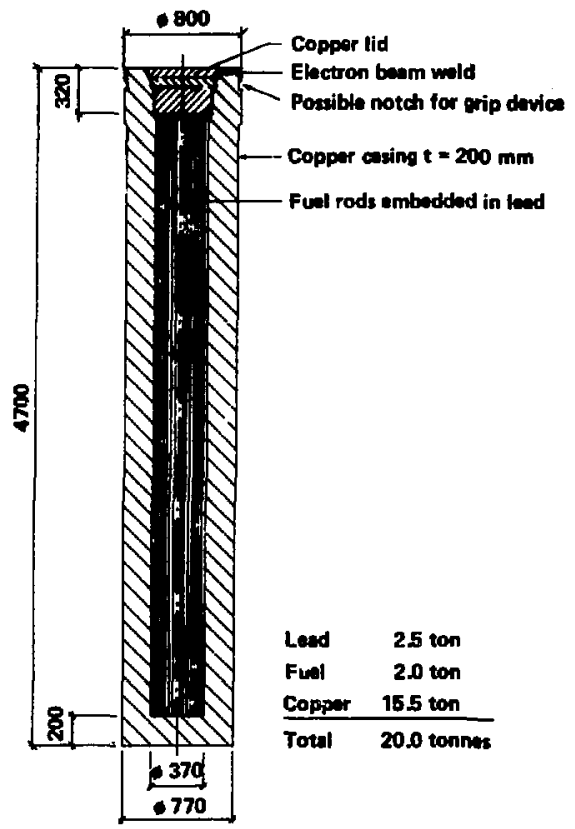

FIG. 10. Longitudinal section of copper canister with fuel rods erbedded in lead (dinensions in $\mathrm{mm}$ ). 


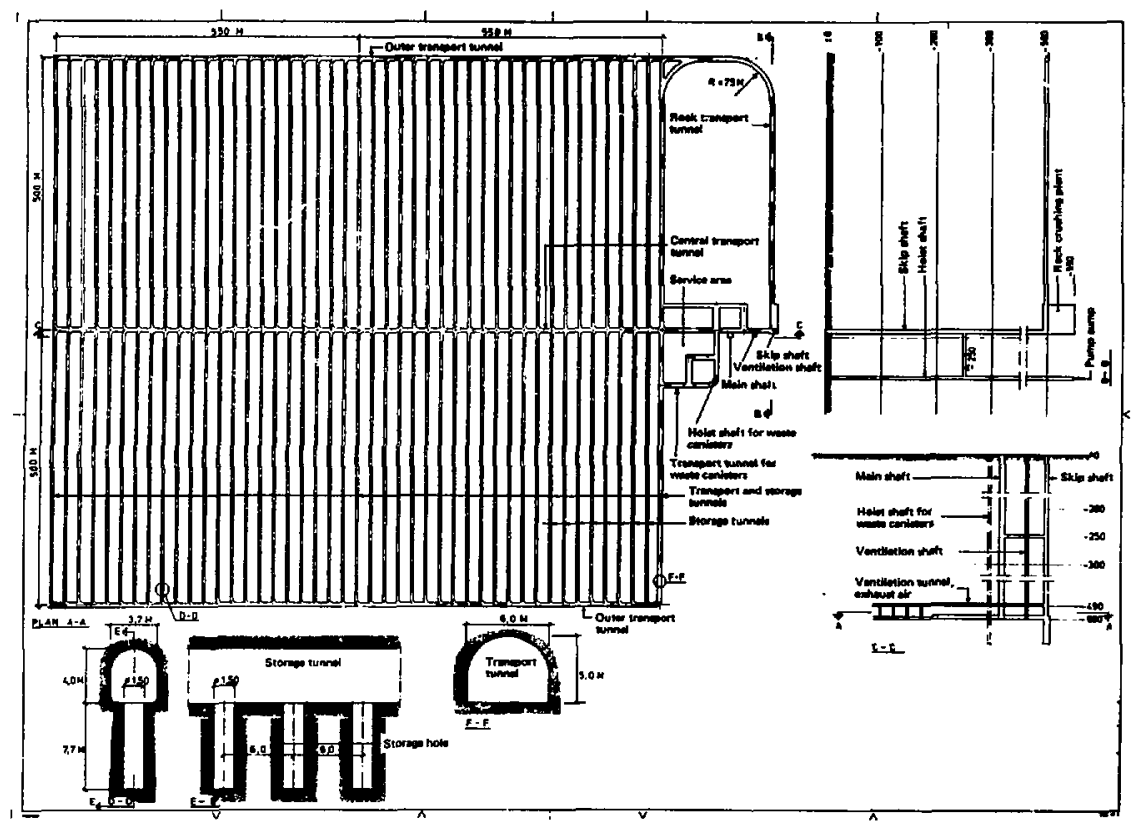

FIG. 11. Layout of final repository. 


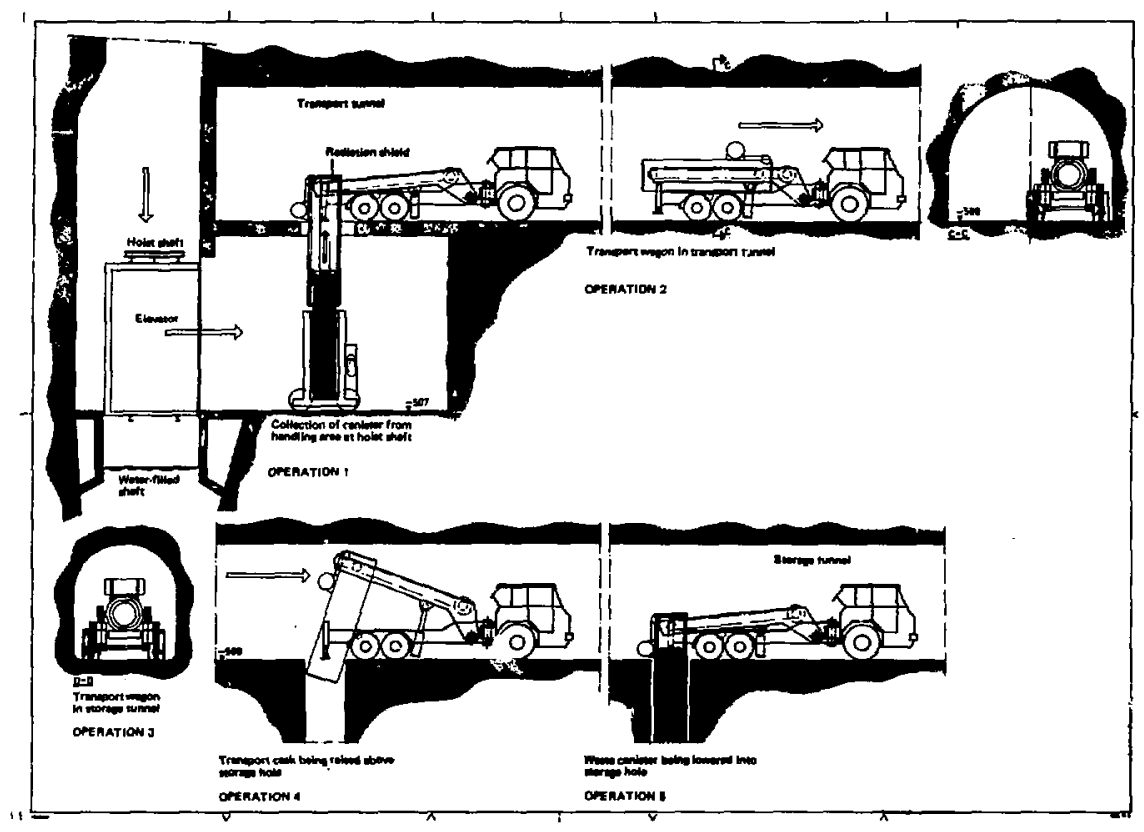

FIG. 12. Transport and deposition of waste caniater in final repository. 


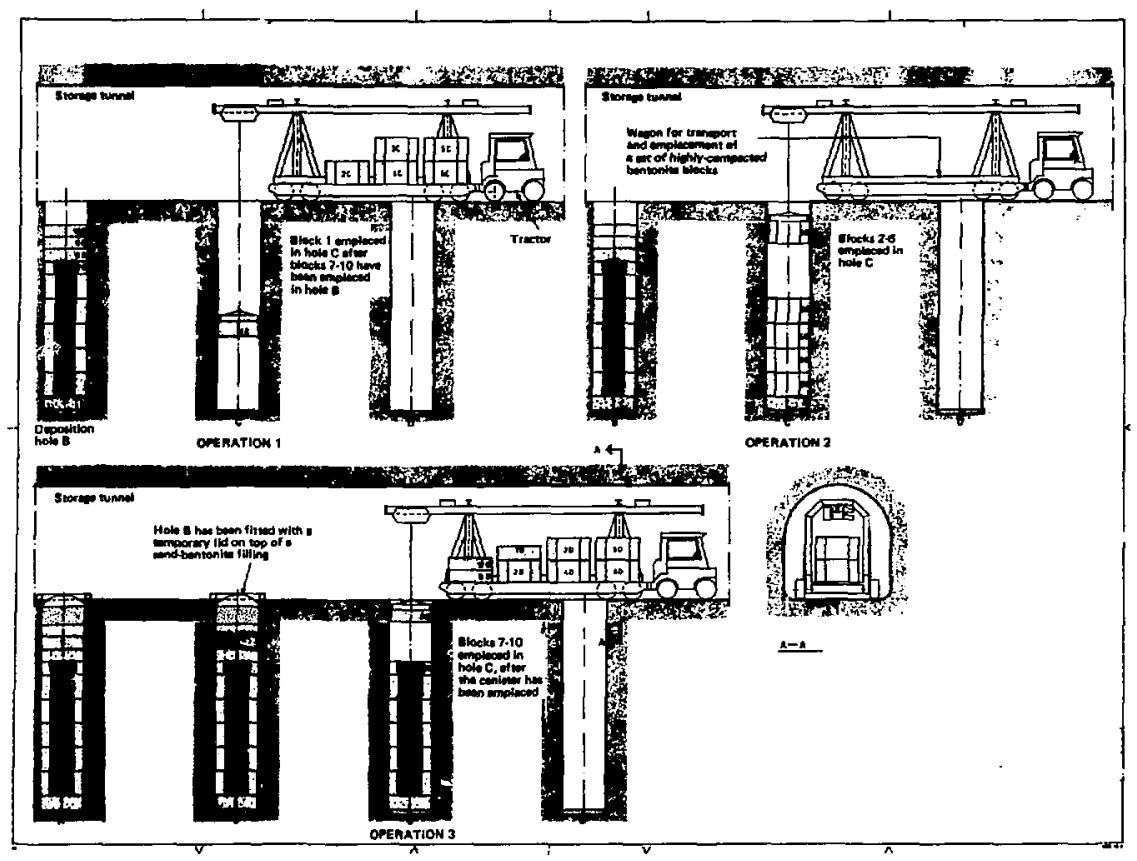

FIG. 13. Buplacement of bentonite blocks in storage holes.

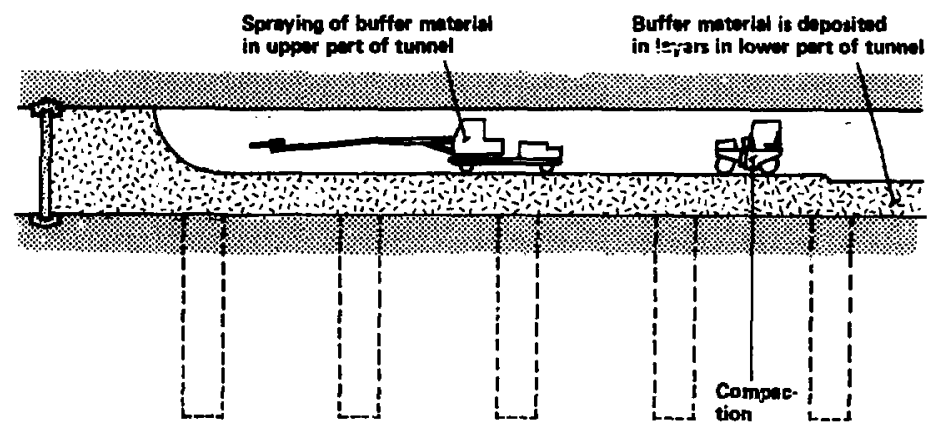

PIG. 14. When the final repository is sealed, the tunnels are filled with a mixture of quartz-sand and bentonite. The lower part of the fill is deposited by tractors and vibrorolled. The upper part of the tunnel is filled by spraying. 


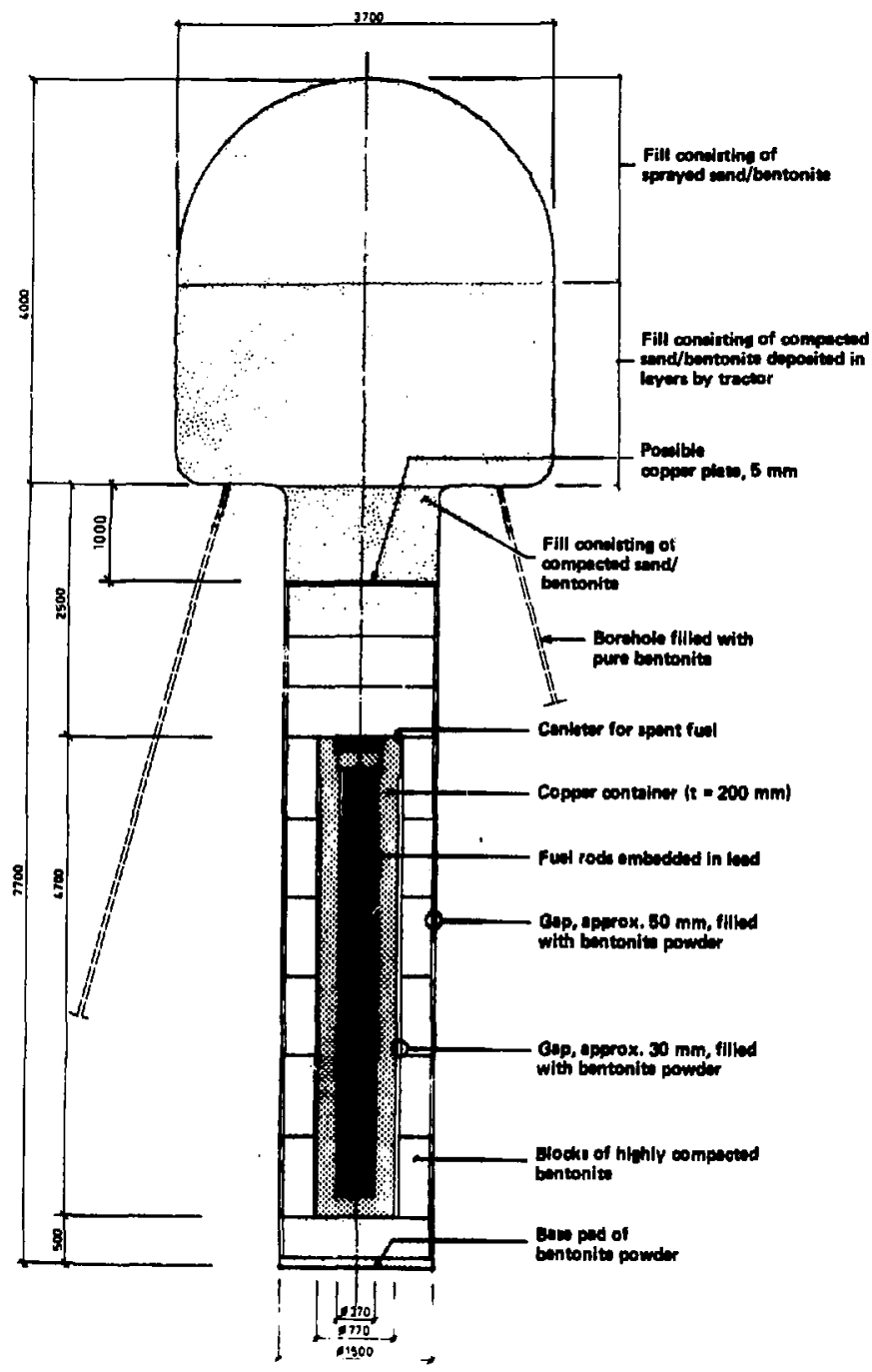

FIG. 15. The sealed final repository. The cantster is surrounded in the storage hole by highly compacted bentonite. The gaps are filled with bentonite ' powder. The tunnel is fliled with mixture of quartz-sand and bentonite. A copper plate can, if deaired, be placed on top of the bentonite block to serve as a diffusion barrier. Dimensions are in $\mathrm{mm}$. 

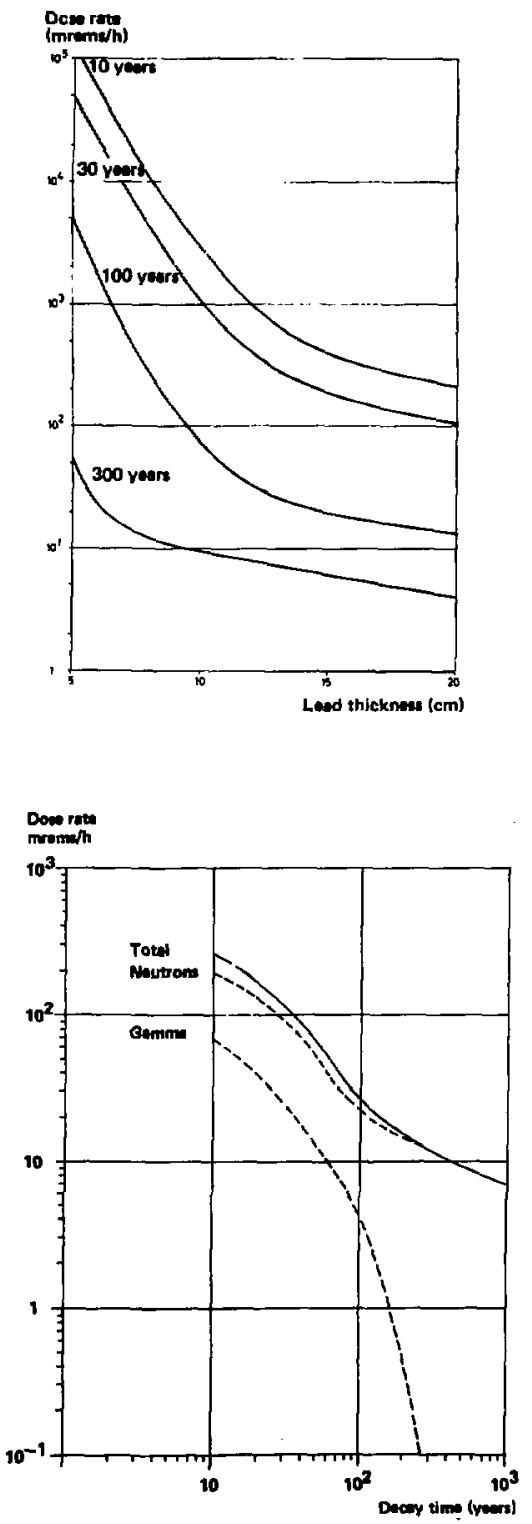

FIG. 16a. Total dose rate from gamma radiation and neutrons on the outside of encapsulated vitrified waste from presaurized waste reactoro at different lead thicknesses.
FIG 16b. Radiation dose rates on surface of copper canister after different decay times. 


\subsection{HANDLTNG OP REPROCESS TIG WASTE}

The various steps of the reprocessing cycle are shown in Fig. 3a. After about 20 years of storage in the CLAB, the spent fuel elements are transported to a reprocessing plant abroad (the Swedish Fuel Supply Company has contracts with the French Company Cogema and British Nuclear Fuels Ltd.), where uranium and plutonlum are removed and the high-active waste is vitrified and returned to Sweden. Each canister of vitrifled waste will contain about 92 fission products and about 18 of actinides in $420 \mathrm{~kg}$ borosilicate glass of the French AVM type in a stainless steel (3 mm) canister. Bach canister will contain the high-actlve waste fram reprocessing 1 tonne spent fuel (Table 2).

The canisters will be returned to sweden and stored in an Intermediate storage Facility (ISF) located underground directly connected with the final depository. See Figs. 17 and 18. Because of French experience, these canisters will not be water-cooled but air-cooled. Cooling redundancy is achieved by having four cooling fans, two at the storage vaults, one in reserve nearby, and one in reserve at the ground level. The motors are powered from an electricity grid and have energency diesel generators as well. Figures 19 and 20 ahow various sections of the ISF and 1 ts pentilation system. If all fans fall, natural convection is oufficient to prepent destruction of the canisters. The heat power of a canister is about $2 \mathrm{~kW}$ at $10 \mathrm{yr}$, and about $0.5 \mathrm{~kW}$ at $40 \mathrm{Yr}$.

About 40 years after reactor discharge, the canisters with the vitrified wate are transferred to the encapsulation station (Fig. 18) and surrounded by $10 \mathrm{~cm}$ of lead and an outer container of $6 \mathrm{~mm}$ titanium. Lead was chosen because of its high radiation-shielding capacity and titaniug because of its corrosion resistance, even in salt waters. Flgure $2 I$ shows the recapped vitrified waste canister in the final depository. Its welght is about 4 tonne (Table 2) and the radiation level on its surface is slightly below 1 rea/hr (Fig. 16a).

The recapped canisters are transferred to the final depository about $500 \mathrm{~m}$ below the ISF in the granite bedrock. The final depository is designed as for the apent fuel elements, though the holes drilled in the tunnel floors are smaller (diameter $l \mathrm{~m}$, depth $5 \mathrm{~m}$ ) and closer (4 m apart). The deposition and filling technique is illustrated in Fig. 22. The vitrifled waste canisters are surrounded by a bentonite buffer. 


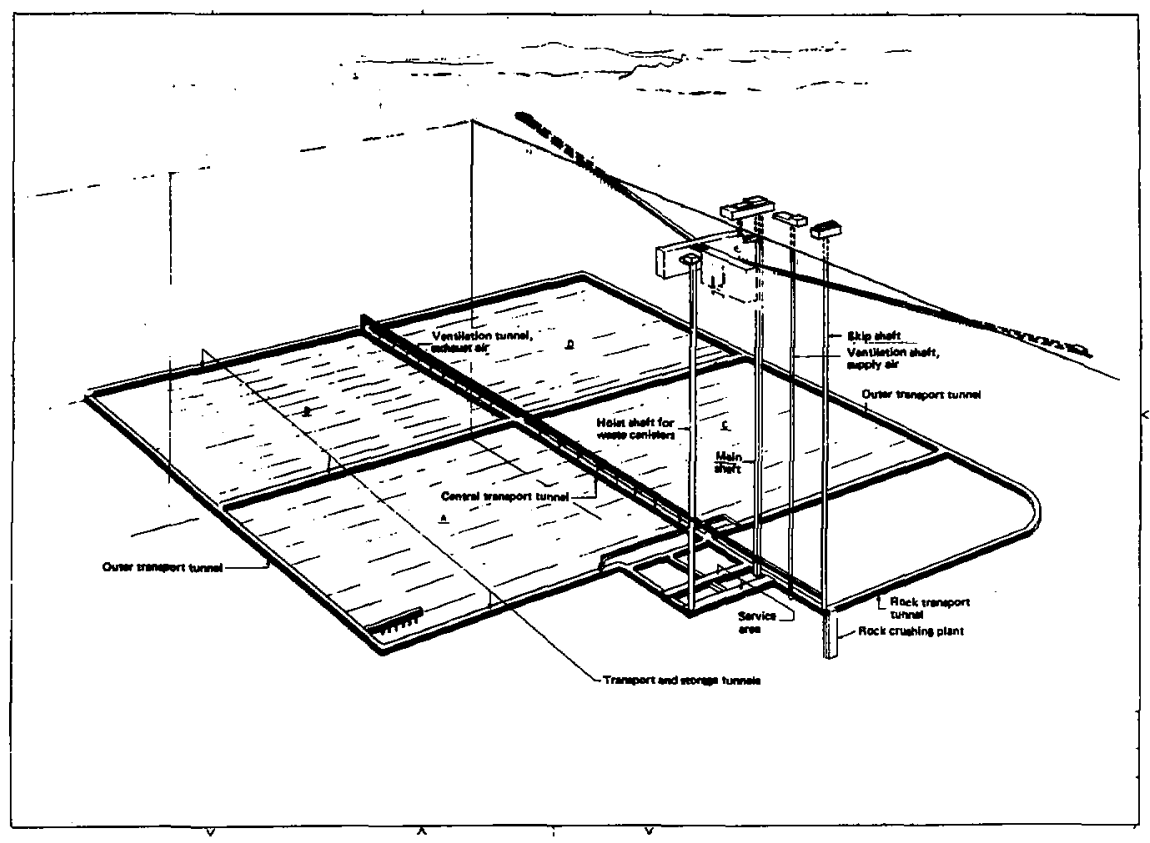

FIG. 17. Perspective drawing of final repository. 

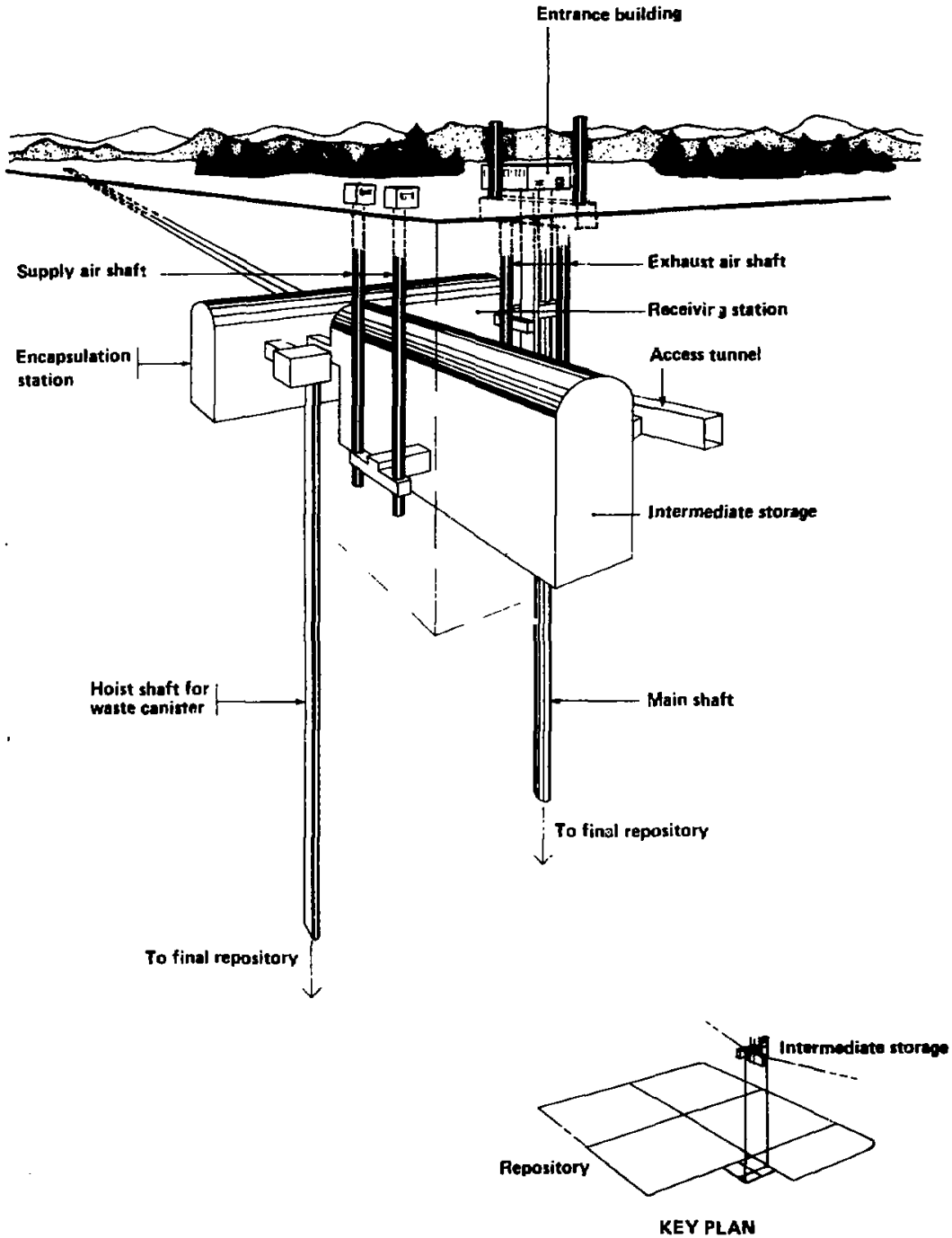

FIG. 18. Perspective drawing of plant for Intermediate storage and encapsulation. It is located underground with a rock cover ipproximately 30 m thick. The plant is located above the final repository. 


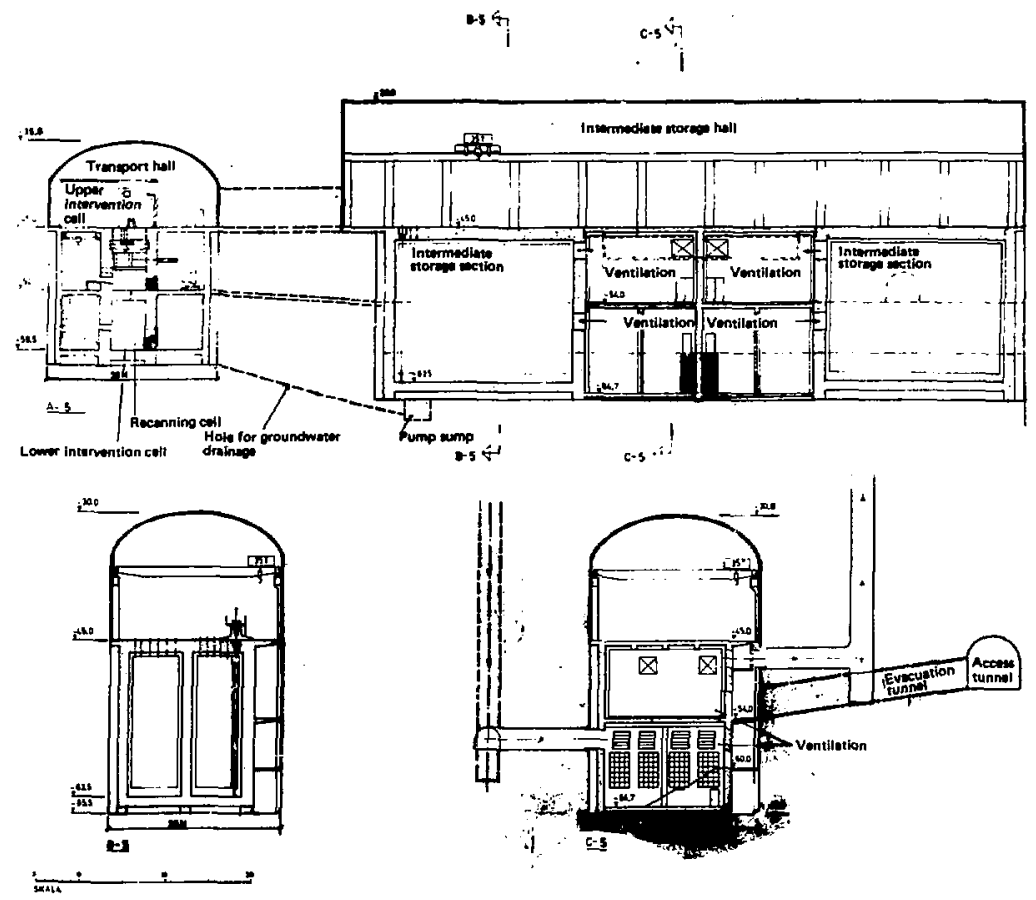

FIG. 19. Longitudinal section and cross sections of intermediate storage and encapsulation plant (cf. Fig. 18). 


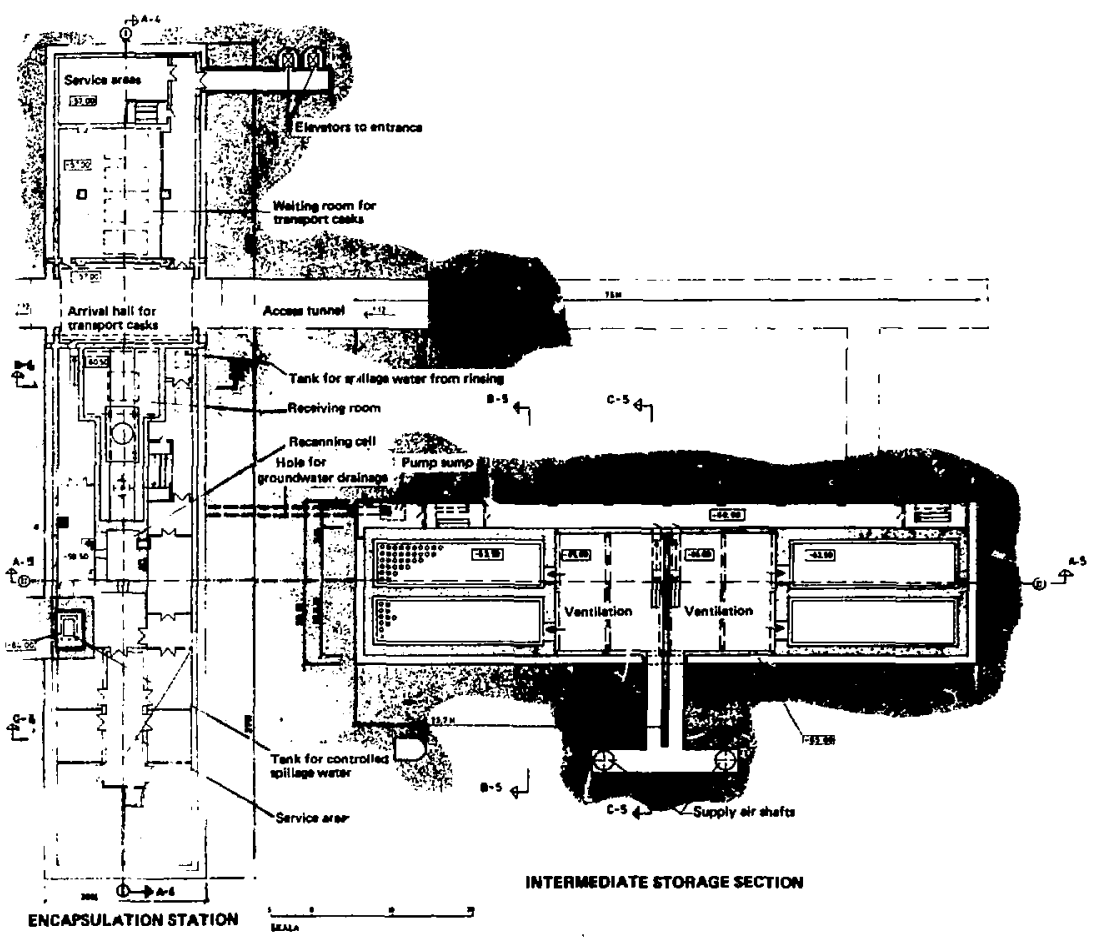

FIG. 20. Intermediate storage and encapsulation pIant. 


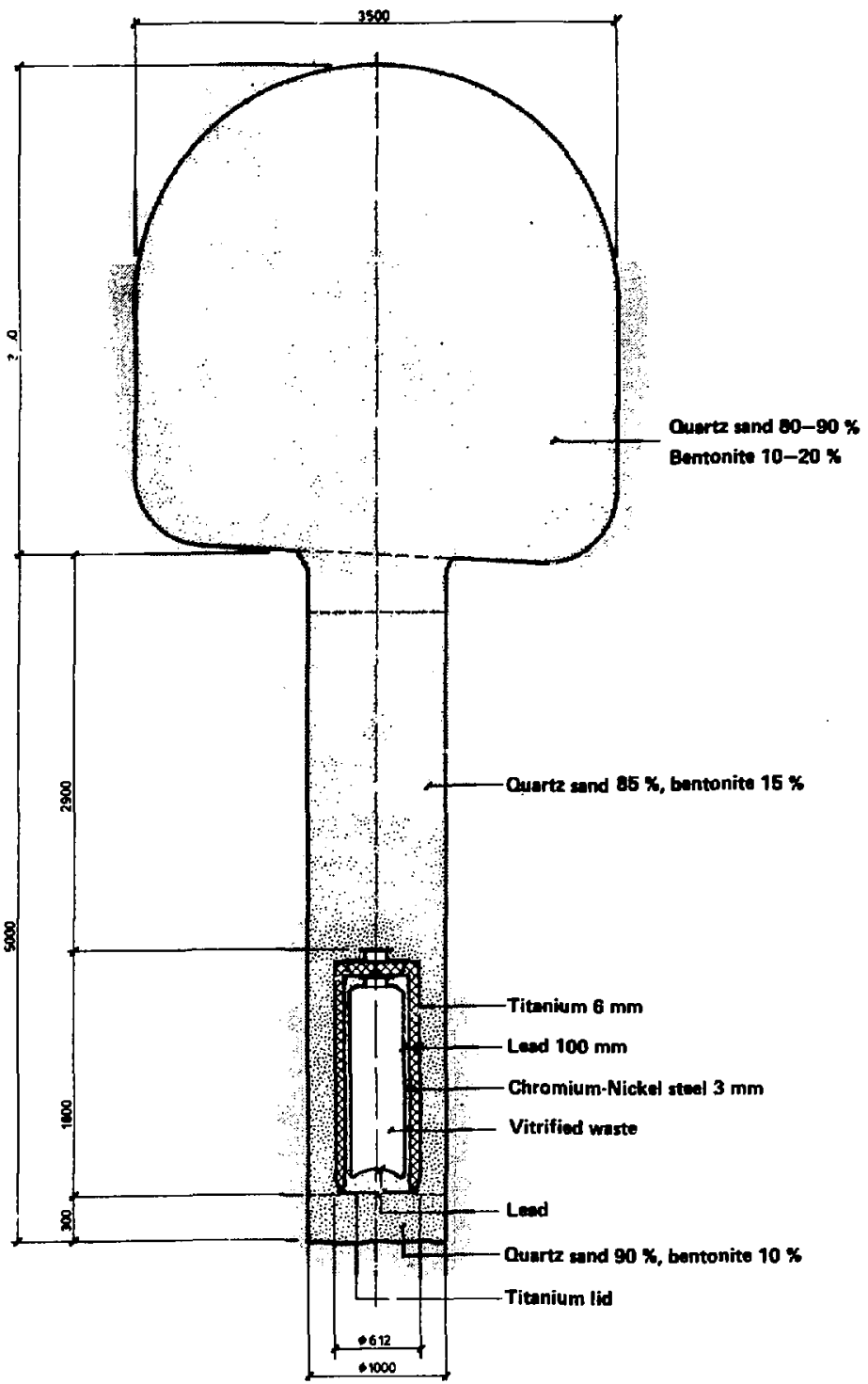

FIG. 21. Bealed final repository. Dimengions are in ma. 


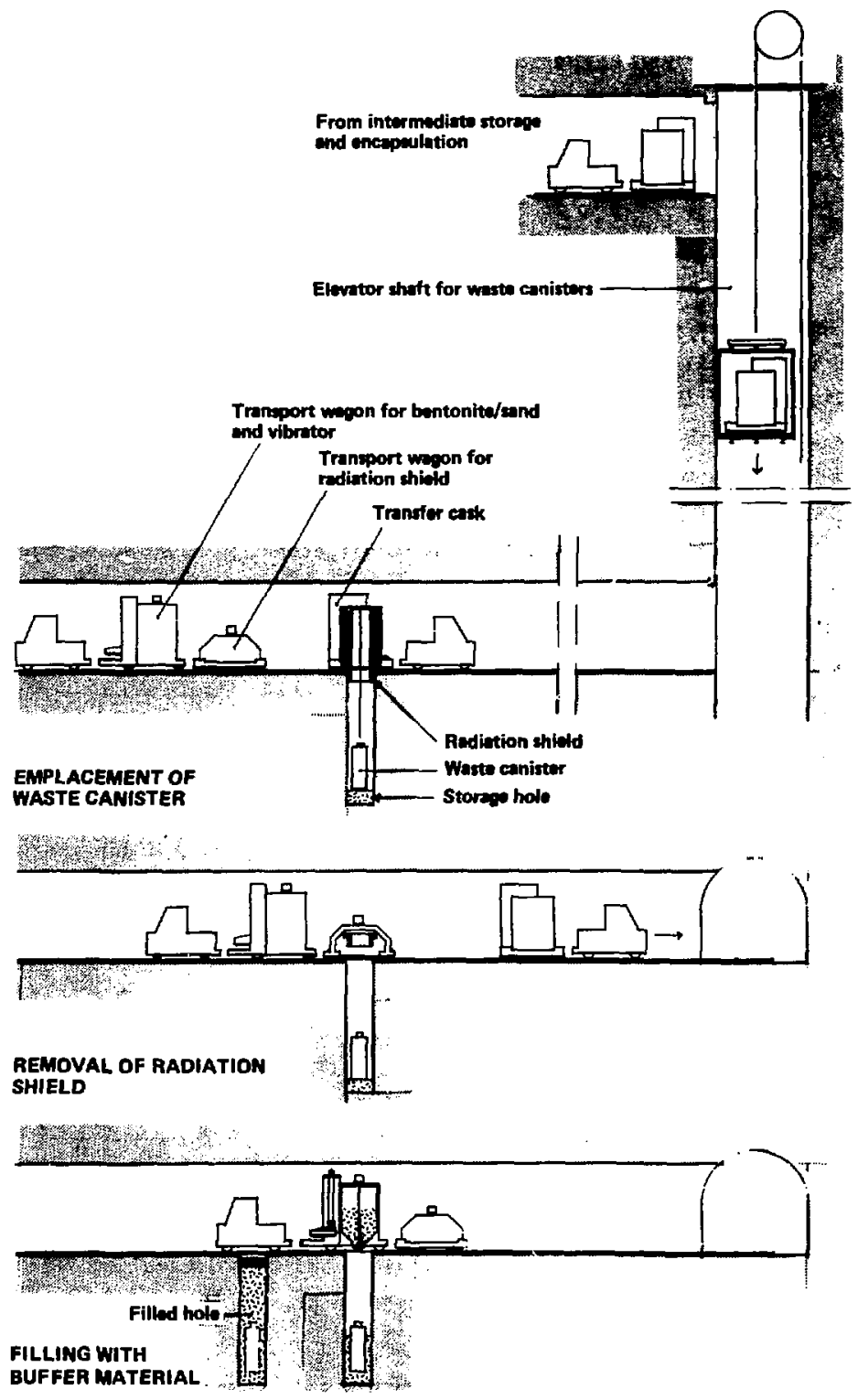

PIG. 22. Handing of waste canisters in final repository. 
Safety in the handling, transportation, and intermediate storage has been Investigated through fallure analysis. The data are too detalled to be reviewed here, but as a general conclusion one can bay that no area of excessive risk has been ldentifled.

\subsection{SAFETY ANALYSIS OF THE FINAL DEPOSTTORY}

Although a great number of risks are encountered in the handling chain from the removal of the spent fuel elements from the reactor until the waste is disposed of in the final depository, these risks are not very different from those which man encounters in the dally work with radioactive naterials. Also the risks are encountered over a short time, and normally can be rapldiy corrected for, covering altogether a human "lifetine" of 50-70 years. The rlok from the final depository is quite different: it "appears" only after the depository is closed, when the possibilities for discovery are amall and for correction alnost $\mathrm{nil}$, and it will last for "aillenia." Therefore, the risk from the raste in the closed depository mat be made much onaller than the rlaks in the preceding handling chaln.

In order to meet this requirement, the KBS relies on a number of. barriers, of which three are man-made and one is natural, each being in princlple independent of the others:

1. A pooriy dissolvable natrix $\left(\mathrm{DO}_{2}\right.$ or glass) containing the waste.

2. A number of corrosion-resistant metallic barriers (lead, copper, titaniun).

3. An elastic clay buffer, which also acts as a water and radionuclide barrier.

4. Rock retention, slowing down the radionucilde movement.

The long-term stability and reliabllity of each of these barriers have been analyzed by KBS, and are surmarized below.

\subsubsection{Geology and Bydrology}

The aBs concludes that the geological and hydrological conditions are stable and will remain stable for a Swedish granite wate repository for

\footnotetext{
However, keeping the waste depository tunnels open and using groundwater radiation detectors, would allow for corrective measures if needed.
} 
nillenia (Section 2.4). Nost of the critics of the KBS profect have addressed this point. Though a majority of the geologiats reviening the res project support the kBS conclusion, sone geologists have comented that "geology is a descriptive sclence, not a predictive." Wile the long-tecm atability of the depository area is a matter of belief in extrapolations from past stability data, the continuing hydrogeologic studies indicate that groundwater woves more slowly than is asauned for kas main case (hydraulic conductivities close to $10^{-11} \mathrm{~m} / \mathrm{s}$ rather than the value $10^{-9} \mathrm{~m} / \mathrm{s}$ assumed by $\mathrm{kBS}$ ). Th1s adds an extra safety margin to the hydrogeological assumptions. However, as scme critics have pointed out, determination of groundwater age is extremely complicated, and the results are therefore subject to doubt. Ongoing research in this field is of utmost importance for the safety analysis, and for public trust.

\subsubsection{Radiatjon Effects}

Experiments with radiation doses higher than will be encountered in reality show that the canister materials will be unaffected by the radiation from the radioactive waste nuclides. The heavy radiation shlelding (copper and lead) reduces the radiation doses at the canister surface to such low levels that radiolysis of water and radiation effects on the clay become negligible. Experiments and careful calculations show that no radiolysis gases $\left(\mathrm{H}_{2}\right.$ and $\left.\mathrm{O}_{2}\right)$ will appear.

\section{7 .3 Heat Effect}

The small amount of waste in each canister, the long cooling times, the large canister surface areas, and the space distribution of canisters in the depository (producing $<5 \mathrm{w} / \mathrm{m}^{2}$ flooi area) all contribute to the $10 \mathrm{w}$ canister surface temperature (maximum $75^{\circ} \mathrm{C}$ ) and mean rock temperature (maximum $60^{\circ} \mathrm{C}$ ) shown in Fig. 23. The moderate surface temperatures guarantee the stability of the clay buffer and chemical interactions between groundwater and canister materials are not greatly accelerated at these temperatures. Strips experiments show that the tenperature increase does not lead to excessive fracturing but lowers the hydraulic conductivity. 


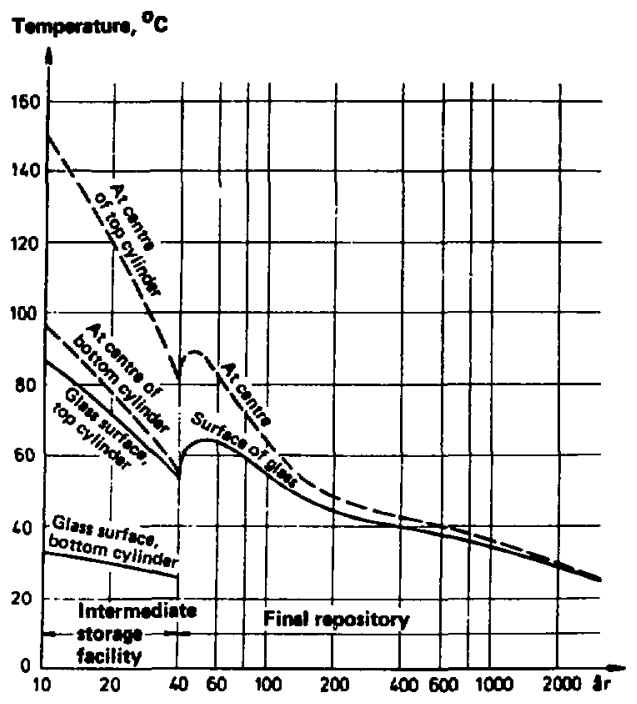

Time after dischares from resctor, years

FIG. 23a. Temperature of the vitrifiad waste in the intermediate storage facility and the final repository.

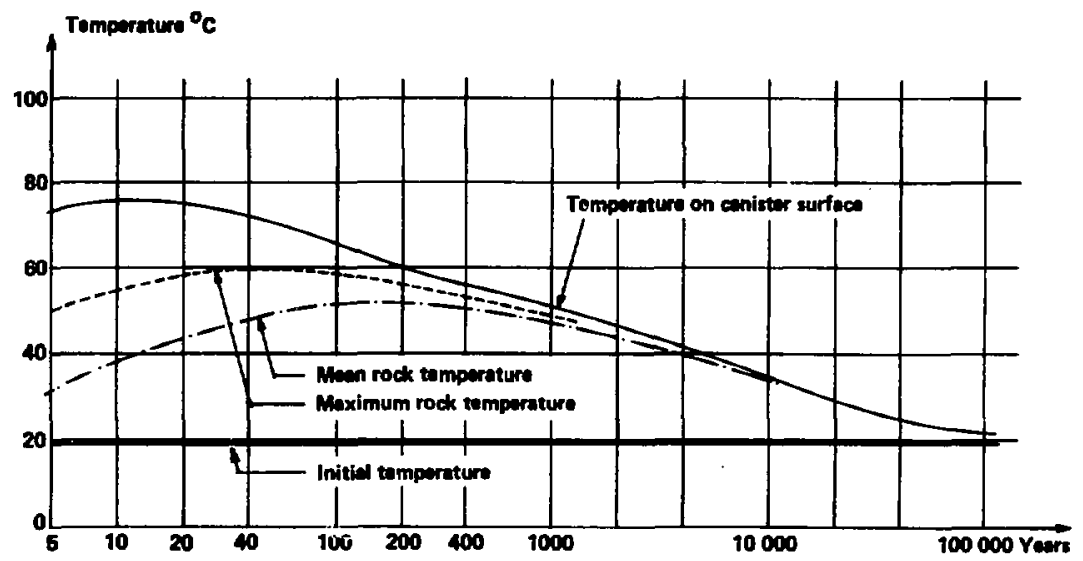

Time after deposition in finel repository

FIG. 23b. Temperatures on canister surface and in rock at different points in time after deposition in final repository. 


\subsubsection{Disgolution Rates}

Table 7 summarizes the dissolution times calculated by RBS for the canisters from the two waste chains. The calculations are based on experimental corrosion rates at relevant temperatures, for water which is as similar as possible to typical groundwater. The dissolution time for the glass is a particularly controversial 1ssue, because the rate of aissolution strongly dependa on glass composition, groundwater composition, and temperature. Also, dissolution of most glasses becomes nuch slower as time passes. In an experiment, the leaching rate of strontiue $\left({ }^{90} \mathrm{sr}\right.$ ) from a Canadian glass went from $\sim 10^{-7}$ down $t::^{-10} \mathrm{~g}^{\circ} \mathrm{cm}^{-2} \cdot \mathrm{d}^{-1}$ in about 10 years. (The first measurement was in the laboratory and the second was in a ffeld test.) The kBS uses a value of $2 \times 10^{-7} \mathrm{~g}^{*} \mathrm{~cm}^{-2} \cdot \mathrm{d}^{-1}$, which would dissolve the glass in 3000 years. Experience indicates that this is a highly conservative value.

In order to dissolve a metal, there must be an oxidant as well as a sufficient amount of water, also, complexations can increase solubility. All these factors have been taken into account: it is observed both that the amount of oxidants (mainly $\mathrm{O}_{2}$ ) in deep groundwater is small (see also next section) and that the amount of $g$ : oundwater itself 18 small (about $2.3 \mathrm{~m}^{3} / \mathrm{yr}^{2}$ for the copper canister hole), leading to very long dissolution times for the metals copper and lead. (For groundwater containing $0.1 \mathrm{ppra} \mathrm{O}_{2}$ (see

TABIE 7. Calculated cantster dissolution times (yr).

KBS-I:

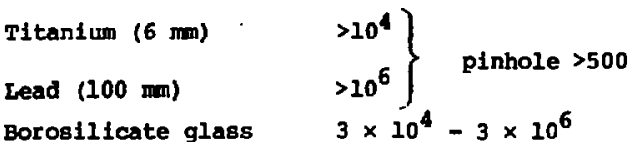

XBS-II:

$\begin{array}{ll}\text { Copper (200 min) } & >10^{6} \\ \text { Lead (intergtitial) } & \text { not accounted for } \\ \text { zircaloy }(\sim 1 \mathrm{~m}) & \text { not accounted for } \\ \text { Uranium dioxide } & \sim 10^{6} \text { (carbonate complex) } \\ \text { Alumina (corundum) } & >10^{4}\end{array}$


Table 4), and becauge $1 \mathrm{~g} \mathrm{O}_{2}$ can oxidize only $4 \mathrm{~g} \mathrm{Cu}$, and the fact that a canlster contains 15 tonnes $\mathrm{Cu}$, the dissolution time would be $15 \times 10^{9} / 10.1$ $\times 4 \times 2,3 \times 10^{3}$, $=16$ million years, if each oxidation leads to dissolution.)

A criticiam of the RBS disBolution times is that the chemistry is more complex in practice than KBS assumes from stmple idealized experiments. For example, special types of corrosion can leas to earlier penetration of barriers. On the other hand, studies of old archeological objects and volcanic and meteoritic glasses indicste that corrosion rates could be slower than KBS assumes. Since dissolution rates depend on groundwater composition and flow rate, they will be highly site-specific.

\subsubsection{Radionuclide Transport Throuch the Ground}

Once dissolved, radionuclides will move with the groundwater velocity, if they do not sorb on the rock fractures carrying the groundwater. Experiments Initlated by KBS and carried out elsewhere show that most radionuclides gorb on granite rocks. The sorption depends on the chenletry of the nuclide and of the groundwater. The efiect of the sorption is a retardation of the radionuclide, expressed through the retention factor. For a retention factor of 1, the radionuclide moves with the same velocity as the groundwater; for a retention factor of 1000 , the radionuclide noves 1000 times more slowly than the groundwater.

Many of the waste products can exist in different valency states in water. Different valency states have different retention factors. The redox potential of the groundwater determines the valency state of the dissolved waste product. To illustrate this effect, KBS quotes a Russian study (see Fig. 24). It shows groundwater percolating through a sandstone layer. close to the surface, the groundwater carries uraniun in its oxidized state (hexavalent uranium) in the form of a highly soluble carbonate complex with very poor retention. In zone II, containing larger amounts of organic carbon, uranium is reduced to 1 ts tetravalent state, which strongly sorbs in this layer. Beyond zone II, the groundwater, stlll having a reducing (negative) redox potential (Eh), Is quite depleted of uranlum. Many uraniun ores have been formed in this way.

Deep rock groundwater in Sweden is commonly reducing (Table 6). This recently discovered condition was not included in the KBS-I report, but was cosidered in the later kBS-II report. Table 8 gives retention values, based 


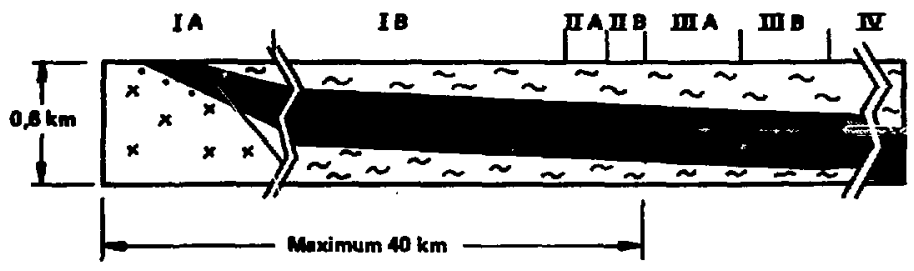

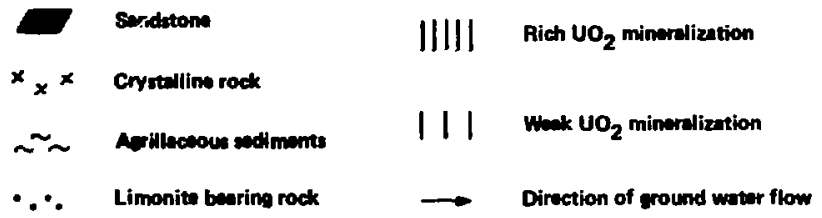

FIG. 24. Schematic illustration of the geological situation and the different zones around a uranium ore exposed to groundwater.

\begin{tabular}{|c|c|c|c|}
\hline Element & $\begin{array}{l}\text { Retention } \\
\text { factor }\end{array}$ & Element & $\begin{array}{c}\text { Retention } \\
\text { factor }\end{array}$ \\
\hline Strontium, Sr & 1500 & Radium, Ra & 48000 \\
\hline Technetium, Tc & 950 & Oranifur, 0 & 23000 \\
\hline Iodine, I & 1 & Neptunium, Np & 23000 \\
\hline Cesium, Cs & 4000 & Plutonium, Pu & 5700 \\
\hline Europium, Eu & 200000 & Americium, Am & 610000 \\
\hline
\end{tabular}

on laboratory measurements, for reducing groundwater. As is seen, only lodine moves with the groundwater velocity. Had the groundrater not been reducing, the retention factor of technetium (TC) would also have been 1 , and the factors for uranium and neptuntum would have been much smaller.

The importance of the retention factor may be illustrated by an exanple: If the water tranmport time is 500 years (from waste depository to water reservoir used by man), it will take plutonium $500 \times 5700$ years $=2.8$ allion years to reach man, However, since the half-ilfe of the longest lived 
plutonium 1eatope is 24000 years, 2.8 million years correspond to about 100 plutonium half-lives, Therefore, while plutonium slowly noves through the ground, it will decay radloactively, and in practice no plutonium will ever reach the water reservoir. The retention factors in Table $B$ are used for the final calculation of the amounts of radionuclides reaching man.

Retention factors have also been calculated for the clay barrier. It turns out that the two most hazardous fission products, cesium and strontium, are so strongly held by the clay that they decay completely before they can penetrate the barrler.

For similar minerals and grounowaters, the retention factors observed by the RBS Investigators are fairly close to those which other investigators have found in situ and through laboratory experiments.

\subsubsection{Dose Calculationg}

From the amount of groundwater seeping through the depository one can calculate the amount of radionuclides digsolved at a certain time under equilibrium conditions. Knowing groundwater movement and retention factors, the amount of radionuclides reaching a water reservoir can be estinated. The various reservolic of the ecosystem are described by Fig. 25 . For each reservoir, radionuclide uptakes by plants and animals have been calculated, using known radioecological "transfer factors." Finally, the radionuclide intake by man from food and water has been estimated. Three main cases have been studied: (1) The radioactive water flows into a valley in which there is a well near a lake (the "critical group" lives here). (2) The radioactive water flow is distributed equally between a nearby lake and a lake system downstream. (3) The radloactive water flows into the Baltic Sea. Rnowing the radionuclide intake, the dose recelved by exposed persons can be calcula .»d from known "dose factors."

The calculation scheme is sumarized in Fig. 26. Three different computer programs have been used. KBS claims that their "main case" 1 s very conservative, 1.e., the values chosen are all on the higher-risk side compared to the most probable values. Scne essentlal parameters for the main case and most pessimistlc case for the spent fuel alternatives are given below: 


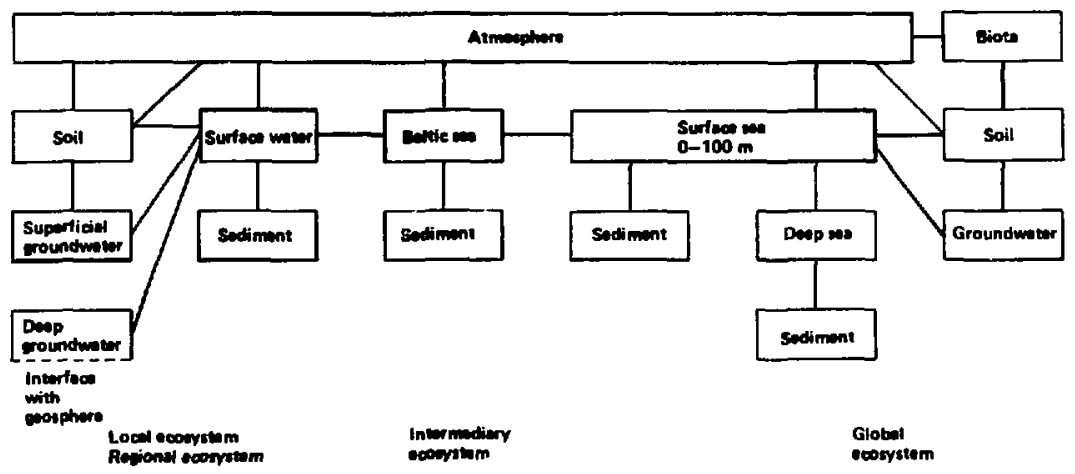

FIG. 25a. Reservolrs for the various ecosystems.

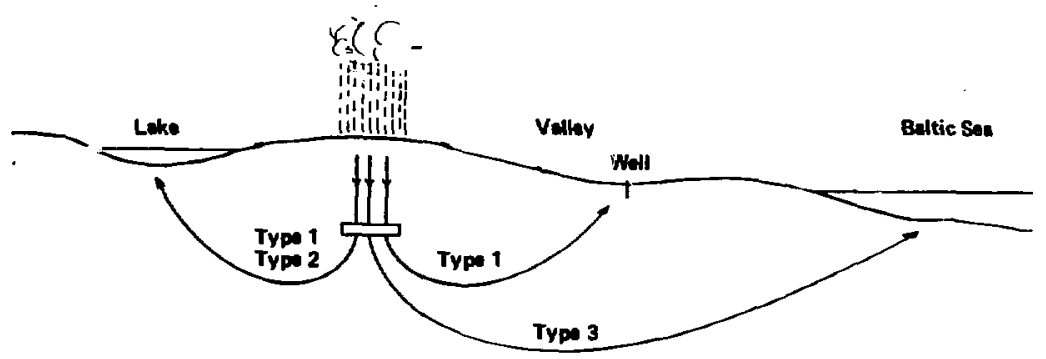

FIG. 25b. The three main paths of transport of radioactive substances to the blosphere.

\begin{tabular}{lccc} 
Case & $\begin{array}{c}\text { Canister penetration } \\
\text { time }\end{array}$ & $\begin{array}{c}\text { Water transit } \\
\text { time }\end{array}$ & $\begin{array}{c}\text { Retention } \\
\text { type }\end{array}$ \\
\hline Main & 100000 years & 3000 years & Reducing \\
Pessimistic & 100000 years & 400 years & Oxidizing
\end{tabular}

Some reviewers of the KBS profect have critlalzed the canister penetration lor dissolution) tine, which largely relies on the low oxidizing porer of the groundwater. 


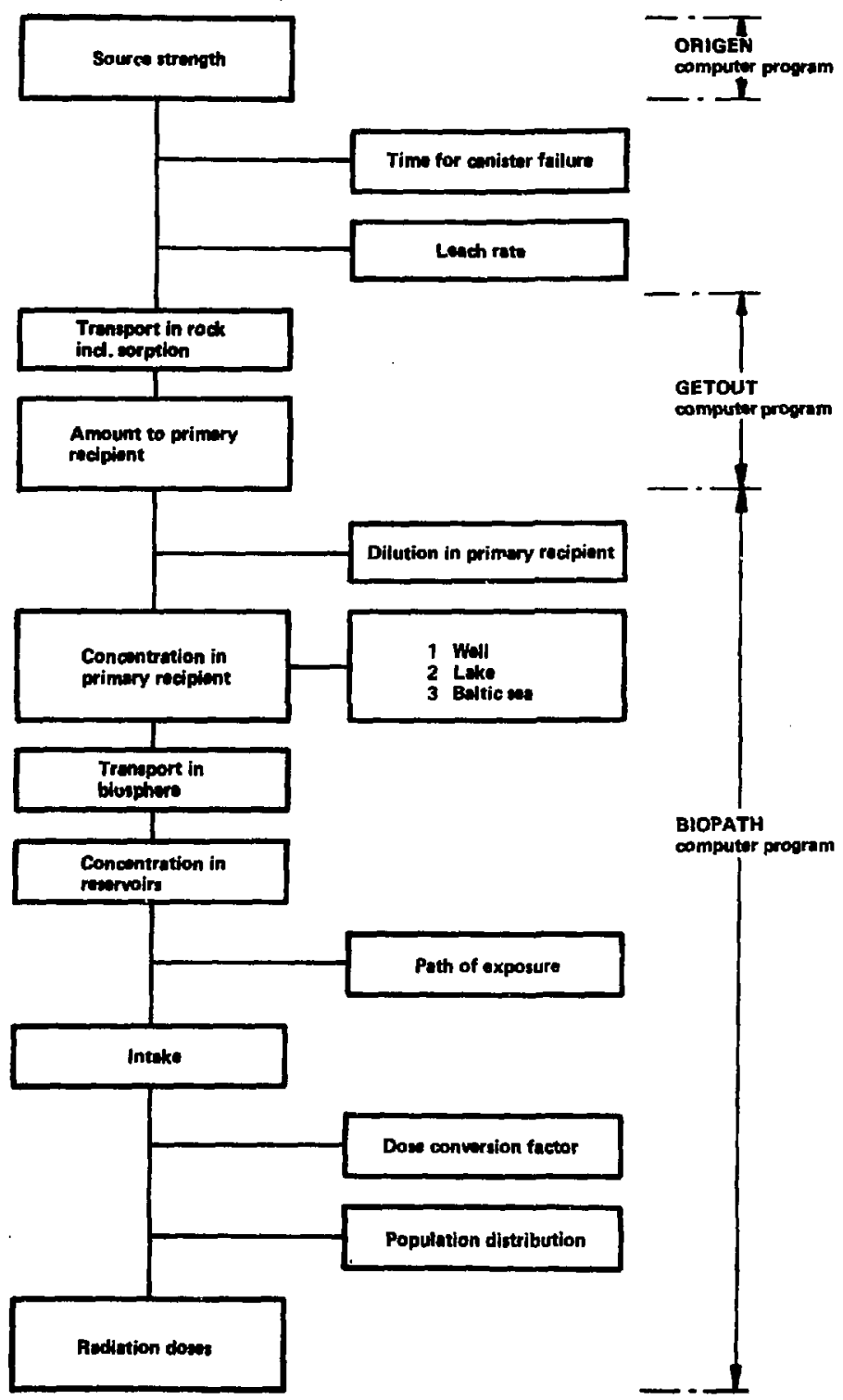

FIG. 26. Behene of calculation of radiation doses from the radioactive elements which wight be released Erom a final repository for spent fuel. 
The doses recelved by critical groups are presented in Fig. 27a for the main and the pessimistic case. The first peak, arriving after about 100000 years, is due to long-lived ${ }^{129} \mathrm{I}$ (half-life $1.6 \times 10^{7} \mathrm{yr}$ ), the second peak is due to long-lived ${ }^{135} \mathrm{Cs}$ (half-life $3 \times 10^{6} \mathrm{yr}$ ), and the third peak at 100 million years is due to uranium and daughter products. Figure $27 \mathrm{~b}$ shows the radionuclide sources of the calculated doses recelved according to Fig. 27 .

similar calculations have been made for the dissolution, transport, and uptake by man of radionuclides released from a storage of vitrified highactive waste from reprocessing. Figure 28 gives such a calculation based on the following data: the canister is penetrated after 1000 years, glass dissolves in 30000 years, water transit time is 400 years in rock, but including clay buffer it is 1500 years, and retention factors for oxidizing groundwater conditions. Flgure 28a glves the maximum Individual doses for this case and Fig. $28 b$ shows the radionuclide sources of the doses shown in Fig. 28 a.

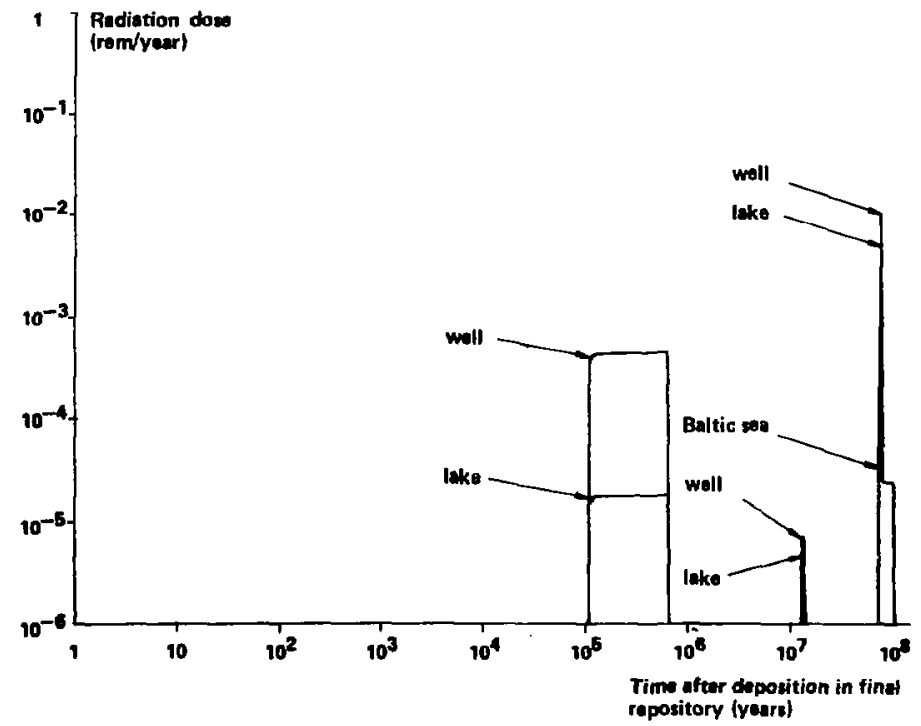

FIG. 27a. Calculated individual doses to critical groups (nearby residenta) for different prinary recipients. Hain case. 


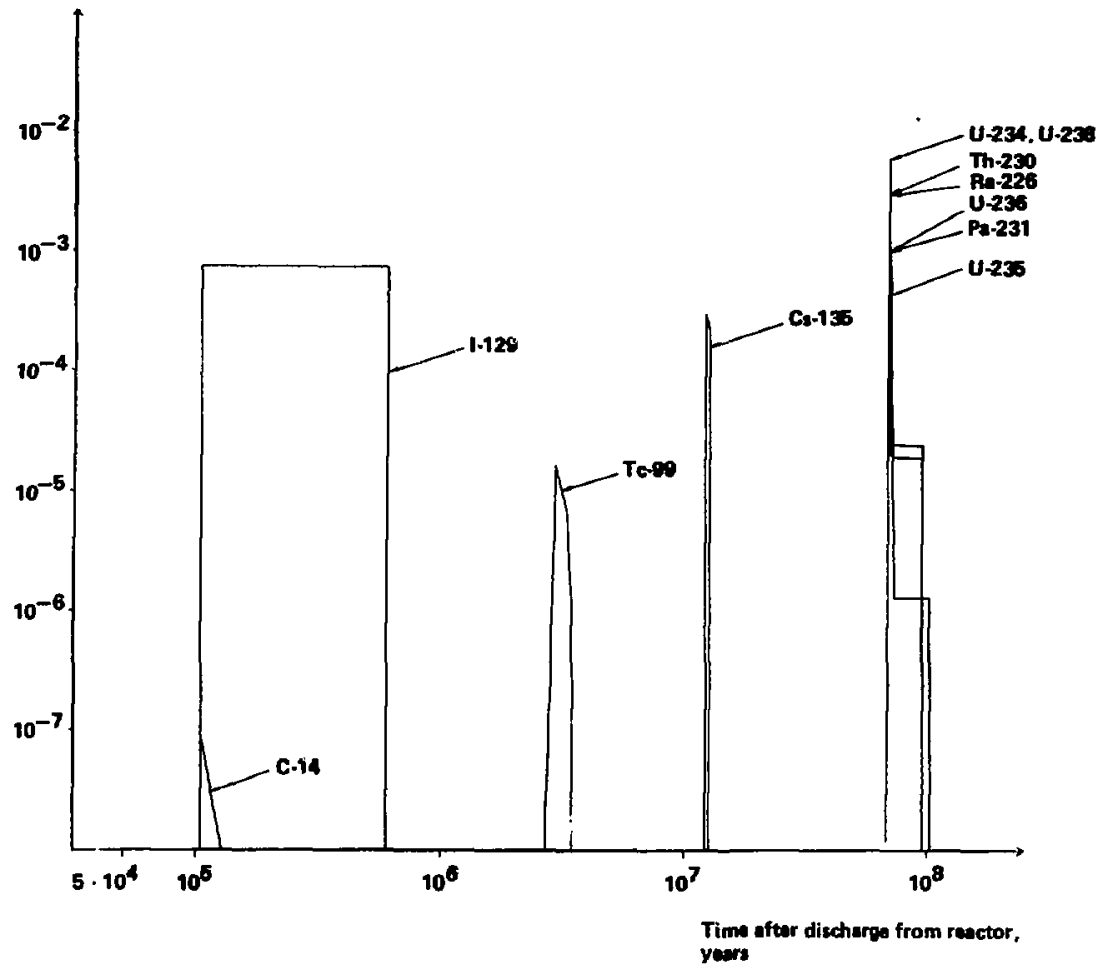

FIG. 27b. Results of GETOUT calculations. Inflow of radioactive elements to the recipient aice in the main case.

Figures 29 and 30 sumarize the doses expected to be received in the inain and the most pessimistic case from released waste radioactivitles for storage of spent fuel elenents and of vitrified reprocessing waste. In all cases the doses are below that of natural radiation and the ICRP recommended linits.

\subsection{REVIEWS OF THE KBS PROJECT}

Both RBS projects have been reviewed by experts. KBS-I was reviewed by meny national and international bodies, and kBs-II by 22 national and 12 


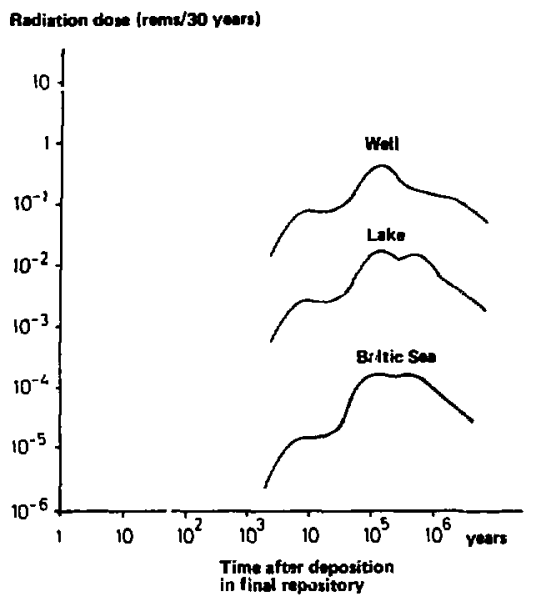

FIG. 28a. Maximum calculated individual doses to critical group (nearby residents) for different primary recipients. The calculations assume a glass leaching period of $10000 \mathrm{yr}$.

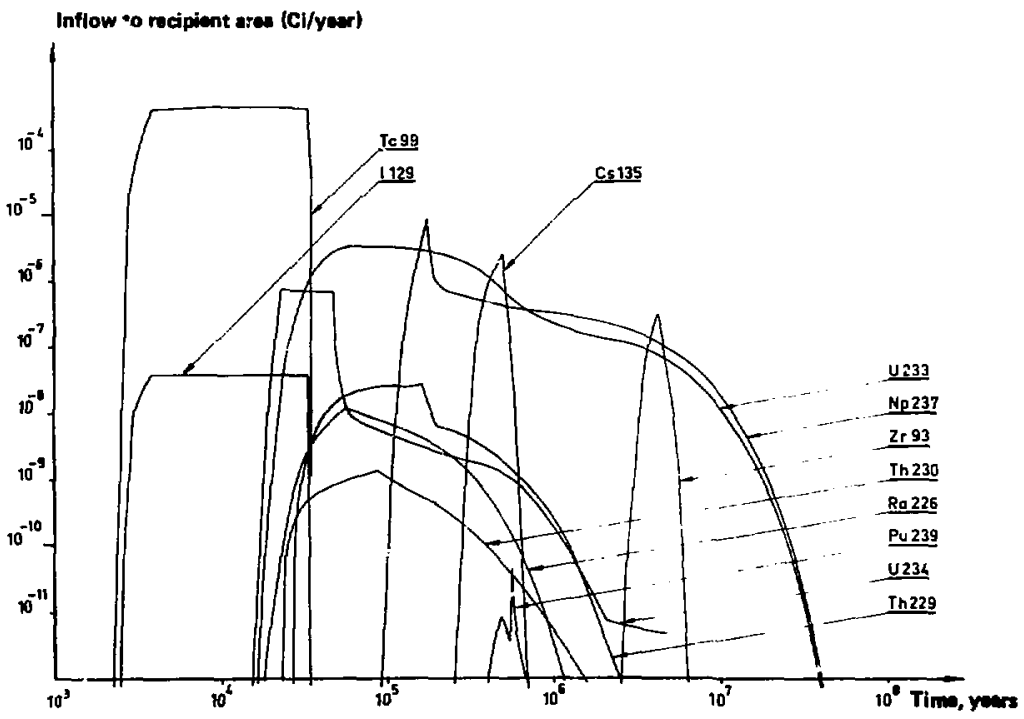

FIG. 28b. Brample of calculation of inflow to recipient area at various points in time, carried out using GEIOUr computer program. The dissolution time for the glass is $30000 \mathrm{yr}$. 
Hichest radision doses

from final repository

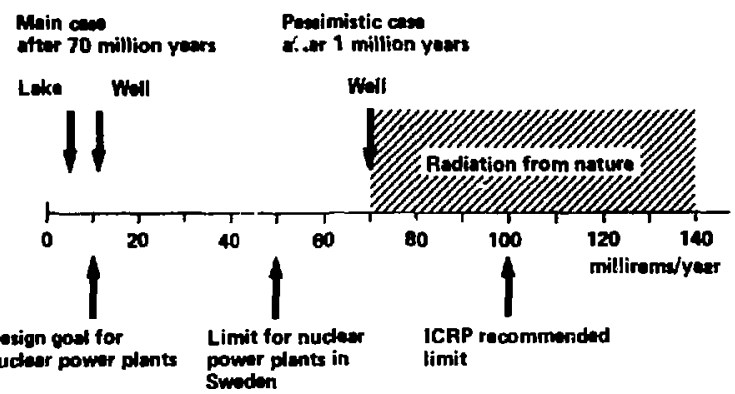

FIG. 29. The calculated maximum radiation doses from the final storage of spent fuel to an Individual compared with some limit ralues. ICRLP Is the International Commisation on Radiological Protection. Radiation from nature varies from one place to another in sweden and lies within the hatched area.

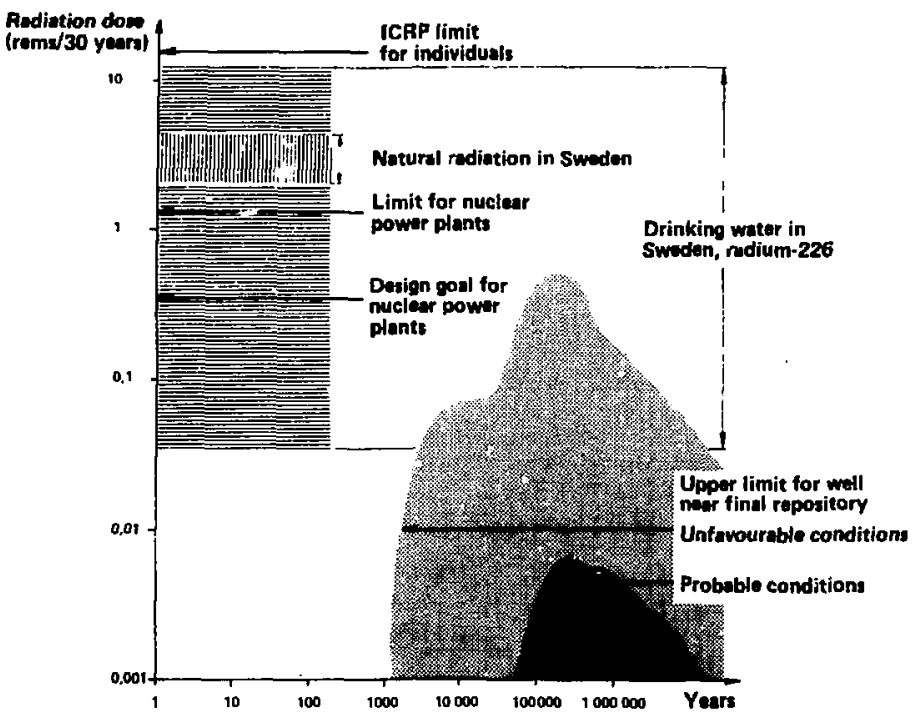

FIG. 30. Calculated upper linit for radiation doses to people who live near the final repository (critical group). The calculations pertain to the slow decomposition of the canister with a well as the primary reciplent. For purpoies of comparleon, the dose load from several natural radiation sources as wil a number of established dose linits have also been plotted in the diagran. 
International bodies, comprising scientific academies and institutions, Individual experts, and pub?ic-opinion groups. The international reviews of KBS-I have been published in a Swedish Government report (DiI 1978: 99), while the reviews of RBS-II (and pown industry coments) presently are collected in an unpublished report. The KRS has been allowed to respond to the reviewer's viewpoints. The Government's decision is made on the reviews and rebuttals obtained.

Same of the criticlsms of the RBS projects have been touched upon above. A survey of the critical viewpolnts will be presented below, but presentation of all reviewer's viewpoints and KBS rebuttals would require too much space.

\subsubsection{RBS-I (Disposal of Reprocessing Waste)}

For an 1nitial, early evaluation of the kBS-I project, the Swedish Government requested Professors J. Rydberg (Chalmers Technical University, Gothenburg, Sweden) and J. Winchester (Florida State Oniversity, Tallahassee) to reach an agreement on scientific certainties and uncertainties of the KBS proposal. In their over-200-page report (DsI 1978:17) these evaluators comend the general multibarrier concept and storage in granite rock, but raise questions about a number of 1ssues, such as (1) the proper interpretation of the stipulation Law, (2) the long intermediate storage time before final disposal, (3) the avallability of a sufficiently large rock body with sufficlently low permeability, (4) the effect of high temperature on corrosion of metal barriers and on the effect of clay, and (5) the rellability of the water ages presented. They also questioned the wisdom of basing a safety analysis on a series of "pessimistic assumptions" rather than the most probable case (with statistical spread to "optimistic" and "pessimistic" cases). In their overall conclusions Rydberg and winchester could not agree: Rydberg concluded that the RBS concept as a whole guaranteed that no more radiaactivity would leach out to nearby wells of drinking water than these wells presently contain because of natural radioactivity of the granite, while winchester concluded that the number of uncertainties showed that the concept did not fulfill the Stipulation Law.

Most reviewers have accepted the KBS statements on glass and canister stability (or aissolution times), though several pointed to the lack of extensive knowledge about the dissolution processes. In general, the oafety analysis schewe (Fig. 26) was also accepted. Criticism focused on questions 
of geologic stabllity and the avallabllity of a sufficlently large rock body with $10 \mathrm{w}$ groundwater permeability $\left(\leq 10^{-9} \mathrm{~m} / 8\right)$. Also, gone geologists were not satisfled that groundwater flow would be unaffected by future 1ce ages. Several reviewers contended that the RBS concept was not "absolutely safe," because of 2 imited knowledge of geochemical reactions between depository components (can1sters, backf1ll, and rock), especlally retention factors. The Iong time scale bothered some reviewers, considering the instability of present society and possibilities for sabotage. Many of the nonchemist reviewers (physiclets, geologlsts, etc.) refused to conslder retention as contributing to the safety of the depository.

\subsubsection{RBS-II (D1sposal of Unreprocessed Spent Fuel Elements)}

The International reviewers include National Acadery of Sciences, Environmental Protection Agency, United States Geological Survey, and Lawrence Livermore National Laboratory in the United states and CEA (France), IAEA (Vlenna), NEA (Brussels), and NRPB (UR).

The National Academy of Sclences states:

moth experiment and theory have demonstrated that the canisters will have sufficient mechantcal strength and corrosion resistance to survive in the designed repository enviroment for hundreds of thousands and probably more than a million years ..."

"Extensive research on bentonite clay has shown fairly convincingly that this materlal can protect the canlsters against mechanlcal alsturbance and corrosive attack by groundwater ..."

"The existence of at least one site In Swedish bedrock that meets the minimum criterla of dimension and 20 groundwater movement, though not conclusively demonstrated, is reasonably assured, and it can be inferred from avaliable geologic data that other equally good or better sites exist in Sweden ...."

"Desplte doubts by a very few Swedish geologists, there is substantial ewidence that over large parts of sweden the bedrock is tectonically atable so that a well chosen repository site is in little danger of damage from elther slow rock movement or rapid dislocations accompanying earthquakes. Observations of the effects of past glaclation in Scandineria indicate that possible renewed glaciation will cause no damage to a vell-constructed repository or damage too slight to pose a threat to the post-glacial biosphere ..." 
-Temperatures w11l be low enough so that their effect on corrosion of the canlsters and on the properties of the bentonite will be negligible. The rise in temperature in the rock around a repository $1 \mathrm{~s}$ expected to be below the level that might cause damage either by setting up convection cells in groundwater or by changing the fracture hydrology of the rock ...."

"It has been demonstrated fairly convincingly that the planned bentonite seals and backfill for shafts, tunnels, and boreholes after a repository is f1lled w11 be adequate to prevent channeling of groundrater. Nevertheless, the Subcomittee thinks that this 18 the weakest part of the KBS-II Plan ...*

"If unexpectedly rapld corrosion or a flaw in a canister should permit grounowater to come in contact with spent fuel rods, escape of dissolved nuclides will be greatly retarded by the insolubility of the urantun oxide pellets and by sorption and Ion exchange on bentonite and on mineral surfaces in the rock through which the groundwater moves. The retardation, plus effects of dilution and dispersion, is expected to ensure that concentrations In moving groundwater will not reach unacciptable levels ..."

"The Subcomnittee agrees that the available technical data are adequate to support the conclusion in the KhS-II Plan that radionuclides w11l not escape at unacceptable rates from a repository built as spec:iled in the RBS-II report, provlded thet constsuction is well englneered and a proper site is used."

The United States Geological Survey is concerned (as in their review of KBS-I) about groundwater flow, composition, and chemical reactions as well as effects of thermal stress on the rock. Although they agree that the proposal is sufficient to fulfill the stipulation Iaw, they fear that the economic value of copper, lead, and uranium in the repository makes future human intrusion probable.

The United States Environmental protection Agency contends that "solubility considerations drastically limit the amount of the nuclides that can be transported to people" and crealt the geohydrochemical description of the report. The Agency fears future disturiances of the repository because of its metal values and suggests a more thorough study of the consequences of such an intruaton.

The Energy Technology Center (at Chalmera Technical oniversity, Sweden; concludes that storage of spent fuel elements is inherently inferior to the utorage of reprocessing waste, considering handling technique and risks, economy, space, plutonlum control, resource preservation, enviromental burden 
on soclety, and long-range risks. The Energy Technology Center is critical of KBS safety analysib, especially of calculations of nuclide transport in the blogphere and the resulting doses to man, and it points out a number of technical deficiencies of the RBS-II report. Still, the Center finds the concept as a whole sufficiently trugtworthy for a realization.

The Lawrence Livermore National Iaboratory makes a technically detailed review, which 18 to extensive to sumarize here. They conclude that in a socially unstable world it would be better to diapose of the spent fuel elements as fast as possible. Though the radioactive risk after 1000 years is comparable to other natural risks, the dissolution of the canister may lead to lead polsoning, which is a larger risk. They recomend using an alunina canister and reprocessing to reduce the above risks. In sumary, they conclude that the RBS concept is "exceedingly aafe."

In accordance with Swedish rules, KBS has been given the opportunity to respond to criticism from the reviewers. Discussions have been conducted with KBS and consultants, and the final RBS reply is now ready. RBS is now considering whether to publish its final conclusion-which will lead to additional public debate--or to wait until early in 1983 . That will be the latest possible time, because in May 1983 SKBF (parent organization of rBS) has to request permission from the government to load the reactors Forsmark III and Oskarshamn III. Such loading will be granted only when the nuclear Industry has proven that spent reactor fuel can be safely stored (KBS-II concept). RBS reasons that 1t can be advantageous to waft until early 1983 for more confirming results for their RBS-II proposal.

\subsection{RECENT CAANGES}

A new law was introduced in sweden on July 1, 1981. According to this law (see Appendix $\mathrm{E}$ for full text) the nuclear power prcducer is responsible for all nuclear fuel back-end management. This law makes the power industry responsible for designing and operating all handling equipment, treatment, and storage facilitles for gpent fuel elements and all kinds of radiouctive waste (low, medium, and htgh) for all time. Fart of this responsibility can be met on a contracting basis, as in the example of reprocessing, for which SRBF (the jolnt organization of the nuclear power industry) has a contract with cogera in France. The governient has created three organizations to oversee this activity: 
1. Stitens stralskyddsinstitut (SSI). The Mational Radiation Protection Institute is responsible for radiation levels and can stop all operations which exceed permitted levels. The present head is Profagaor B. Iindell.

2. Statens kirnkraftsingpoktion (SkI). The National Nuclear power Inspectorate sets standards for reliable and gafe operation of all nuclear facilities and can order the shutdown of any facility not meeting these standards. The present head is Professor I. Nordstrom.

3. Nämnden för hantering av anvïnt bränsle (NM̈BnB). * The "state Bourd for Spent Fuel Management" was created on July 1 , 1981. It has to perfodically review the nuclear power Industry activities in dealing with waste, as further described below. The present chaiman is S. Romanus, and the director is Gerhard Rundquist.

Organizationally, SSI is part of the Department of Agriculture, and SKI and MAHAB are parts of the Department of Induatry.

According to the new law, the power companies have to set aside funds for future expenses for waste management. At present, 1 öre/kmh is set aside (electricity now costs about $12 \mathrm{bre} / \mathrm{kwh}$ ). The funds are controlled by vïHa, but used for all steps of the backend, such as:

(1) Construction of transport vessels and ships; to be delivered in 1982.

(11) Construction of central spent fuel storage facility (CIAB): will be ready in 1985 .

(111) Construction of storage for medium and low-level raactor waste (SFR) , construction permit will be requested in February 1982, builaing complete in 1988.

(iv) Construction of Intermediate storage for high level waste; buliding will be ready to accept Hringlass in 1990.

(v) Test drillings and design of final storage for apent fuel elements and tur-glass.

\footnotetext{
*Preliminary abbreviation.
} 
(vi) Remenrch and design for all above activities $\$ 10$ million will be net aside annually for problen related to the safoty of the final wate storage (glass discolution, geochemietry, radionuclide algration, etc.), probably one third of this will be epent on chenical problems.

On all these queationa IBS will let the contracts and draw money from the fund. Control by viting will probably be exercised only after a project has been running for som years. 


\section{PRESEAT RESEARCH EFTOKIS}

The Swedish research efforts descrlbed below concern mainly high-level waste, though work on medium- and low-level waste is also studied by the research organizations mentioned. (See also Fig. 31.) Nost of the effortg have bee atimulated by passage of the stipulation Law, though PRAV conducted some waste activities even before them. In addition to the applied research described below, the National science Research Council supports sone basic research of importance to the waste studieg-for example, studies of actinide complexes in aqueous media.

\subsection{RRS RESPARCH AND DEVELOPAENT EFFORTS}

There has been a close collaboration between the research and development efforts of the present KBS profect, with an annual budget of 20-25 Mkr (\$5-6 million), and the PRAV projects (Section 3.4), with an annual budget of about $15 \mathrm{Mkr}$ (about $\$ 3.5$ milition). Originally, PRAV was to support more long-range and semi-basic projecta and RBs was to meet the more immediate demands of the nuclear industry. However, the activities have been overlapping in this respect, though not dupllcating. The good collaboration between PRAV, KBS, and SKBF has been facilitated by their adjacent adinistrative organizations in the same building. From July 1, 1981, PRAV is replaced by NïHAB (see Section 2.9). Some of the IBS efforts are sumarized below.

The coments of the reviewers on the RBS-I and RBS-II reports have made it clear that, in general, they considered the isolating properties of the geologic barrier not to be as well verified as the containment function of the engineered barriers. Accordingly, the major emphasis in the ongoing research and development program is on further studies of the properties of the geologic barrier.

\subsubsection{Identification and Selection of Rock Bodies for Waste Disposal}

It is conaldered necessary, mainly for political reasons, to make a complete aurvey of the country for rock bodies suitable as depositories. This survey proceedi in steps. It starts with a general survey of (1) portions of the country with the aid of air photos, phyalographic and geologic maps and 


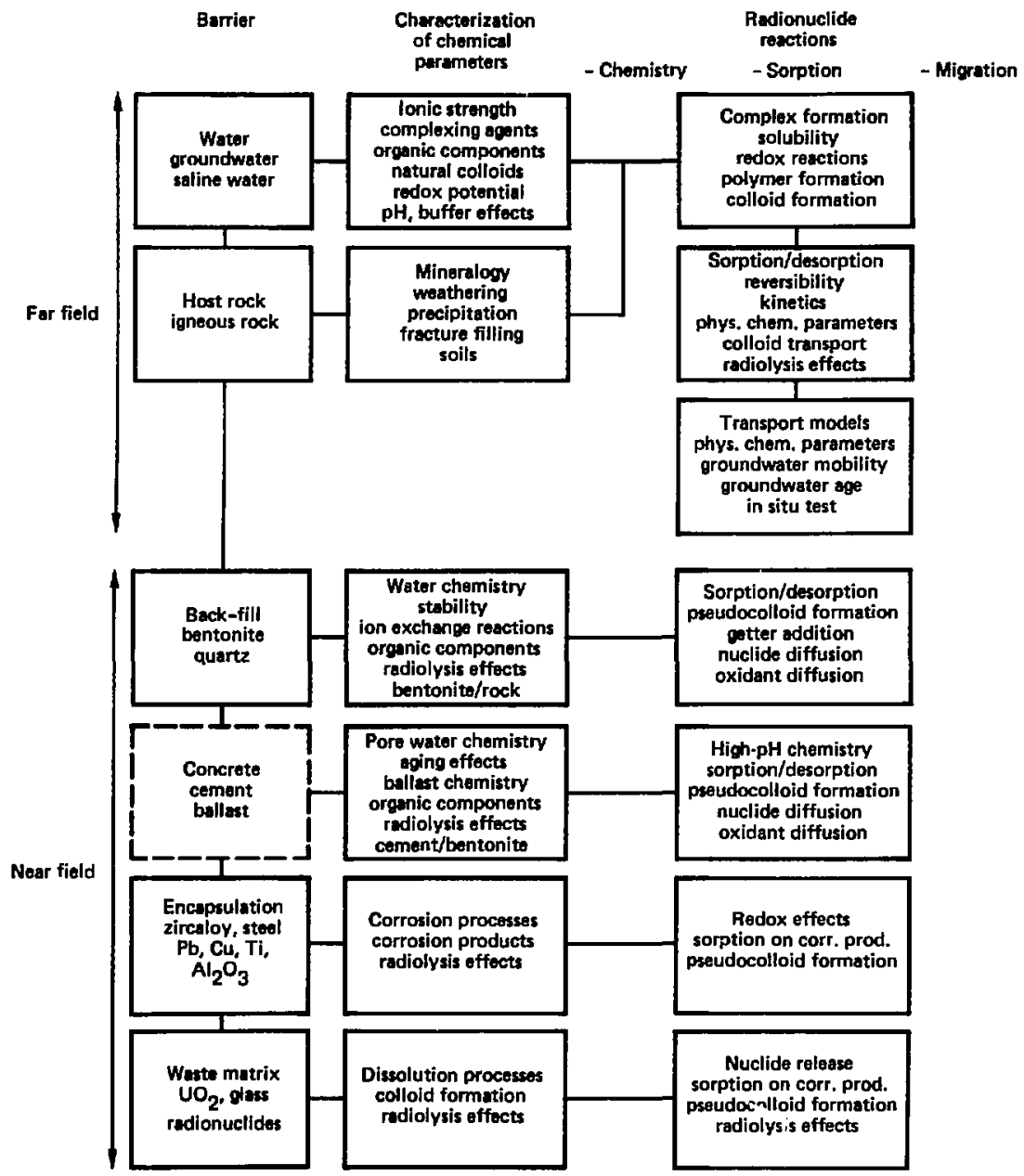

FIG. 31. Swedish flelds of research on nuclear waste safety. 
(2) we archives on well drillings and rock work at the Geologic Burvey of sweden. It continues with (3) ground reconnalssance of the promising areas. The two or three areas that are best oulted for geologic Investigation and are Judged to have the desired quality are (4) selected for geophysical measurements, drillings, and borehole loggings. This program will over a five-year period give data from 10 to 12 sites which should be representative of all types of suitable bedrock in sweden.

A Becond five-year period will be used for further studles at a few of the sites that represent different rock types. During this period kBs should be able to include investigations suggested by experience from the hydrological and geochemical work.

\subsubsection{Selsmigity and Neotectonice}

Programs for these studies are now being developed. There 18 reason to hope that the knowledge about the existence and precise extension of active fault zones will increase considerably during the next 10-year period. A few fault lines have been identifled where vertical displacements have taken place since the last glaciation. Studies of one or two of these are being planned.

\subsubsection{Eydrogeology}

The bedrock at Finnsjön was used as model site in the safety assessment of the KBs report. The hydrogeologic program at that site has been greatly expanded. Studies will be made of groundwater balances, infiltration, water table variations, groundwater runoff, hydraulic connections in the fracture system, groundwater age at various depths, and age differences along identified groundwater flow lines. Field applications of the geochemical research program could also be made here with advantage, as tracer flow tests (Br-, etc.). Improved well-logging instruments are also tested.

\subsubsection{Geocherietry}

This ambitious program, which has been carried out with support from PRHV, w1ll cover the apectrum, frcm research on chonical equilibria in representative groundwater types to in situ measurenento of radioactive nuclide algration in fractures in cryetalline rock. Some of the programs are 
- Chemical equilibria between releazed radionuclides and species in natural groundwater.

- Formation of radiocolloids.

- Interaction between rock minerals and groundwater.

- Sorption of noncolloid radionuclides on rock surfaces and on pure minerale (batch and column).

- Radiocolloid migration (column).

- Chemistry and transport propertiea of radionuclides in artificial barriers (clay, concrete, etc,).

- Transport models considering pore water effects.

- In situ radionuclide migration in fractures.

There are also ongoing investigations of fracture mineralizations in core samples and boreholes of various rock types. Since medium- and low-level waste may be stored close to the surface, underlying peat and clay minerals are studied for permeability, nuclide retention, etc.

\subsubsection{Stripa Experiments}

stripa is an abandoned Iron mine in central sweden. The Iron ore body was located in a larger granite formation, which now is crisscrossed with corridorg down to about $400 \mathrm{~m}$ below the surface. The stripa project, started by KBS in 1977 in collaboration with the us Department of Energy, intended to study the potential of granite rock formations to isolate radioactivity over very long periods of time, and to perform appropriate tests. In 1981 the "International stripa Project" was launched by the Nuclear Energy Agency (NEA) with seven contracting countries. The project is further described in Appendix $c$.

\section{1 .6 Safety Analyzia}

This includes updating of present prograns, improved modeling for water flow in rock fiasures, introducing retention data for $\mathrm{w}_{2}$, etc. Uptake of uranium and radon by plants io studied at studsvik and oltuna. 


\subsubsection{Glass Research}

Stability and leach rate of varfous host glasses for high-active waste are studied through the Glass Research Institute in collaboration with the Department of Energy and NAGRA (Switzerland). In situ glass leaching has started at Stripa.

\subsubsection{Bentonite}

The colloid properties of bentonite have been carefully studied. Full-scale injection tests of bentonite in rock fractures are going on. Bentonite properties (swelling, permeability, diffusion, pressure, etc.) at different temperatures are studied in situ at stripa. Project leader is Professor R. Pusch at the Luled Technical University.

\subsubsection{Naste Handling}

Handling of medium- and low-level waste containing $\alpha$-emitters is studied on the basis of the kBS concept. Fnclosure by hot lsostatic pressing Into $\mathrm{Al}_{2} \mathrm{O}_{3}$ is tested, the technique 18 being evaluated by Cogema. Also, ASzh is developing encapsulation in copper by hot loostatic pressing.

\section{1 .10 CINB}

SIBF 18 managing a construction project for an "away-fron-reactor" wet storage for spent fuel (CraB) with a design capacity of 9000 tonnes. Th1B project is now in the construction stage. It 1s located on the Oskarahamn power plant gite. The firat one third (1.e., 3000 tonnes) will be in operation in 1985.

\section{1 .11 SPR}

A facllity for final atorage of reactor waste (SFR, previously naned Nun) 1a being designed. It is planned to locate it at the Foreark power plant. $A$ construction permit will be requested In 1982 , the facility will be 
ready in 1988. It will consist of 4 large concrete silos, 50 m diep and $30 \mathrm{~m}$ in diametex, at $40 \mathrm{~m}$ depth in bedrock covered by 10 m of water (Baltic sea). Bltumen barrels, concrete blocks, etc. (about $100000 \mathrm{~m}^{3}$ ) will be atored in the silos, surrounded by a bentorite packing.

\subsubsection{Transportation}

Transport containers for spent fuel elements from bolling-water reactors and pressurized-water reactors have been designed in collaboration with Cogema, as well as a 2000-tonne transport ship, which is now being built in France.

\subsubsection{Time Schedule}

There has been no authorization in Sweden of a master time schedule for the development of a geologic disposal facilfty. The research and development program is therefore running on an ad-hoc time schedule based on the RBS proposal that no high-level waste should be disposed until around 2010. This leads to a very coarse overall diviston of the avallable time.

\subsection{THE STRIPA PROJECT}

In July 1977 the Swedish State Power Board and the U.S. Department of Energy, through their contractors, the Swedish Nuclear Fuel Supply Company (SKBF) and the Lawrence Berkeley Laboratory (LBL), began to study the feasibility of storing radioactive wastes in mined granite caverns, at Stripa, about $200 \mathrm{~km}$ northwest of stockholm. During the last three years a series of tests has been carried out addressing the problem of predicting the thermomechanical behavior of a heterogeneous and discontinuous granite mass and predicting the movement of groundwater through such granite.

The RBS work program includes the following:

- Studies of mining technlques conducted by ställbersbolagen, the mining company which owns and operates the stripa mine.

- Subsurface geologic mapping of fractures in the underground openings, by the Bredish Geologic Survey.

- befect of pressure and temperature gradients on rock permeability. Hagconsult is measuring water flow rates between vertical holes in the rock as a function of preasure and temperature. 
- Grouting studies.

- Thermal stress stuales.

- Hydrologic studies in a deep borehole (410-900 m).

- Determination of in situ stress (University of Lulea).

- Laboratory determination of rock properties.

The U.S.-Sweden cooperative program has covered the following tasks:

- Task 1. Full-Scale Heater Experiment, to Investigate the effects of temperature increases in crystalline rocks. Two heaters the size of waste canisters, with an output of up to $5 \mathrm{kw}$, have been operated for about two years.

- Task 2. Time-scaled Heater Experiment, to determine the Iong-term effect of waste heat in a fractured rock mass.

- Task 3. Assessment of Fracture Hydrology, to define the surface and subsurface hydrological conditions of the fractured granite rock mass as a function of time and temperature, using various borehole tests.

- Tark 4. Geophysical Assessment of Fractured Rock Masses, to determine the applicability of differert surface, subsurface, and borehole techniques to locate the fracture system in granite rock masses.

- Task 5. Laboratory Measurement of Material Properties, to measure the properties of rock samples from the stripa nine.

- Task 6. Mass Transfer of Waier to the Ventilation System, to determine the gross seepage rate in the low-permeability granite rock at stripa.

- Task 7. Measurement of in Situ Stresses by Hydraulic Fracturing, to determine the virgin stace of otress in the stripa rock mass.

Figure 32 sumurizes the hydrogeological theoretical approach of the stripa studies.

In the stripa mine iron ore has been produced since 1485. It was closed in 1976 by its latest owner, stälbergsbolagen. The mine drew its ore from hematite-rich zones in leptite, a quartzofeldspathic metamorphic rock of the granulite facies. This leptite was intruded by a medium-grained granite in which a conslderable part of the mine accessways are located. It is from such drifts at the $360-m$ level of the mine that drlfts were excavated for the in situ heater tests and other experiments at the $338 \mathrm{-m}$ level.

The essential result is that the heat load tested has relatively gall effect on the overall hydraulic conductivity, which $1 \mathrm{~s} 10^{-11} \mathrm{~m} / \mathrm{s}$ in large-scale tests. 


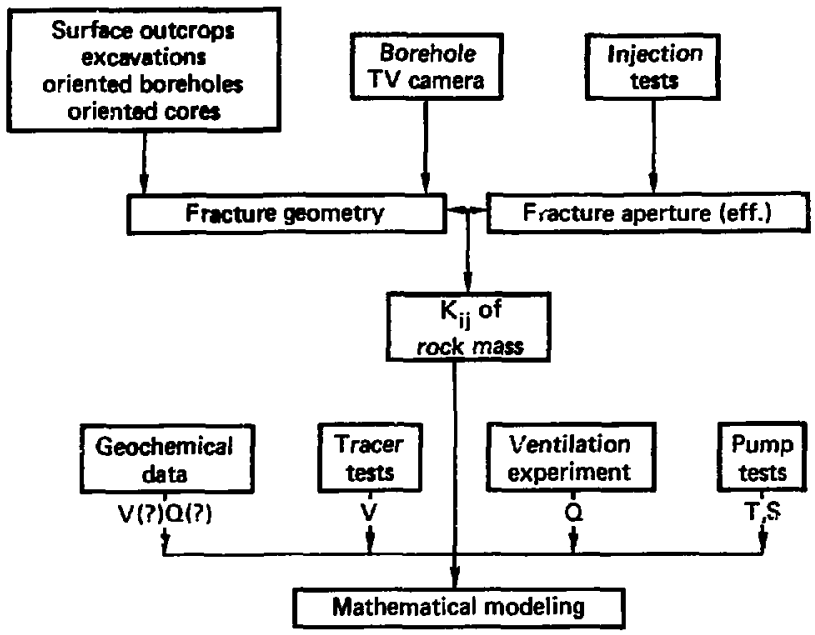

FIG. 32. Block diagran of steps in calculating directional permeabilities from fractire data.

Groundwater seems to be dipided into two regions, one originating from the aurface and pelietrating down to at least the 400-m level, and one region consisting of fossjl seawater and subglacial melting water below about $600 \mathrm{~m}$. This water seems to be very old, as is indicated in Fig. 33.

The findings at stripa are being published in a Berles of joint reports by SKBF And LBL. Appendix $C$ is a sumary of the hydrological findings up to March 1980.

In 1981 OECD/NEM entered into the "International strip project" with FInland, Japan, sweden, Switzerland, and the United States as full participanta, and Canada and France as assoclate members. The work progran of the project, already under way, concentretes on the following main areas:

- Hydrogeological and geochemical Investigations in boreholes excavated fram the mine "botton" at about $350 \mathrm{~m}$ below the eurface down to $1400 \mathrm{~m}$.

- Ion migration teste in single fissures to study radionuclide transport mechanims through the geolegic medium.

- Investigation of backfill material used to buffer the waste from the rock and to plug access and boreholes that offer potential pathways to the blosphere. 


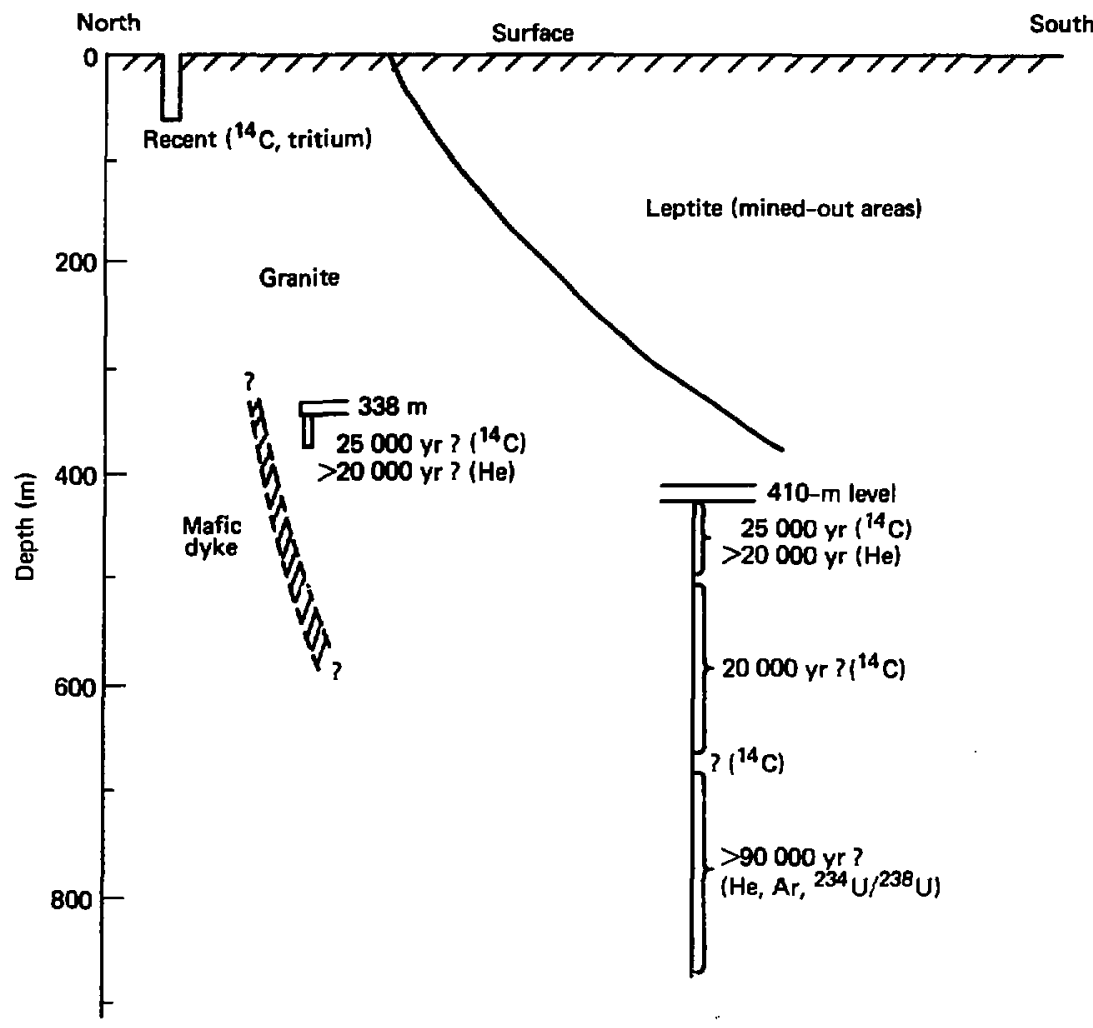

FIG. 33. Preliminary results of lsotope age dating of groundwater samples.

- Leaching of glass in true geologic environment.

This project will be continued until 1984 at a cost of about $\$ 10$ million.

\subsection{ASEA CERAMIC CANISTER}

The ASEA company is the largest electric supply company in sweden, AsEn-ntom, aubsidiary company, builds boiling-water reactors, and has no far delivered eight such stations. ASE also manufactures industrial diamonds, tool steel, and cemented carblde of extreme hardness. These producta are 
fabricated through the use of hot 1sostatic pressing, at temperatures up to about $2000^{\circ} \mathrm{C}$, and pressures up to several thousand bars (100 MPa). The pressure 18 applied evenly (1sostatic) through a gas system. pieces with dimensions up to several meters can be fabricated in this fashion.

Using this technique, ASEA has developed a container for spent reactor fuel elements at 1 ts laboratory at Robertsfors. The container is $\alpha-a l u m i n u m$ oxide $\left(\mathrm{Al}_{2} \mathrm{O}_{3}\right)$ of high purity, (99.88) sintered at $1400^{\circ} \mathrm{C}$ and $100-300 \mathrm{MPa}$. The process transforms the $\mathrm{Al}_{2} \mathrm{O}_{3}$ into corundum, the density of the sintered material is 99.58 of the theoretical. Corundum 1s, next to dianond, the hardest material in nature. $: s$ appears naturally as ruby, sapphire, and emery.

since the material is found in nature in geological formations which are a thousand million years old, it is obvious that the corundum has an extremely high resistance to natural destructive processes. Thus, in water of $80^{\circ} \mathrm{C}$ and $\mathrm{pH}$ 8.5--conditions expected in a radioactive waste repository--the dissolution rate is equivalent to less than $0.07 \mathrm{~mm}$ in 1000 years. Stated otherwise, a 10-cm (4-in.) thick corundum vessel will not dissolve completely in one million years. In fact, experiments inálcate that the granite rock will dissolve sooner than corundum canisters placed in the rock.

The process for canning spent fuel elements in full-scale corundum canisters has been tegted. Figure 34 shows a full-size canister. The spent fuel elements (two at a time) are placed in a stainless steel tube, air is removed an the tube is sealed, the tube is then rolled flat, coiled in a specially designed mill, and placed inside the preformed canister. When the canister is filled to one half its volume with rolled colls, the upper internal volume is filled with $\mathrm{Al}_{2} \mathrm{O}_{3}$ fibers and $\mathrm{MgO}$ as heat insulators, before the top is sintered onto the body of the canister. In this way a seamless seal is produced. The technigue for enclosing unrolled spent fuel elements is presently being developed.

Figure 35 shows the pre luction chain for the alumisum oxide canisters, and Fig. 36 11lustrates the encapsulation procedure for the spent fuel elements. This is also 1llustrated in Fig. 37. Figure 38 shows the closing of the container, followed by hot lsostatic pressing, which produces a completely seamless canister.

Table 9 sumarizes the characteristics of the container material. It can be seen that the dissolution rate is less by a factor of about 10 than the presently assuned rate for the disaolution of vitrified waste. Dissolution studies in true groundwater have, in effect, shown that no dissulution at all 


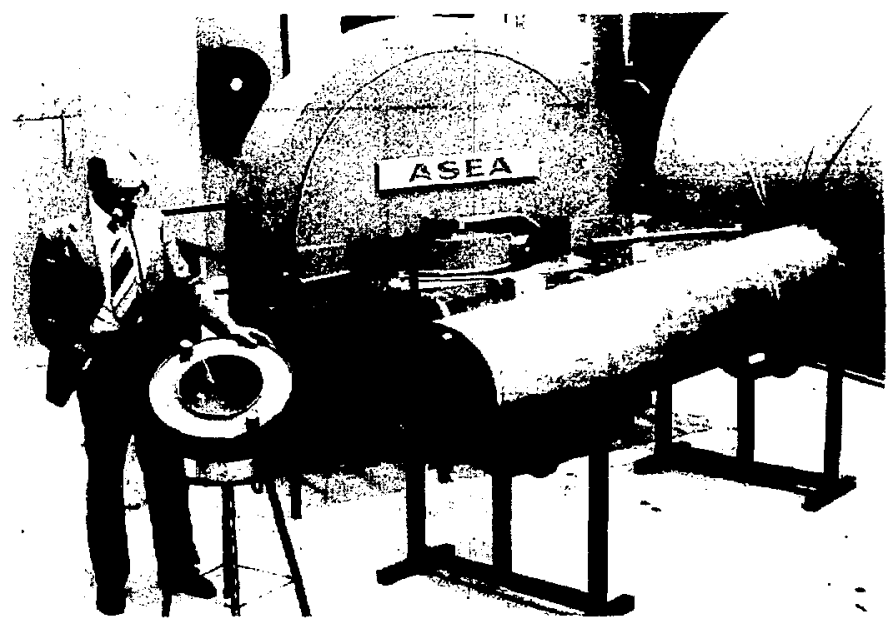

FIG. 34. Full-size canister of aluminum oxide for direct disposal of spent. nuclear fuel. In the background, the quINTUS press for hot-isostatic pressing.

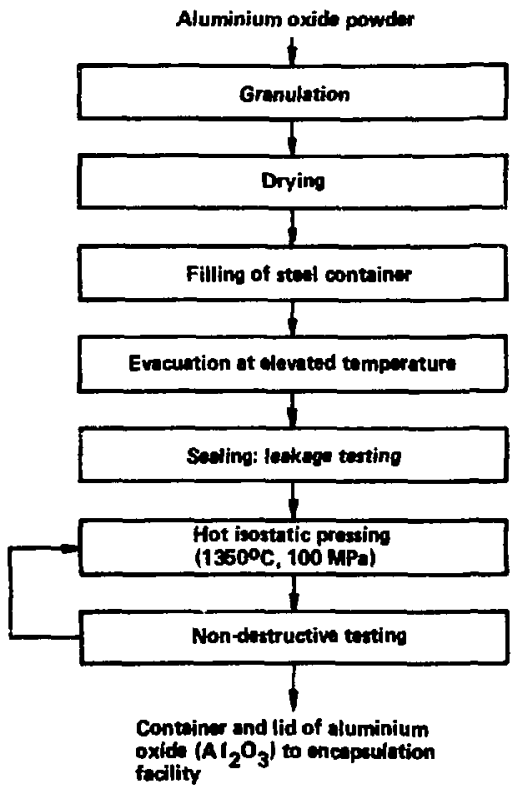

FIG. 35. Schematic diagran of production chain for aluninu oxide canister for epent nuclear fuel. 


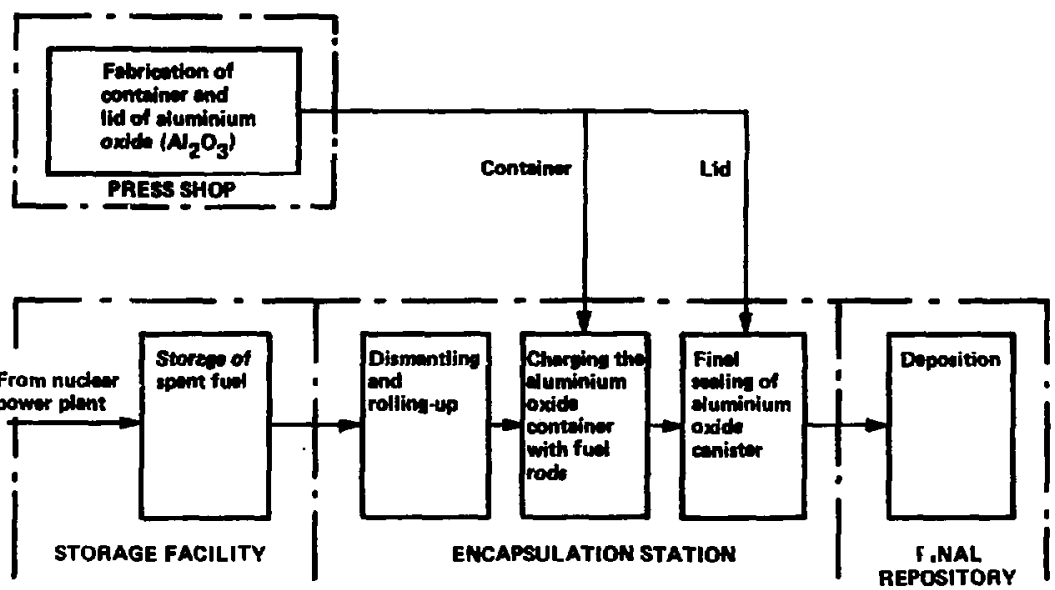

FIG. 36. Block diagram illustrating encapsulation of spent nuclear fuel in aluminum oxide canister.
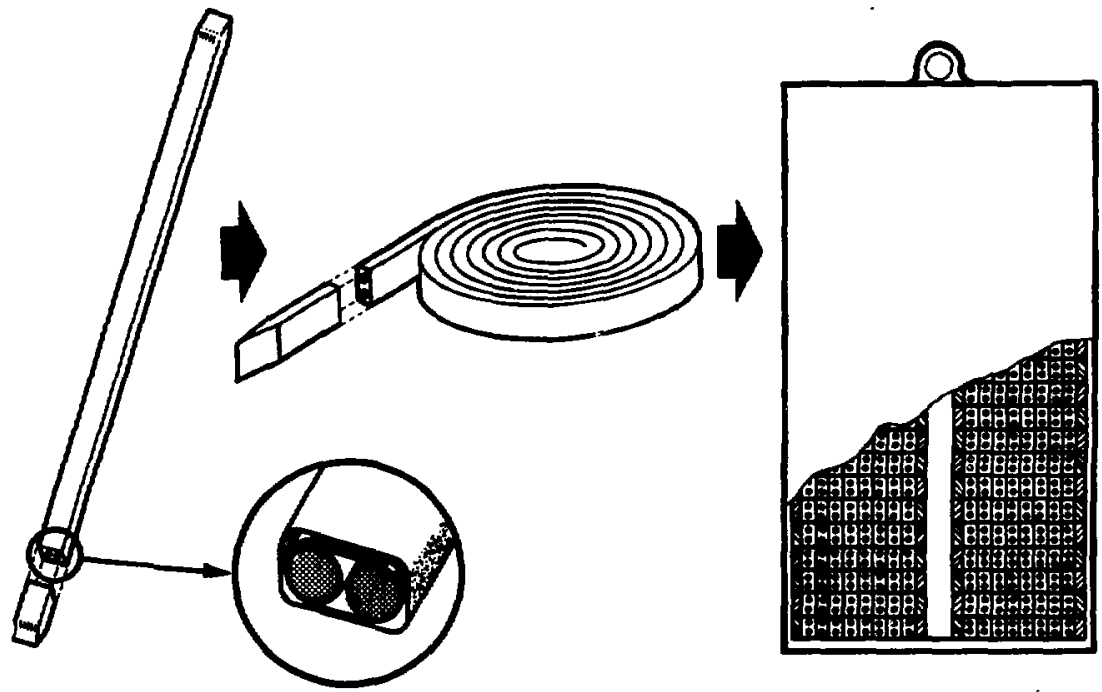

EIG. 37. The fuel roda are encapsulated in pairs in ateel sheaths which are then rolled up. The resultant colls are packed in a cylinder of stainless steel. 

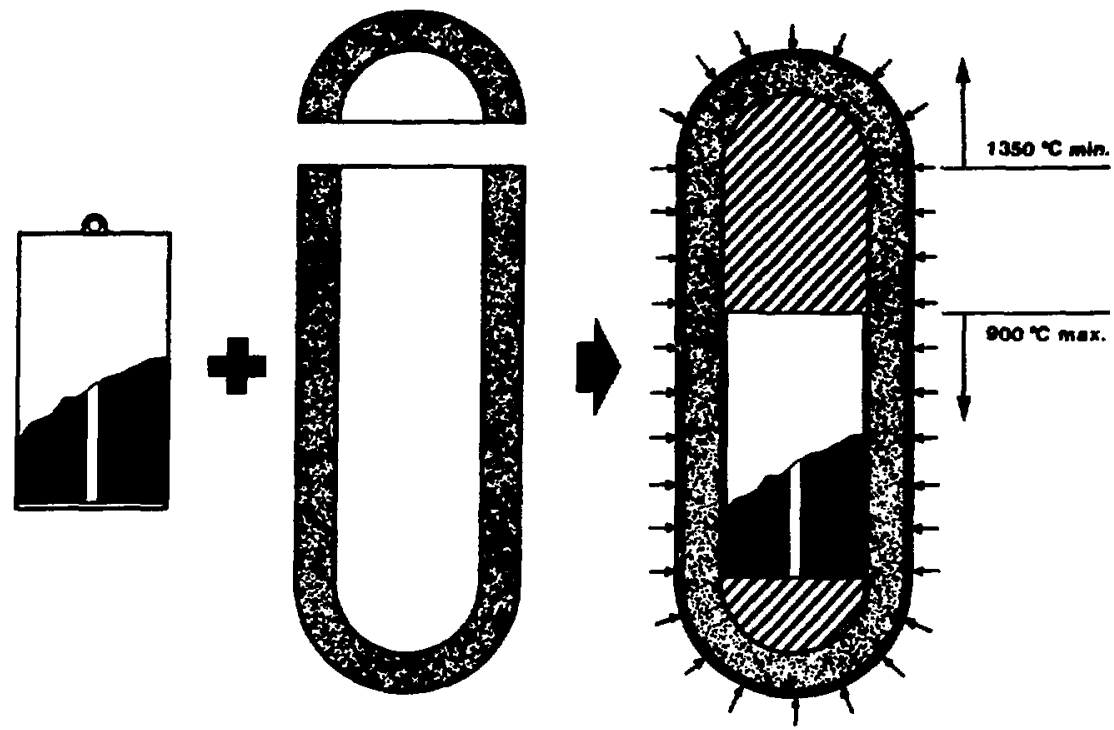

FIG. 38. The stainless steel oylinder with fuel rods is placed in the contalner. The lid and the container are sealed by means of hot isostatic pressing to produce a completely seamless canlster.

takes place. Inatead, silica and metal fons in the groundwater react with the alumine to form alumino-silicates of rock type, which leads to some Increase In the wall thickness.

Although the technique has been developed for unreprocessed spent fuel elements, there is no reason why it should not be applicable to high-level vitrified wate. It ghould also be noted that the canister is not irretrievable. It can be cut open with a dianond tool, a technigue which is well established.

Resources of bauxite and other aluminium-bearing raw materlals are virtually inexhaugtible. The cost of high-purity alpha-aluminium oxide powder is currently around Skr $5 / \mathrm{kg}$ (US $\$ 0.5 / 1 \mathrm{~b}$ ).

\subsection{MATIONA COACIL FOR RADIOACTIVE haSTE}

The council was formed late in 1975 in order to support the exploratory and developrental work necessary for the nuclear power program which the 
TABLE 9. Characteristic properties of $>99.8$-pure alpha-aluninium oxide $\left(\mathrm{Al}_{2} \mathrm{O}_{3}\right)$.

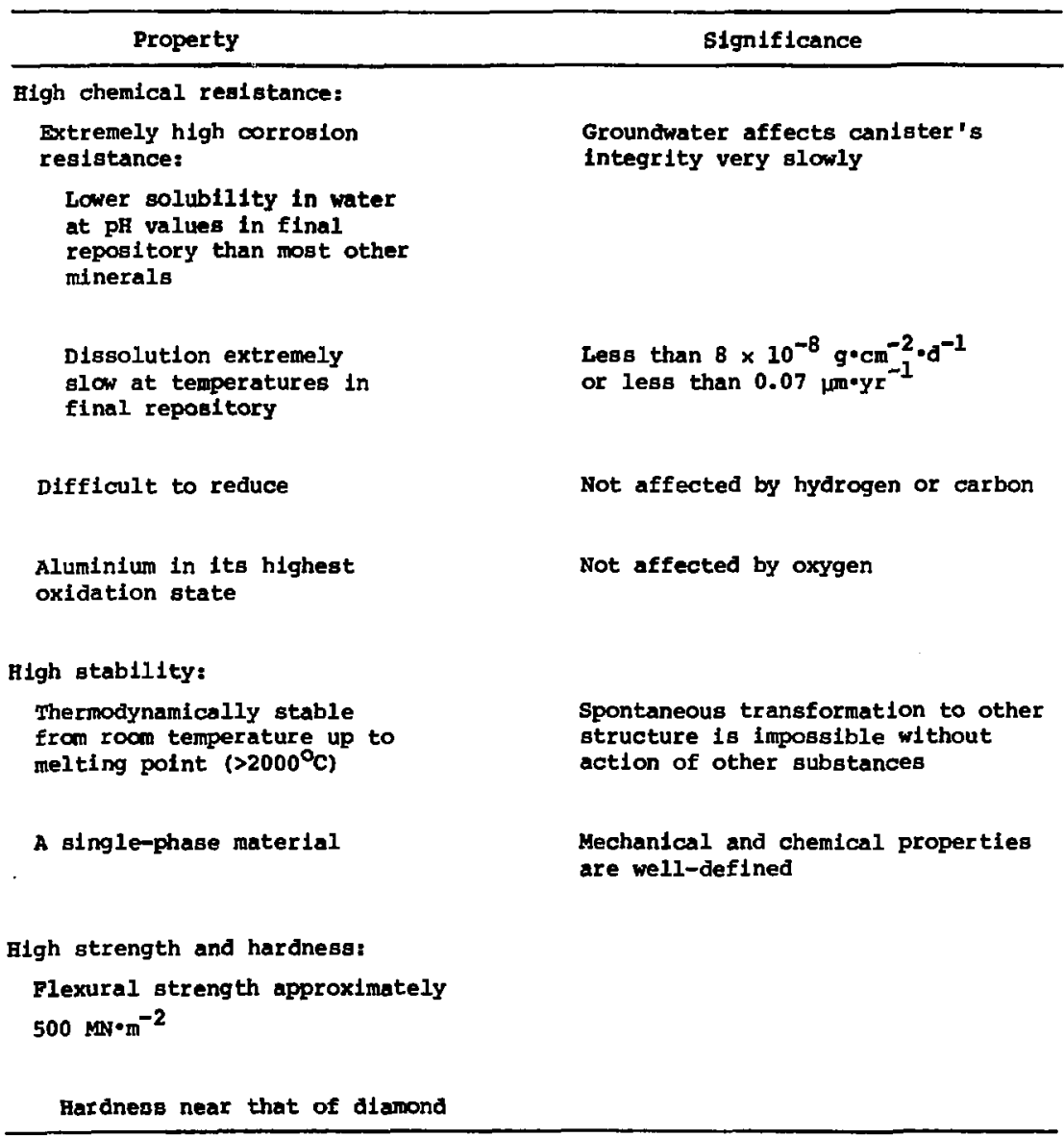


Parliament had decided on earlier the same year. The expenses for the councll are paid by the nuclear power utilities, but administered by the Government Department of Energy. The present annual budget approaches $13 \mathrm{Mkr}$ (about $\$ 3.5$ niliton).

When the KBS program began in late 1976, it became necessary to coordinate the activities of KBS and PRAV. Because the kBS project was supposed to be intensive but short term, the PRAV program was concentrated on more long-range aims. However, both programs have supported short- as well as long-term projectg in rather close cooperation. The approximately 30 research and development projects are running on ad-hoe time schedules and are contracted in consecutive ateps as appropriate in each case.

PRAV's present operating plan, carried out by researchers from studsvik Energiteknik $A B$, the Swedish Geological Survey, and a number of universities, pertains to the following areas of Interest:

- Handling of low-level and moderately radioactive reactor wastes. The goals are volume reduction of the bulky waste and separation of long-lived radionuclides for separate handling.

- Transport and central storage of used reactor fuel and worn-out reactor componenta. The goal is to have a central facility for apent fuel storage and a supporting transport system in use by about 1985.

- Recycling of used reactor fuel and conversion of hot waste to solid form.

- Final storage of waste in rock formations. Initial effortb are directed to locating rock formations with few cracks and low groundwater tablea, to developing technigues for measuring the age and mobility of groundwater at depths frcm 100 to $1000 \mathrm{~m}$, and to determining materials and methods which are nost suitable for packaging waste materials for geologic storage.

- Renoval of actinides from high-level waste from spent fuel reproceseing (actinide fractionation). This program ended in June 1981.

- Bazard evaluation nodels for the above aspects of waste managenent. The major research and develogment projects are further specified below:

\section{Reactor wate handling, transport, and disposal}

- Concoptual design of a medium level waste disposal facility in a rock cavern. 
- Sea transport syotem for mediur- and low-level waste from nuclear plants to disponal facility.

- Pathway analyais for nuclide migration from waste bodies to the biosphere.

- Hazard evaluation for sea trensport of waste.

Treatment methods of medium and low-level waste

- Development of Inorganic ion-exchange resing (zeolites, titanates).

- Pilot testg on transfer of nuclides from contaninated waste (e.g., organic filter resins) to Inorganic ion exchangers.

- Sintering of inorganic lon-exchange resins to ceramic bodies.

- Fluldized bed incineration of organic lon-exchange resins.

- Investigations on long-term storage properties of concrete as matrix and encapsulation for waste.

Flnal disposal of high-level waste

- Surveying of suitable rock formations.

- Evaluation of geophyalcal logging technigues.

- Chemical equilibria and radionuclide sorption on bedrock material in interaction with groundwater.

- Sorption mechanlams in rock fissures.

- In situ studies of radionuclide migration in fissured bedrock in Studsvik.

- Investlgations of fissure mineralogy.

On July 1, 1981, PRAV ceased to exist. Ongoing research is belng taken over by SKBE/KBS, under supervision of the new organization, NÄBAB. The expected budget for the program is about $\$ 10$ million. 


\section{APPEANDIX A}

\section{LIST OF KBS TECHNICAL REPORTS}

01 Källatyrkor i utbränt bränsle och högaktivt avfall från en PWR beräknade med ORIGEN

("Emission rates in spent fuel and high-level waste from a PWR, calculated using ORIGEN")

Nils Kjellbert

AB Atomenergi, 1977-04-05

02 PM angående värmeledningstal hos jordmaterial

("Memorandum concerning the thermal conductivity of soil")

Sven Knutsson

Roland Pusch

Luleå Institute of Technology, 1977-04-15

03 Deponering av högaktivt avfall i borrhål med buffertsubstans

("Deposition of high-level waste in boreholes containing buffer material")

Arvid Jacobss on

Roland Pusch

Luleå Institute of Technology, 1977-05-27

04 Deponering av högaktivt avfall i tunnlar med buffertsubstans ("Deposition of high-level waste in tunnels containing buffer material")

Arvid Jacobsson

Roland Pusch

Luleå Institute of Technology, 1977-06-01

05 Orienterande temperaturberäkningar för slutförvaring $i$ berg av radioaktivt avfall, Rapport 1

("Preliminary temperature calculations for the final storage of radioactive waste in rock, Report $1^{\prime \prime}$ )

Roland Blomquist

AB Atomenergi, 1977-03-17

06 Groundwater movements around a repository, Phase 1, State of the art and detailed study plan

Ulf Lindblom

Hagconsult AB, 1977-02-28

07 Resteffekt otudier för KBS ("Decay power studies for KBS")

Del 1 Litteraturgenomgäng ("Part 1 Review of the literature")

Del 2 Berikningar ("Part 2 Calculations")

Kim Ekberg

Nils Kjellbert

Göran $01 \mathrm{ss}$ on

AB Atomenergi, 1977-04-19 
08 Utlakning av franskt, engelskt och kanadensiskt glas med högaktivt avfall

("Leaching of French, English and Canadian glass containing high-level waste")

Göran Blomqvist

AB Atomenergi, 1977-05-20

09 Diffusion of soluble materials in a fluid filling a porous medium

Hans Häggblom

AB Atomenergi, 1977-03-24

10 Translation and development of the BNWL-Geosphere Model

Bertil Grundfelt

Kemakta Konsult AB, 1977-02-05

11 Utredning rörande titans lämplighet som korrosionshärdig kapsling för kärnbränsleavfall

("Study of suitability of titanium as corrosion-resistant cladding for nuclear fuel waste")

Sture Henriksson

AB Atomenergi, 1977-08-24

12 Bedömning av egenskaper och funktion hos betong i samband med dlutlig förvaring av kärnbränsleavfall i berg ("Evaluation of properties and function of concrete in connection with final storage of nuclear fuel waste in rock")

Sven G Bergström

Göran Fagerlund

Lars Rombén

The Swedish Cement and Concrete Research Institute, 1977-06-22

13 Urlakning av använt kärnbränsle (bestrålad uranoxid) vid direktdeponering

("Leaching of spent nuclear fuel (irradiated uranium oxide) following direct deposition")

Ragnar Gelin

AB Atomenergi, 1977-06-08

14 Influence of cementation on the deformation properties of bentonite/quartz buffer substance

Roland rusch

Lulea Institute of Technology, 1977-06-20

15 Orienterande temperaturberäkningar för slut förvaring $i$ berg av radioaktivt avfall, Rapport 2

("Preliminary temperature calculations for the final storage of radioactive waste in rock, Report 2")

Roland Blomqvist

AB Atomenergi, 1977-05-17 
16 Översikt av ut ländaka riskanalyser samt planer och projekt rörande slut förvaring

("Review of foreign risk analyses and plans and projects concerning final storage")

Ake Hultgren

$A B$ Atomenergi, August 1977

17 The gravity field in Fennoscandia and postglacial crustal movements

Arne Bjerhatmanar

Stockholm, August 1977

18 Rörelser och instabiliteter i den suenska berggrunden

("Movements and instability in the Swedish bedrock")

Nils-Axel Mörner

University of Stockholm, August 1977

19 Studier av neotektonisk aktivitet i mellersta och norra Sverige, flygbildsgenomgång och geofysisk tolkning av recenta förkastningar

("Studies of neotectonic activities in central and northern Sweden, review of aerial photographs and geophysical interpretation of recent faults")

Robert Lagerbäck

Herbert Henkel

Geological Survey of Sweden, September 1977

20 Tektonisk analys av södra Sverige, Vättern - Norra Skăne

("Tectonic analysis of southern Sweden, Lake Vättern Northern Skåne")

Kennert Röshoff

Erik Lagerlund

University of Lund and luleg Institute of Technology, September 1977

21 Earthquakes of Sweden 1891 - 1957, $1963-1972$

Ota Kulhánek

Rutger Wahlström

University of Uppsala, September 1977

22 The influence of rock movement on the stress/strain situation in tunnels or boreholes with radioactive canisters embedded in a bentonite/quartz buffer mass

Roland Pusch

Lulea Institute of Technology, 1977-08-22

23 Water uptake in a bentonite buffer mass

A model study

Roland Pusch

Lulea Institute of Technology, 1977-08-22 
24 Beräkning av utlakning av vissa fissiósprodukter och aktinider frân en cylinder av franakt glas

("Calculation of leachin; of certain fission producta and actinides from a cylinder made of French glass")

Göran Blomqvist

$A B$ Atomeneiti, 1977-07-27

25 Blekinge kus :gnejs. Geologi och hydrogeologi

("The Blekinge coastal gneiss, Ceology and hydrogeology")

Ingemar Larsson Royal Institute of Technology

Tom Lundgren Swedish Geotechnical Institute

Ulf Wiklander Geological Survey of Sweden

Stockholm, August 1977

26 Bedömning av risken för fördröjt brott i titan

("Evaluation of risk of delayed fracture of titanium")

KjelI Petiersson

AB Atomenergi, 1977-08-25

27 A short review of the formation, stability and cementing properties of natural zrulites

Arvid Jacobsson

Luleă Institute of Technology, 1977-iú-03

28 lärmeledningsförsök på buffertsubstans av bentonit/pitesilt

("Thermoconductivity experiments with buffer material of bentonite/pitesilt")

Sven Knutsson

Lulea Institute of Technology, 1977-09-20

29 Deformationer i sprickigt berg

("Deformations in fissured rock")

Ove Stephansson

Luleå Ins*itute of Tachnology, 1977-09-28

30 Retardation of escaping nuclides from a final depository Ivars Neretnieks

Royal Institute of Technology, Stockholm, 197;-09-14

31 Bedömning av korrosionsbeständigheten hos material avsedda för kapsling av kärnbränsleavfall. Lägesrapport 1977-09-27

samt kompletterande yttranden

("Evaluation of corrosion resistance of material intended

for encapsulation of nuclear fuel waste. Status report, 1977-09-27, and supplementary statemencs")

Swedish Corrosion Research Institute and its reference group

32 Egenskaper hos bentonitbaserat buffertmaterial

("Properties of bentonite-based buffer material")

Roland Pusch

Arvid Jacobsson

Luleå Institute of Technology, 1978-06-10 
33 Required physical and mechanical properties of buffer masses Roland Pusch

Luleå Institute of Technology, 1977-10-19

34 Tillverkning av bly-titan kapsel

("Fabrication of lead-titanium canister")

Folke Sartelin $A B$

VBB

ASEA-Kabel

Swedish Institute for Metals Research

Stockholm, November 1977

35 Project for the handling and storage of vitrified high-level siaste

Saint Gobain Techniques Nouvelles, October 1977

36 Sammansättning av grundvattar. på större djup i granitisk berggrund

("Composition of groundwater deep down in granitic bedrock") Jan Rennerfelt

Orrje \& Co, stockholm, 19?7-11-07

37 Hantering av buffertmaterial av bentonit och kvarts

("handling of buffer material of bentonite and quartz")

Hans Fagerström, VBB

Björn Lundahl, Stabilator

Stockholm, October 1977

38 Ut formning av bergrumsanläggningar

("Design of rock cavern facilities")

Arne Finne, KBS

Alf Engelbrektson, VBB

Stockholm, December 1977

39 Konstruktionsstudier, direktdeponering

("Design studies, direct deposition")

Bengt lönnerberg

ASEA-ATOM, Västerås, September 1978

40 Ekologisk transport och strå Idoser från grundvatcenburna radioakt iva ämnen

("Ecological trasusport and radiation doses from groundwaterborne radioact; - a substances")

Ronny Bergman

Ulla Bergetröm

Sverker Evans

AB Atomenergi, 1977-12-20

41 Säkerhet och strålskydd inom kärnkraftområdet.

Lagar, normer och bedömningsgrunder

("Safety and radiation protection in the field of nuclear

nower. Laws, standards and grounds for evaluation")

C.ristina Gyllander

Siegfried $F$ Johnson

Stig Rolandson

$\mathrm{AB}$ Atomenergi and ASEA-ATOM, $1977-10-13$ 
42 Säkerhet vid hantering, lagring och transport av använt kärnbränsle och förglasat högaktivt avfall

("Safely in the handling, storage and transport stion of spent nuclear fuel end vitrified high-level waste")

Ann Margret Ericsson

Kemakta, November 1977

43 Transport av radioaktiva ämnen med grundvatten från ett bergförvar

("Transport of radioacitve elements in groundwater from a rock repository")

Bertil Grundfelt

Kemakta, 1977-12-13

44 Beständighet hos borsilikatglas

("Durability of borosilicate glass")

Tibor Lakatos

Glasteknisk Utveckling AB, Växjö, December 1977

45 Beräkning av temperaturer i et: envånings slutförvar $i$ berg

för förglasat radioaktivt avfall

("Calculation of temperatures in a single-level final

repository in rock for vitrified radioactive waste")

Report 3

Rol.and Blomquist

AB Atomenergi, $1977-10-19$

46 Temperaturberäkningar för använt bränsle

("Teinperature calculations for spent fuel")

Taivo Tarandi

VBB, June 1978

4? Investigations of groundwater flow in rock around repositories for nuclear waste

John Stokes

Roger Thunvik

Department of agricultural hydrotechnics, Royal Institute

of Technology, 1978-02-28

48 The mechanical properties of the rocks in Stripa, Kråkemåla, Finns $j o ̈$ and Blekinge

Graham Swan

Lulea Institute of Technology, 1977-08-29

49 Bergapänningsmärningar i Stripa gruva

("Measurements of rock atresses in the Stripa mine")

Hans Carlsson

Lules Institute of Technology, 1977-08-29

50 Lakningsförsök med högaktivt franskt glas i studsvik

("Leaching trials with high-level French glass at Studsvik") Göran Blomquist

AB Atomenergi, November 1977 
51 Seismotectonic risk modelling for nuciear waste disposal in the Swedish bedrock

F Ringdal

H Gjöystdal

E S Husebye

Royal Norwegian Council for scientific and industrial research, October 1977

52 Calculations of nuclide migration in rock and porous media penetrated by water

H Häggblom

AB Atomenergi, 1977-09-14

53 Mätning av diffusionshastighet för silver i lera-sandblandning

("Measurement of rate of diffusion of silver in clay-sandmix")

Bert Allard

Heino Kipatsi

Chalmers University of Technology, 1977-10-15

54 Groundwater movements around a repository

54:01 Geological and geotechnical conditions Hăkan Stille Anthony Burgess

Uif $E$ Lindblom

Hagconsult AB, September 1977

54:02 Thermal analyses

Part 1 Conduction heat transfer

Part 2 Advective heat transfer

Joe L Ratigan

Hagconsult AB, September $\$ 377$

54:03 Regional groundwater flow analyses

Part 1 Initial conditions

Part 2 Long term residual conditions

Anthony Burgess

Hagconsult $A B$, Ostober 1977

54:04 Rock mechanics analyses

Joe L Ratigan

Hagconsult AB, September 1977

54:05 Repository domain groundwater flow analyses

Part 1 Permeability perturbations

Part 2 Inflow to repository

Part 3 Thermally induced flow

Joe L Ratigan

Anthony Burgess

Edward L Skiba

Robin Charlwood

Hagconsult AB, September 1977 
55 Sorption av långlivade radionuklider i lera och berg

("Sorption of long-lived radionuclides in clay and rock")

Part 1

Bert Allard

Heino Kipatsi

Jan Rydberg

Chalmers University of Technology, 1977-10-10

56 Radiolys av utfyllnadsmaterial

("Radiolysis of filler material")

Bert Allard

Heino Kipatsi

Jan Rydberg

Chalmers University of Technology, 1977-10-15

57 Stråldoser vid haveri under sfötransport av kärnbränsle

("Radiation doses in the event of a failure during the

transport of nuclear fuel by sea")

Anders Appelgren

U1la Bergström

Lennart Devell

AB Atomenergi, 1978-01-09

58 Strålrikker och högsta tillåtliga străldoser för människan

("Radiation hazards and maximum permissible radiation doses for human beings")

Gunnar Walinder

FOA, Stockholm, 1977-11-04

59 Tectonic Lineaments in the Baltic from Gävle to Simrishamn Tom Flodén

University of Stockholm, 1977-12-15

60 Förarbeten till platsval, berggrundsundersökningar

("Preliminary studies for site choice, bedrock studies")

Sören Scherman

Berggrundvattenförhållanden i Finnsjöområdets nordöstra del ("Groundwater conditions in the northeastern sector of the Finns jö district")

Carl-Erik Klockars

Ove Persson

Geological Survey of Swieden, January 1978

61 Permeabilitetsbestämningar

("Permeability determinations")

Anders $\mathrm{Hult}$

Gunnar Gidlund

Ulf Thoregren 
Geofysisk borrhălsmätning

("Ceophysical borehole survey")

Kurt-Ake Magnusson

Oscar Duran

Geological Survey of Sweden, January 1978

62 Analyser och åldersbestámningar av grundvatten på stora djup

("Analyses and age determinations of groundwater at great depths")

Gunnar Gidlund

Geological Survey of Sweden, 1978-02-14

63 Geologisk och hydrogeologisk grunddokumentation av stripa försöksstation

("Geological and hydrogeological documentation at the Stripa research station")

Andrei olkiewicz

Kenth Hansson

Karl-Erik Almén

Gunnar Gidlund

Geological Survey of Sweden, February 1978

64 Spänningsmätningar i Skandinavisk berggrund - förutsättningar, resultat och tolkning

("Stress measurements in Scandinavian bedrock - premises, results and interpretation")

Sten G A Bergman

Stockholm, November 1977

65 Säkethetsanalys av inkapslingsprocesser

("Safety analysis of encapsulation processes")

Göran Carleson

AB Atomenergi, 1978-01-27

66 Några synpunkter på mekanisk säkerhet hos kapsel för kärnbräng leavfall

(Viewpoints on the mechanical reljability of a canister for nuclear waste")

Fred Nilsson

Royal Institute of Technology, stockholm, February 1978

67 Mätning av galvanisk korrosion mellan titan ocul bly samt mätring av titans korrosionspotential under y-bestrilning ("Measurement of palvanic corrosion between titanium and lead and measurement of corrosion potential of titanium under gamma radiation")

3 technical memorandums

Sture Henriksion

Stefan Potura

Maths Åberg

Derek Lewis

$A B$ Atomenergi, January-February 1978 
68 Degraderingsmekanismer vid bassänglagring och hantering av utbränt kraftreaktorbränsle

("Degradation mechanisms in connection with pool storage and handing of spent nuclear reactor fuel")

Gunnar Vesterlund

Torsten Olsson

ASEA-ATOM, $1978-01-18$

69 A three-dimens: onal method for cilculating the hydraulic gradient in porous and cracked adia

Hans Häggblom

AB A tomenergi, $1978-01-26$

70 Lakning av bestrålat $\mathrm{vO}_{2}$-bränsle

("Leaching of irradiated $\mathrm{UO}_{2}$ fuel")

Ulla-Britt Eklund

Ronald Forsyth

AB atomenergi, 1978-02-24

71 Bergspricktätning med bentonit

("Rock fissure sealing with bentonite")

Roland Pusch

Luleg Institute of Technology, 1977-11-16

72 Vàrmeledningsförsök på buffertsubstans av kompakterad bentonit

('Thermal conductivity tests on buffer material of compacted bentonite")

Sven Knutsson

Luleå Institute of Technology, 1977-11-18

73 Self-injection of highly compacted bentonite into rock

jointe

Roland Pusch

Luleå Institute of Technology, 1978-02-25

74 Highly compacted Na bentonite as buffer substance

Roland Pusch

Luleå Institute of Technology, 1978-02-25

75 Small-scale bentonite injection test on rock

Roland Pusch

Lulea Institute of Technology, 197B-D3-02

76 Experimental determination of the stress/strain situation

in a sheared cunnel model with cainster

Roland Pusch

Luleå Institute of Technology, 1978-03-02

77 Nuklidvandring från ett bergförvar för utbränt bränele

("Nuclide migration from a rock repository for spent fuel")

Bertil Grundfelt

Kemakt a konsult AB, stockholm, 1978-08-31 
78 Bedömning av radiolys i grundvatten

("Evaluation of radiolysis in groundwater")

Hilbert Chrigtenssen

AB Atomenergi, 1978-02-17

79 Transport of oxidants and radianuclides through a clay barrier

Ivars Neretnieks

Royal Institute of Technology, Stockholm, 1978-02-20

80 Utdiffusion av svårlösliga nuklider ur kapsel efter kapse 1genombrot $t$

("Diffusion of poorly soluble nuclides 1 , th a canister

following canister penetration")

Karín Andersson

Ivars Neretnieks

Royal Institute of Technology, Stockholm, 1978-03-07

81 Tillverkning av kopparkapsel för slut förvaring av använt bräns le

("Fabrication of copper canister" for final storage of spent nuclear fuel")

Jan Bergström

Lennar t Gillander

Kåre Hannerz

Liberth Karlsson

Bengt Lönnerberg

Gunnar Nilsson

Sven olsson

Stefan Sehlstedt

ASEA, ASEA-ATOM, June 1978

82 Hantering och slutförvaring av aktiva metalldelar

("Handling and final storage of radioactive metal components")

Bengt Lönnerberg

Alf Engelbrektsson

Ivars Neretnieks

ASEA-ATOM, VBB (The Swedish Hydraulic Engineering Co., Ltd.),

Royal Institute of Technology, June 1978

83 Hantering av kapslar med använt brönsle i slutförvaret

("Handling of canisters for spent fuel in the final

repository")

Alf Engelbrektsson

VBB (The Swedish Hydraulic Engineering Co., Ltd.), April 1978

B4 Tillverkning och hantering av bentonitblock

("Fabri-ation and handing of bentonite blocks")

Alf Engelbrektsson et al

VBB, ASEA, ASEA-ATOM, Gränges Mineralprocesser, June 1978 
85 Beräkning av kryphastiglute hos ett blyhölje innehållande en glaskropp under inverkan av tyngdkraften

("Calculation of the creep rate of a lead jacket con-

taining a glass body under the influence of gravity")

Anders Samuelsson

Förändring av krypegenskaperna hos ett blyhölje som följd av en mekanisk skada

("AIteration of creep properties of a lei jacket as a result of mechanical damage")

Göran Eklund

Institute of Metals Research, September 1977 - April 1978

86 Diffusivitetsmätningar av metan och väte i våt lera

("Diffusivity measurements of methane and hydrogen in

wet clay")

Ivars Neretnieks

Christina Skegius

Royal Institute of Technology, Stockholm, 1978-01-09

87 Diffusivitetsmätningar i våt lera Na-lignosulfonat, $\mathrm{Sr}^{2+}$, $\mathrm{Cs}^{+}$

(" $\not j$ fusivity measurements in wet clay, Na-lignosulphonate $\mathrm{Sr}^{2 \neq}, \mathrm{Cs}^{+\prime)}$

Ivars Neretnieks

Christina Skagius

Royal Institute of Technology, Stockholm, 1978-03-16

88 Groundwater cheristry at depth in granites and gneisses Cunnar Jacks

Royal Institute of Technology, Stockholm, April 1978

89 Inverkan av glaciation på deponeringsanlïggning belägen

$i$ urberg $500 \mathrm{~m}$ under markytan

("Influence of glaciation on a waste repository situated

in primary bedrack $500 \mathrm{~m}$ below the surface of the ground")

Roland Pusch

Luleå Institute of Technology, 1978-03-16

90 Copper as an encapsulation material for unreprocessed nuclear waste - evaluation from the viewpoint of corrosion Final report, 1978-03-31

The Swedish Corrosion Research Institute and its reference group

91 Korttidsvariationer i grundvattnets trycknivå

("Short-term variations in the pressure level of the groundwater")

Lars $Y$ Nilsson

Royal Institute of Technology, Stockholm, September 1977

92 Termisk utvidgning hos granitoida bergarter

("The rmal expansion of granitoid rocks")

Ove Stephansson

Lulei Institute of Technology, April 1978 
93 Preliminary corrosion studies of glass ceramic code 9617 and a sealing frit for nuclear waste canisters

I D Sundquist

Corning Glass Works, 1978-03-14

94 Avfallsströmmar i upparbetningsprocessen

("Waste flows in reprocessing")

Birgitta Andersson

Ann-Margret Ericsson

Kemakta, March 1978

95 Separering av $\mathrm{C}-14$ vid upparbetningsprocessen

("Separation of $\mathrm{C}-14$ in reprocessing")

Sven Brandberg

Aun-Margret Ericsson

Kemakta, March 1978

96 Korrosionsprovning av olegerat titan i simulerade depuneringsmiljöer för upparbetat kärnbränsleavfall

("Corrosion testing of unalloyed titanium in simulated deposition environments for reprocessed nuclear fuel waste") Sture Henriksson

Marian de Pourbaix

AB Atomenergi 1978-04-24

97 Colloid chemical aspects of the "confined bentonite concept" Jean $C$ Le Bell

Institute of Surface Chemistry, 1978-03-07

98 Sorption av långlivade radionuklider i lera och berg Del 2

("Absorption of long-lived radio nuclides in clay and

rock Part 2")

Bert Allard

Heiro Kipatsi

Börje Torstenfelt

Chalmers University of Technology, 1978-04-20

99 Lakning av hügaktivt franskt glas

("Leaching of high-level radioactive French glass").

Status report $1978-06-01$

Cöran Blomquist

AB Atomenergi, 1978-06-19

100 Dos och dosinteckning frăn grumdvattenburna radioaktiva ämnen vid slut förvaring av använt kärnbräns le

("Dose and dose committment from groundwater-borne radioactive elements in the final storage of spent nuclear fue 1 ")

Ronny Bergman

Ulla Bergström

Sverker Evans

AB Atomenergi, 1978-10-06 
101 Urläckning av Ni-59 från ett bergförvar

("Leakage of Ni-59 from a rock repository")

Ivars Neretnieks

Karin Andersson

Lennart Henstam

Royal Institute of Technology, Stockholm, 1978-04-24

102 Metod att bocka bestrălade bränslestavar

("Method for bending irradiated fuel rods")

Torsten 01sson

ASEA-ATON, 1978-03-29

103 Some aspects on colloids as a means for transporting

nuclides

Ivars Neretnieks

Royai Institute of Technology, Stockholm, 1978-08-08

104 Finit elementanalys av bentonitfyllt bergförvar

("Finice element analysis of bentonite-filled rock repository")

Ove Stephansson

Kenneth Mäki

Tommy Groth

Per Johansson

Lulea Institute of Technology, July 1978

105 Neutroninduceraj aktivitet i bräns leelementdetaljer

("Neutron-induced radi acitvity in fuel assembly components")

Nils A Kjellbers

AB Atomenergi, 1978-03-j'

106 Strålningsnivå och till vatten deponerad strålningsenergi utanför kapslar i slutförvaret

("Radiation level and radiant energy imparted to water outside of canisters in the final repository")

Klas Lundgren

ASEA-ATOM, 1978-05-29

107 Blyinfodrad titankapsel för upparbetat och glasat kärnbräns leavfall - Bedömning ur korrosionssynpunkt

("Lead-lined titanium -2nister for reprocessed and vitrified nuclear fuel waste - Evaluation Erom the viewpoint of

corrosion")

'he Swedish Cortosion Institute and its reference group

Final report

1978-05-25

108 Criticality in a spent fuel repustory in wet crystalline rock

peter Behrenz

Kåre Hannerz

ASEA-ATON, 1978-05-30 
109 Lakningsbar spaltaktivitet

("Leachable gap activity")

Lennart Devell

Rolf Hesböl

$A B$ Acomenergi, October 1978

110 In situ experiments on nuclide migration in fractured crystalline rocks

Ove Landström

Carl-Erik Klockars

Karl-Erik Holmberg

Stefan Westerberg

Studsvik Energiteknik and

The Geological Survey of Sweden

July $19 ? 8$

111 Nuklidhalter i använt LWR-bränsle och i högaktivt avfall från Gtercykling av plutonium i P'WR

("Nuclide levels in spent LWR fuel and in high level waste from the recycling of plutonium in "'WR")

Nils Kjoluberg

$A B$ Atomenergi, 1978-07-26

112 Säkerhetsanalys av hanteringsfärfarandet vid inkapsling av utbränt bränsle i kopparkapse?

("Safety anolysis of the handis sedure in the

encapsulation of spent fuel in $c_{1}$. . canisters")

Erik Nordes jö

ASEA-ATOM, 1978-03-20

113 Studier av keramiska material för iıkapsling av höga'ctivt avfall

("Studies of ceramic material for encat sulation of high-

-level waste")

Lei nart Hydën et al

ASt - A'TOM, Septumber 1978

$114 \gamma$-radiolysis of organic compounds and a-radiolysis of water Hilbert Christensen

Studsvik Energiteknik AB, 1978-09-07

115 Accelerc:ad utlösning av uran frătı ta-aktivt $\mathrm{UO}_{2}$

("Accelerated dissolution of uranium from a-active $\mathrm{UO}_{2}$ ")

Gösta Nilsson

Studsvik Energiteknik $A B, 1978-04-27$

116 Lakning av $\mathrm{Al}_{2} \mathrm{O}_{3}$ under simulerande depuneringsbetingelser ("Leaching of $\mathrm{Al}_{2} \mathrm{O}_{3}$ under silnulated repositary conditions") Britt-Marie Svensson

Lennart Dah 1

Studsvik Energiteknik AB, 1978-06-02 
117 Lakning av $\mathrm{Al}_{2} \mathrm{O}_{3}$ i dubbelalestillerat vatten

("Leaching of $\mathrm{Al}_{2} \mathrm{O}_{3}$ in twice-distilled water")

Brict-Marie Svensson

Göran Blonquist

Studsvik linergiceknik AIb, 1978-05-29

118 Slutrapport $\mathrm{Al}_{2} \mathrm{O}_{3}$ kapsel

("Final report on $\mathrm{Al}_{2} \mathrm{O}_{3}$ canister")

The Swedish Corrosion Institute and its reference group

119 Slutförvaring dv aktiverade staldetaljer i betong

("Final storage of activated steel components in concrete")

Lars Rombén

Kyösti luutti

The Swedish Cement and Concrete Rescurch Institute,

1978-07-14

120 Some notes in connection with the KBS studies of final

disposal of spant fuel

Ivars Neretnieks

Royal Institute of Technology, Sepcemider 1978 
$1977-78$

121

RBS Technical Reports 1 - 120.

Sumaries. Stockholm, May 1979

1979

79-01 clay particle redistribution and piping phencma in bentonite/ guartz buffer material due to high hydraulle gradients Foland Pusch

University of Lulea 1979-01-10

79-02 Försöksomrădet vid Finnsjön

Bzskrivning till berggrunds- och jordartskartor

Karl-Erik Almén

Lennart Ekman

Andrzej Olkiewicz

Sver $+g e s$ Geologiska Undersökning November 1978

79-03 Bergmekanisk bedömning av temperaturbelastning vid slutförvaring av radioaktivt avfall 1 berg

Ove Stephansson

Bel.gt Leijon

Högskolan i Lule: 1979-01-10

79-04 Temperatur- och spïnningsberäkning för slutförvar

Taivo Tarandi

VBB Vattenbyggnadsbyrån, stockhola februari 1979

79-05 Rompletterande berggrundsundersökningar inom Finnsjö- och

Rar lshamnsouridena

Andrzef olkiewicz

Soren Scherman

Rarl-kxel Kornfalt

Sveriges Geologiska Undersökning 1979-02-02

79-06 Romplatterande permeabilitetanatningar 1 karlshannsomradet

Gunnar Gidlund

Renth Hansson

Ulf Thoregren

Sveriges Geologiska Undersökning februari 1979

79-07 Reial hos berggrundvatten i Blekinge

Gunnar Jacks

Institutionen för Rulturteknik, RTH, februar1 1979

79-08 Beräkningar av grundvattenröreleer inom sternochrådet 1 Blekinge John stoken

Intitutionen för Rulturteknik, RTH, februar1 1979

Preliainas utgåva 
79-09 Utvärdering av de hydrogeologlska och berggrundsgeologiska förhallandena pá sternö

Kaf Ahlbom

Leif Carlgson

Gunnar Gidlund

C-E RIockars

Sören Schernan

Ulf Thore:-en

Sveriges Geologiska Under ab̈kn1ng, Berggrundabyrån, februar1 1979

79-10 Model calculations of groundwater condition on Sternö peninsula Carl-Linart Axelsson

Leif Carlsson

Geological Survey of Sweden september 1979

79-11 Tolkning av permeabllitet 1 en befintling berganläggning

Ulf Lindblon

Alf Norlén

Tesús Granero

Kent Adolfsson

Hagconsult AB februari 1979

79-12 Geofys1sk borrhalmätning 12 st borrhal på 5 tenö

Rurt-Ake Magnusson

Oscar Duran

Sveriges Geologiaka Undersökning februari 1979

79-13 Blldning av fritt väte vid radlolys 1 lerbädd

Trygue Eriksen

Johan IInd

Institutet för kärnkemi RTH 1979-03-28

79-14 korrosionsprovning av olegerat titan " simulerade deponeringamiljoër för uppar betat kärnbränsleavfall

slutrapport

Sture Benr1kgon

Marlan de Pourbalx

Studevik Energ1teknik AB 1979-05-07

79-15 Kostnader för hantering och slutförve: ing av högaktivt avfall och anvïnt kärnbränsle

Arne Finné

Rke Larson Byggaze, april 1979

79-16 Berikning av permeabllitet 1 stor skala vid bergrum 1 Karlshamns hawn

vif Lindblom

$J$ J Granero

79-17 Water percolation effects on clay-poor bentonite/quartz buffer aterlal at high hydraulic gradients

R Pusch

D1v. Soll Mechanics, University of Lulea, 1979-05-31 
79-18 Sammanställning och utvärdering av genconförda GEroUT- och BIOPATA-körningar

M Elert

B Grundfelt

C stenquist

Remakta AB, Studavik Energiteknik AB, 1979-08-13

79-19 Diffusion in the rock matrix - An important factor in radionuclide retardation?

Ivars Ner etnieks

Royal Instltute of rechnology May 1979

79-20 Hydraulisk konuktivitet beständ 1 stor skala 1 ytliga partier

av Blekinge kustgnejs

Ulf IIndblom, Hagconsult AB, Göteborg

Torbjörn Hahn, Fortlfikationgförvaltnıngen, Stockho̊lm

Göteborg jun1 1979

79-21 Teknik och kostnad för rivning av svenska kärnkraftverk

Utarbetad av en särskild arbetsgrupp inom SRBF/RBS,

oktober 1979

79-22 Technology and costs for dismantling a Swedish nuclear power plant. Prepared by a speclal working group within SKBF/RBS,

October 1979

79-23 Release of ${ }^{129}$ I to the coolant

Bilbert Christensen

Studsvik Energiteknik AB 1979-07-20

79-24 Development of glass compositions with 98 waste content for the vitrification of high-level waste from LwR nuclear reactors Tibor Lakatos

Swedish Glass Research Institute, växjö October 1979

79-25 Svenska torv- och lerlager - Egenskaper av betydelse för slutlagring av lig- och medelaktivt avfall

Ove Landstrom

Hans Tollbäck

Studsvik Energiteknik AB, November 1979

Miktiga lerformationer 1 Sydsverige - En litteraturstudie Henr $1 k$ Nor lander

kvartärgeologiska Institutionen

Stockholms Universitet, September 1979

79-26 Leakage of Niobium-94 from an Underground Rock Repository

$x$ Anderseon

B Toritenfelt

J Rydberg

Department of Niclear Chemistry

Chalmers Untverstty of Technology, 1979-11-05 


\section{LIST OF KBS TECHNICAL REPORTS 1980}

Microflche coples of reports are available from

INIS CLEARINGHOUSE

International Atomic Energy Agency P O Box 590

A-1011 VIENNA, AUSTRIA

Report No.

List of the Technical Reports

$1977-78$

TR 121 KBS Technical Reports 1 - 120. Summaries. Stockholm, May 1979.

\section{$\underline{1979}$}

TR 79-28 The KBS Anrual Report 1979. KBS Technical Reports 79-01--79-27. Summaries. Stockholm, March 1980.

\section{0}

*) TR 80-01 Komplettering och sammanfattning av geohydrologiska undersökningar inom sternöområdet, Karlshamn

("Supplementary and concluding geohydrological investigations within the Sternö area in Karlshamn") Lennart Ekman Bengt Gentzschein

Sveriges geologiska undersökning, mars 1980

*) = In Swedish 
Report No.

List of the Technical Reports

TR 80-02 Modelling of rock mass deformation for radioactive waste repositories in hard rock

Ove Stephansson

Per Jonasson

Department of Rock Mechanics

University of Lulea

Tommy Groth

Department of Soll and Rock Mechanics

Royal Institute of Technology, Stockholm

1980-01-29

TR 80-03 GETOUT - a one-dimensional model for groundwater transport of radionuclide decay chains

Bertil Grundfelt

Mark Elert

Kemakta konsult AB, January 1980

TR 80-04 Helium retention

Summary of reports and memoranda

Gunnar Berggren

Studsvik Energiteknik $\mathrm{AB}$, 1980-02-14

TR 80-05 On the description of the properties of fractured rock using the concept of a porous medium John Stokes

Royal Institute of Technology, Stockholm 1980-05-09

*) TR 80-06

Alternativa ingjutningstekniker för radioaktiva jonbytarmassor och avfallslösningar

("Alternative methods for soliaification of ion

exchange resins and waste solutions")

Claes Thegerström

Studsvik Energiteknik AB, 1980-01-29

TR 80-07 A calculation of the radioactivity induced in

PWR cluster control rods with the origen and

casmo codes

Kim Ekberg

Studsvik Energiteknik AB, 1980-03-12

TR 8O-OB Groundwater dating by means of isotopes

A brief review of methods for dating old groundwater by means of isotopes

A computing model for carbon - 14 ages in groundwater Barbro Johansson 
Report No. List of the Technical Reports

TR 80-09 The Bergshamra earthquake sequence of December 23, 1979

Ota Kulhánek, Norris John, Klaus Meyer, Torild van Eck and Rutger Wahlström

Seismological Section, Uppsala University Uppsala, Sweden, August 1980

*) TR 80-10 Kompletterande permeabilitetsmätningar 1 finnsjoomrảdet

("Supplementary geohydrological investigations in the Finnsjo area")

Leif Carlsson, Bengt Gentzschein, Gunnar Gidlund, Kenth Hansson, Torbjorn Svenson, ulf Thoregren

Sveriges geologiska undersökning, Uppsala, maj 1980

TR 80-11 Water uptake, migration and swelling characteristics of unsaturated and saturated, highly compacted

bentonite

Roland Pusch

Luleå 1980-09-20

Division Soll Mechanics, University of Luleá

TR 80-12 Drilling holes in rock for final storage of spent nuclear fuel

Gunnar Nord

Swedish Detonic Research Foundation

I'R 80-13 Swelling pressure of hlghly compacted bentonite Roland Pusch

Division Soil Mechanics, University of Luleá

Lulea 1980-08-20

TR-80-14 Properties and long-term behaviour of bitumen and radioactive Mste-bitumen mixtures

Hubert Eschrich

Eurochemic, Mol, October 1980

T'F 80-15 Aluminium oxide as an encapsulation material for unreprocessed nuclear fuel waste - evaluation from the viewpoint of corrosion

Final Report 1980-03-19

Swedish Corrosion Institute and its reference group

TR 80-16 Permeability of highly compacted bentonite Roland Pusch

Division Soil Mechanics, University of Lulea 1980-12-23

*) = In Swedish 
Report No. List of the Technical Reports

TR 80-17 Input description for BIOPATH

Jan-Erik Marklund

Ulla Bergström

Ove Edlund

Studsvik Energiteknik AB, 1980-01-21

*) TR 80-18 Införande av tidsberoende koefficientmatriser 1 BIOPATH

("Introduction of time independent coefficient matrices in BIOPATH")

Jan-Erik Marklund

Studsvik Energiteknik $A B$, januari 1980

TR 80-19 Hydrothermal conditions around a radioactive waste repository

Part 1 A mathematical model for the flow of groundwater and heat in fractured rock

Part 2 Numerical solutions

Roger Thunvik

Royal Institute of Technology, Stockholm, Sweden

Carol Braester

Israel Institute of Technology, Haifa, Israel

December 1980

*) TR 80-20 BEGAFIP. Programvård, utveckling och benchmarkberäkningar

("BEGAFIP. Program updating, development and bench mark calculations")

Goran Olsson

Peter Hägglöf

Stanley Svensson

Studsvik Energiteknik AB, 1980-12-14

TR 80-21 Report on techniques and methods for surface characterization of glasses and ceramics

Bengt Kasemo

Mellerud, August 1980

TR 80-22 Evaluation of five glasses and a glass-ceramic for solidification of Swedish nuclear waste

Larry L Hench

Ladawan Urwongse

Ceramics Division

Department of Materials Science and Engineering

University of Florida, Gainesville, Florida

1980-08-16

$\bar{\hbar}=$ In Swedish 
TR 80-23 Exact solution of a model for diffusion in particles and longltudinal dispersion in packed beds Anders Rasmuson Ivars Neretnieks

Royal Institute of Technology, August 1979

TR 80-24 Migration of radionuclides in fissured rock - The influence of micropore diffusion and longitudinal dispersion Andcrs Rasmuson Ivars Neretnieks

Royal Institute of Technology, December 1979

TR 80-25 Diffusion and sorption in particles and twodimensional dispersion in a porous media Anders Rasmuson

Royal Institute of Technology, January 1980 
INDUSTRIAL AND CONSULTING COMPANIES

$\mathrm{AB}$ Atomenergi (=Atomic Energy Company of Sweden)

Ahlsell $A B$

ASEA

ASEA-ATOM AB

ASEA-Hafo $A B$

ASEA-Kabe1 $\mathrm{AB}$

Avesta Jernverk's $\mathrm{AB}$

$A B$ Exportsprăk

Forsgren Produltion $A B$

The Mining Industries' Work Study and Consultancy Programme Gränges Mining Mineral Process Laboratory

Hagby Bruk $A B$

$H$ Folke Sandelin $A B$

Hagconsu1t $\mathrm{AB}$

Hydroconsult $\mathrm{AB}$

IFö Electric Högspänning $A B$

IPA-Konsult

Kemakta Konsult $\mathrm{AB}$

Orrje \& Co $A B$, Ingenjörsfirman

Salénrederierna $A B$

Stabilator AB

The National Swedish Institute for Materials Testing

Ställbergs Grufveaktiebolag

The Swedish Academy of Engineering Sciences

Teleplan $A B$

$A B$ Vat tenbyggnadsbyrån

WP-system $A B$

INSTITUTIONS OF HIGHER LEARNING

University of Lund

Division of quarternary geology

E Lagerlund, Ph.D.

University of Gothenburg

Division of marine microbiology Professor K Gundersen 
University of Stockholm

Arrenius Laboratory

Department of geology

Department of microbial geochemistry

University of Uppsala

Department of Seismology

Swedish University of Agriculture

Department of chemistry

Lund Institute of Technology

Department of inorganic chemistry

Chalmers University of Technology

Department of geology

Department of nuclear chemistry

Department of engineering metals

Department of inorganic chemistry

Royal Institute of Technology

Department of mining

Department of physical chemistry

Department of geodesy

Department of chemical engineering

Department of land improvement and drainage

Department of nuclear chemistry

Department of inorganic chemistry

Department of applied elcctro-

chemistry and corrosion science

University of Luleå

Division of -ock mechanics

Division of geotechnics
T Wadstēn, Ph.L.

Dr. N-A Mörner

T Flodén, Ph.L.

Dr. $\mathrm{R}$ Hallberg

Dr. o Kulhànek

Professor I Lindquist

Dr. Sten Andersson

L Bergström, Ph.D. Professor J Rydberg B Allard, D. Eng.

Dr. I Olefjord

Professor $\mathrm{N}-\mathrm{G}$ Vannerberg

Professor I Janelid

Dr. C Leygraf

Professor A Bjerhammar

Professor I Neretnieks

Professor Y Gustafsson

Professor I Larsson

Dr. T E Eriksen

Professor I Grenthe

Professor G Wranglên

Professor U Stepharisson

Dr. K Röshoff

Professor $R$ Pusch

A Jacobsson, Ph.D. 
OTHER INSTITUTIONS

Cement and Concrete Research

Professor S G Bergström

Institute, Stockholm

National Defence Research Institute,

5 Walinder

Stockholm

$\mathrm{L} H$ Andersson

Glass Research Institute, Växjö

B Simningsköld, Lic. Eng .

T Lakatos, Ph.D.

Institute for Metals Research

G Eklund, D.Eng.

Swedish Corrosion Institute,

Stockholm

Swedish Silicate Institute,

Gothenburg

Tandem accelerator laboratory in

Uppsala

Geological Survey of Sweden

Professor E Mattsson

L Ekbom; Lic. Eng.

R Carlsson, Lic. Eng.

Professor A Johansson

Institute of Surface Chemistry

Dr. O Brotzen

$\mathrm{U}$ Thoregren, $\mathrm{Ph} . \mathrm{L}$.

Dr. P Stenius

J 1e Bel1, Lic.Eng.

EXPERTS AND RESEARCH WORKERS

Dr. Sten G A Bergman

Claes Helgesson, D. Eng.

Dr. Peter Fritz

FOREIGN ORGANIZATIONS AND COMPANIES

The Risö Research Station

ROSKILDE, Denmark

Royal Norwegian Council for Scientific

and Industrial Research

KJELLER, Norway

Frauenhofer-Gesellschaft

Institut für Silicatforschung

WüRZBURG, West Germany

Lehrstuhl für Glas und Keramik

Institut für Steine und Erder

CALUSTAHL-ZELLEFELD, West Germany

Saint Gobain Techniques Nouvelles

PARIS, France

COGEMA

PARIS, France

University of Western Ontario

Professor W Fyfe

LONDON, Ontario, Canada 
Corning Glass Works

CORNING, New York, USA

Electric Power Research Institute.

PALO ALTO, California, USA

Department of Energy

WASHINGTON D.C., USA

Dr. Ralph E Grim

URBANA, I11inois, USA

Lawrence Berkeley Laboratory

University of California

BERKELEY, California, USA

Nuclear Regulatory Comnission

WASHINGTON D, C., USA

Office of Waste Isolation

Union Carbide Corp.

OAK RIDGE, Tennessee

Personnel from the Swedish State Power Board, Oskarshamnsverkets Kraftgrupp $A B$ (OKG), the Swedish Nuclear Fuel Supply Company (SKBF), the Swedish Central Power Supply Board (CDL) and the National Council for Radioactive Waste Management (PRAV) have also contributed their services to KBS. The project has organized reference and working groups within the following areas:

GEOGROUP

Dr. Sten G A Bergman

Stocksund

Dr. Otto Brotzen

Geological Survey of

Sweden

Professor Y Guscafsson

Royal Institute of

Technology

Dr. Rudolf Hiltscher

Saltsjö-Boo

Professor Ingvar Janelid

Royal Institute of

Dr. U Lindblom

Technology

Professor Roland Pusch

Hagconsult

Lulea Institute of

Jan Rennerfelt, Lic.Eng.

Technology

Professor Ove Stephansson

Orrje \& Co. AB

Lulea Institute of

Technology

REFERENCE GROUP FOR CORROSION

Roger Carlsson, Lic.Eng.

Swedish Silicate Research

Institute

Chief Engineer Thomas Eckered

Nuclear Power Inspecto-

rate 
Lars Ekbom, Lic.Eng.

Göran Eklund, D.Eng.

Professor Ingemar Grenthe

Dr. Rolf Hallberg

Sture Henriksson, M.A.

Professor Einar Mattsson

Professor Nils-Gösta Vannerberg

Professor Gösta Wranglén

CHEMISTRY GROUP

Bert Allard, D.Eng.

Dr. Otto Brotzen

Professor Ingemar Grenthe

Kåre Hannerz, Lic.Eng. Arvid Jacobsson, Ph.D.

Professor Ivars Neretnieks

Professor Roland Pusch

CROUP FOR DESIGN STUDIES

Alf Engelbrektsson, M.Eng.

Göran Fröman, M.Eng.

Bo Gustafsson

Bertil Mandah1
Swedish Corrosion

Institute

Institute for Metals

Research

Royal Institute of

Tecinology

University of Stockholm

$\mathrm{AB}$ Atomenergi

Corrosion Research

Institute

Chalmers University of

Technology

Royal Institute of

Technology

Chaimers Universicy of

Technology

Geological Survey of

Sweden

Royal Institute of

Technology

ASEA-ATOM

Luleå Institute of

Technology

Royal Institute of

Technology

Luleå Institute of

Technology

Swedish Hydraulic

Engineering Company, Ltd. Swedish Hydraulic

Engineering Company, Ltd. SKBF

OKG

GROUP FOR LEACHING STUDIES

Dr. Hilbert Christenssen

Lennart Deve11, M.Eng.

$\mathrm{AB}$ Acomenergi

$\mathrm{AB}$ Atomenergi

Roy Forsyth, Ph.D.

$\mathrm{AB}$ Acomenergi

Ragnar Geh1in, M.Eng.

Kåre Hannerz, Lic. Eng.

$\mathrm{AB}$ Atomenergi

ASEA-ATOM 
GROUP FOR SAFETY ANALYSIS

Peter Behrenz, graduate physicist ASEA-ATOM

Ronny Bergman, Ph.D.

Lennart Deve11, M.Eng.

Berti1 Grundfe1t, M.Eng.

Kåre Hannerz, Lic. Eng.

Professor Ivars Neretnieks

Curt Stenquist

AB Atomenergi

AB Atomenergi

Kemakta Konsult AB

ASEA-ATOM

Royal Institute of

Technology

AB Atomenergi 
Abatract - . . . . . - . . . . . . . . . . . . . . C-3

C-1. Basic Data Requirements . . . . . . . . . . . . . . C-3

C-2. Stripp Mine Test Site . . . . . . . . . . . . . . - c-4

C-3. Hydrologic Data and Radionuclide Transport . . . . . . . . C-4

C-4. Single Borehole Tests and Representative

Elementary Volume . . . . . . . . . . . . . . . C-B

C-5. Intermediate-Scale Bydraulic Conductivity

Tests (SAC-G2) . . . . . . . . . . . . . . . . . C-13

C-6. Dirsctional Permeabilities . . . . . . . . . . . . . c-14

C-7. Large-scale Hydraulic conductivity Measurenents . . . . . . C-14

C-8. Hydraulic Properties of Fractures (SnC-17) - - . . . . . . C-18

C-9. Groundwater Geochemistry and Isotope Bydrology . * . . . . C-19

C-9.1 Sources and Analysis . . . . . . . . . . . . . C-19

C-9.2 The Chemical characteristics of the Groundwaters • . - - c-20

C-9.3 Geochemical Processes and the Geochemical

Evolution of Groundwater . . . . . . . . . . . . c-23

C-9.4 Dissolved Gases . . . . . . . . . . . . . . . c-24

C-9.5 Groundwater Redox Potential . . . . . . . . . . . c-24

C-9.6 Stable Isotope Ratics . . . . . . . . . . . . . C-25

C-9.7 Radioactive Dating . . . . . . . . . . . . . - c-27

C-10. Some General Conclusions . - . - . . - . - . - . - c-29

C-11. References . . . . . . . . . . . . . . . . . . c-32 


$$
c-2
$$




\title{
APPEIDIX C
}

HYDROLOGICAL STUDIES OF A POTELIIAL WATE RAPOSITORY II GRANITS:

\section{A SORVEY OF THB STRIPA PEOJECT}

\begin{abstract}
ABSMRAT
In July 1977 the Swedish State Pover Board and the U.S. Departwent of Energy, through their contractors, the Swedish Huclear Fuel Supply Company (SKBF) and the Lawrence Eerkeley Laboratory (LBL), Joined in a feabibllity study of storage of radioactive wastes in mined granite caverns. A progran was developed for determining physical paraneters and hydrology of rock at an abandoned iron ore mine near stripa, about $200 \mathrm{kn}$ northwest of stockholn. The mine's tunnels form a labyrinthine maze covering approxinately $250 \mathrm{~km}$ at 15 levels, part of these through a massive body of granite at about 340 below the surface. During the last three years a beries of testa has been carried out addressing the problem of predicting the thermaechanical behavior of a heterogeneous and discontinuous granite mass and predicting the wovesent of groundwater through such granite. The findings are being published by SKBF and LBL in a serles of joint reports. They are referred to by the designation SAC-01, SAC-02, etc., and are listed at the end of this appendix. These reports provide the basis of this oumary of the hydrological findings up to March 1980. General conclusions drawn by the present author are sumarized in Section 10.
\end{abstract}

\section{C-1. BASIC DATA REQUIREMTENIS}

Storage in wined underground repositories is presently considered as the least objectionable way of dispoing of radioactive waste. Crystaline rocks-such as granite-are believed to have properties suitable for the extremely long storage tines required. Radionuclides from the atored waste may dissolve in the groundwater and migrate with it through the fracture systen penetrating the rock wass. In order to estimate the tire for wuch 
radionuclides to reach water bodies used by wan, it is essential to know the anount, velocity, and other properties of the groundrater. The anount and velocity depend on the fracture system and 1ts behavior during the thermal cycle associated with the radioactive decay.

At the stripa mine the suitability of the granite rock for atoring radioactive waste is studied by four different methods:

1. Mechanical characterization, including wonitoring the responses to thermal loading of jointed rock in situ, and mechanical tests on cores from $25 \mathrm{~mm}$ to $1 \mathrm{~m}$ in diameter.

2. Geological chara tertaation, including detailed surface mapping. subsurface mapping, and core mapping.

3. Geophysical characterization, using a variety of borehole techniques (TV-scanning, gamma logging, neutron logaing, sonic tests, measurenent of electrical resiscivity, etc.).

4. Bydrologic characterization, through injection tests, punp tests, water pressure measurements, and controlled inflow tests to tunnels.

In this report we cover only hydrologic characterization. First, though, we describe the stripa mine test site.

\section{C-2. STRIPA HINE TEST STTE}

Iron ore has been produced from the stripa mine since 1485. Tt was closed in 1976 by its latest amer, Stalibergsbolagen. The mine, which is about $200 \mathrm{~km}$ northwest of stockholn, sweden (rig. C-1), drew its ore from hematite-rich zones in leptite, a quartzofeldspathic metamorphic rock of the granulite facies. This leptite was Intruded by a medium-grained granite in which a considerable part of the mine accessways are located (FIgs. C-2 and c-3). It 1 s from such arifts at the $360-\mathrm{m}$ level of the mine that arifts were excavated for the in situ heater tests and other experiments at the $338-\mathrm{m}$ level (FIg. C-4).

\section{C-3. HYDROLOGIC DATA AND RADIONUCLIDE TRANSPORT}

Then dissolved nuclides are transported by groundwater they tend to sorb on rock surfaces along the fractures. This sorption can be measured and is given by the distribution factor $D$ (amount of radionuclide per kilogram of 

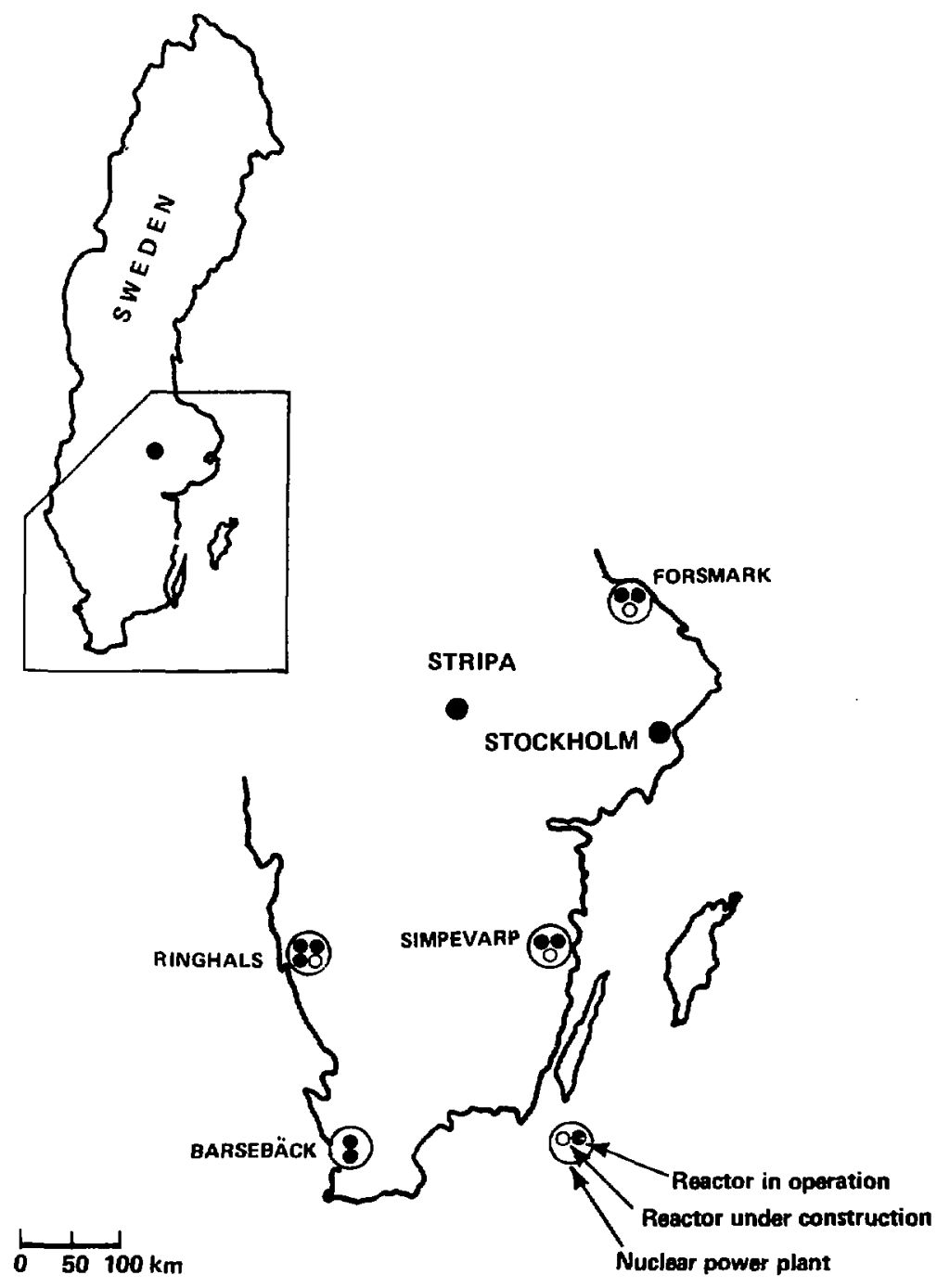

SCALE

FIG. C-1. Location of Stripa Hine. 


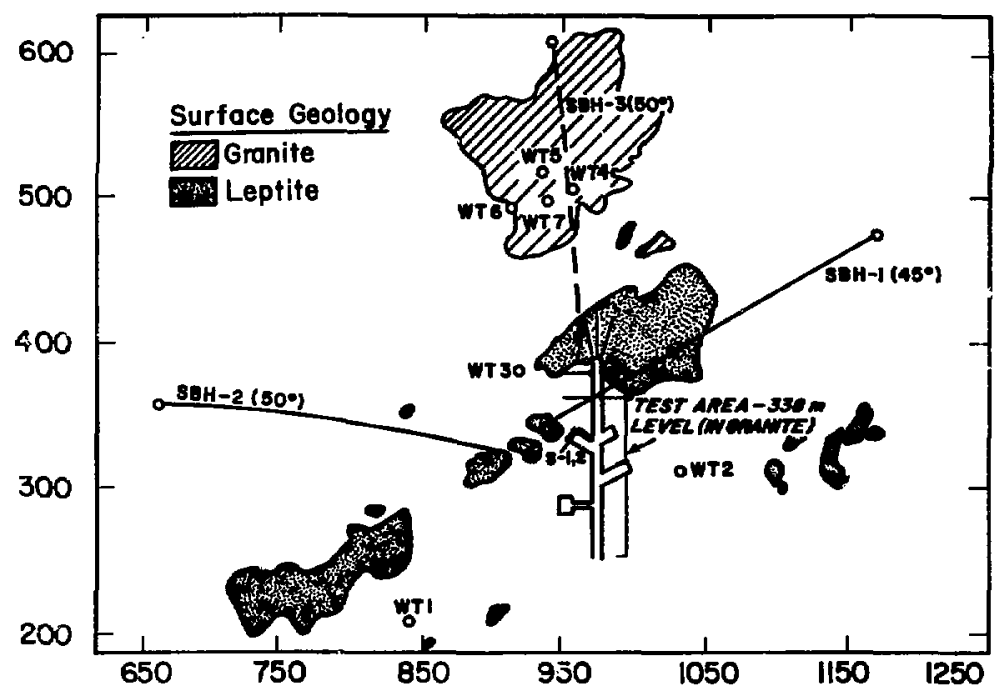

FIG. C-2. Relative locations of bedrock outcrops, surface boreholes (SBH), and test excavations (WT).

rock divided by amounts of radionuclide per cubic meter of water). D depends on the chemical properties of the radionuclide, of the rock, and of the groundwater. One effect of the sorption is that the radionuclide usually travels with a lower velocity, $v_{n}$, than the velocity of the groundwater, $v_{\text {aq' }}$ according to

$$
v_{n}=v_{a q}\left(1+D \cdot \frac{\varrho}{\varepsilon}\right)^{-1}
$$

where $\rho$ is the rock density $\left(\mathrm{kg} / \mathrm{n}^{3}\right)$ and $\varepsilon$ is the rock bulk porosity (volume of water in rock divided by total volune of rock).

The specific discharge of water, $\nabla_{d}$, is defined by

$$
\nabla_{\mathbf{d}}=Q / \mathbf{A}
$$




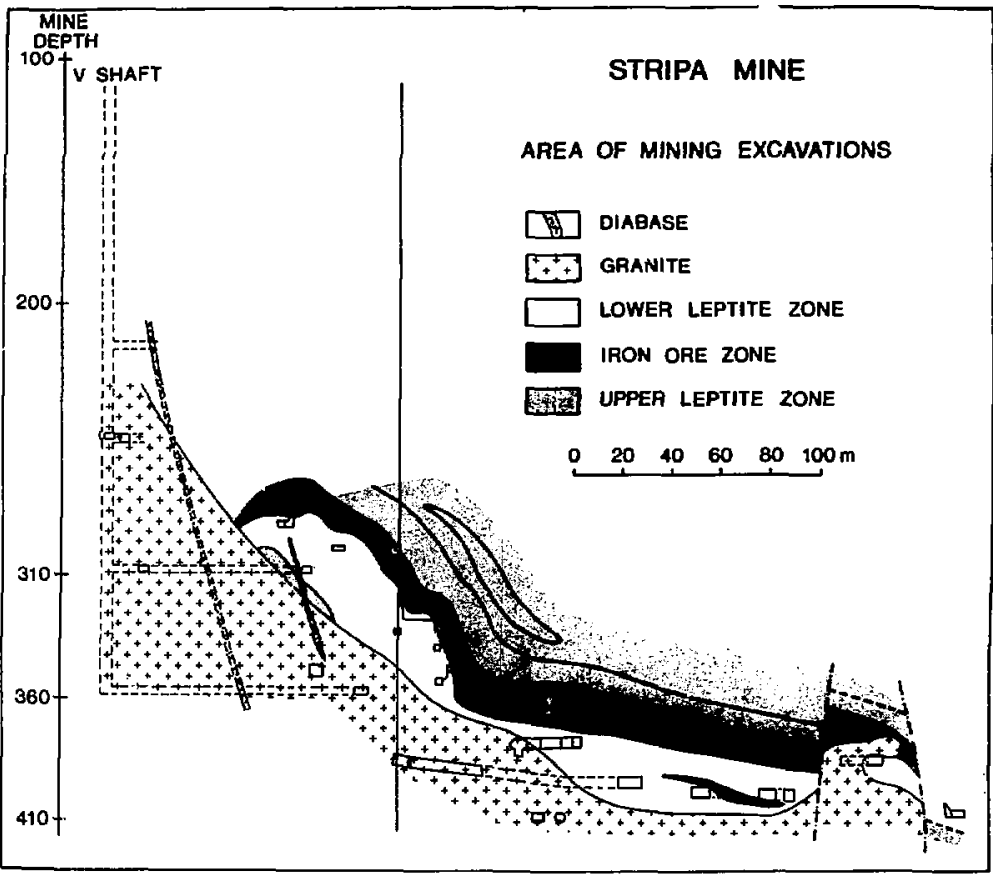

FIG. C-3. Vertical profile showing the subsurface geology in the area of the test excavations along cross section $\mathrm{A}-\mathrm{B}$ in Fig. C-1.

where $Q$ is the water flow $\left(a^{3} / 8\right)$ through the area $A\left(m^{2}\right)$. The water flow through a specific aite can be calculated frow Darcy's law,

$$
Q=K \cdot \mathbf{R} \cdot \mathbf{i},
$$

for the hydraulic conductivity $\mathrm{K}(\mathrm{m} / \mathrm{s})$ " and hydraulic gradient $i$ for "head",

\footnotetext{
"X is sonetined referred to as perneability. The (specific or intrinsic) permeability $k$, however, is defined as $k=k \cdot \mu /(p \cdot g)$, where $\mu$ is the kinetic viacosity, $\rho$ ia the density of the fluid (water), and $g$ is the gravitational conntant.
} 


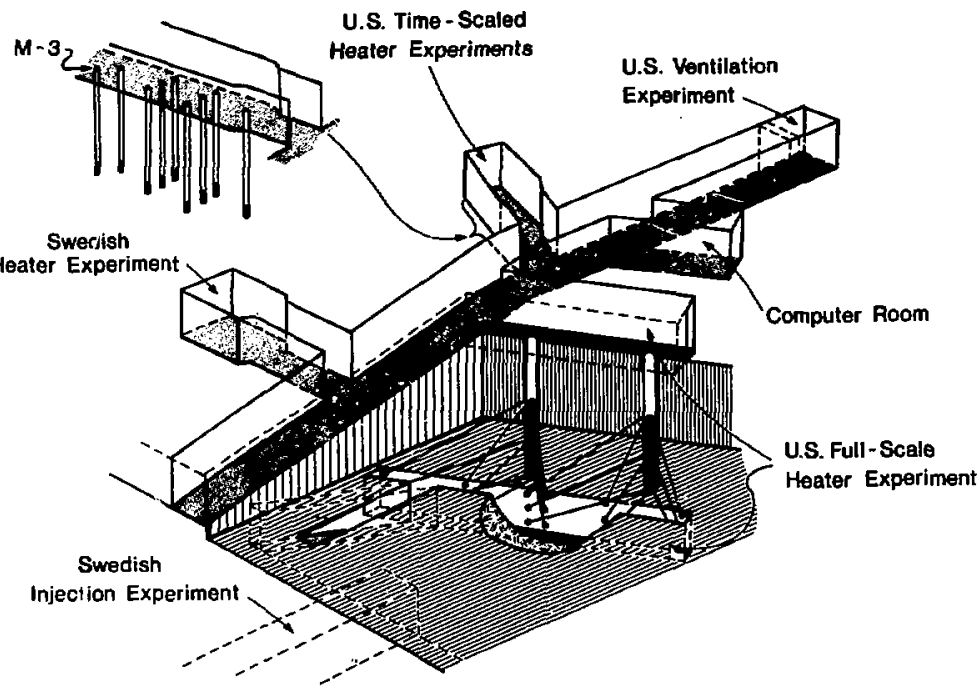

FIG. C-4. Dnderground excavations near the $330-\mathrm{m}$ level, showing the location of boreholes, inclujing $\mathbf{H - 3}$ (SAC-01, SAC-27).

1.e., drop in water preseure, $[\mathrm{m}]$, per horizontal distance, [m]). The 11near water velocity, in the rook $\nabla_{\mathrm{aq}}(\mathrm{m} / \mathrm{s})$, is

$$
\nabla_{\mathrm{aq}}=\mathrm{g} /(\varepsilon \cdot \mathrm{A})
$$

becauge water moves only in the rock fractures.

It is obvlous that in order to predict the radionuclide transport rate it Is essential to know the intrinsic parameters $D, K$, and $\varepsilon$. The Stripa project has focused on the determination of representacive values for $k$ and $\varepsilon$.

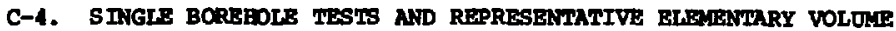

Darcy's equation le valid unly for a homogeneous isotroplc mediun. However, a granite repository is crisacrossed by fractures of different sizes and in different alrections, the larger of the fractures being filled with 
other minerale, so that each fracture or rock segnent is being characterized by 1 te own values of $K$ and $\varepsilon$. The main problem, therefore, becomes how to assign representative values for $K$ and $E$ assuning that a properly selected repository is free of larger crush-zones, where water flows freely. This problem may be illustrated by the following case.

The hydraulic conductivity has ieen measured in single holes (10-m deep, 76- $\mathrm{mm}$ in diameter) drilled in the floor at the 360-m level of the Stripa mine, see FIgs, C-4 and C-5 (ShC-02). Visual ingpection of the holes shows 5 to 10 fractures per meter. Some fractures are minide, filled with chlorite (a clay-like weathering product of granite), while fractures $<0.2$ wa could not be observed (TV Scanning). Double-packer tests" over fractures show that not all fractures are water-bearing.

The results of measurements of hydraulic conductivity (Table c-1) lead to some general conclusions, also verified in other experiments:

- The hydraulic conductivity varies strongly from hole to hole, even when the holes are close together (Fig. C-5).

- The average value of $R$ obtained by the double-packer test does not agree with the (integrated) value of the single-packer test over the same section. In general, the double-packer tests give a higher value of $\mathrm{X}$ (up to seven times!).

The hydraulic conductivity varies considerably along a borehole, covering several powers of 10 ovei distances as short as 10 meters (Fig. C-6). For borehole location, see Fig. C-2. Consequently, when a single measurement of $\mathrm{K}$ (or E) is made in an arbitrary volume of rock, there is no way of knowing, a priori, whether or not the neasured value is representative of a larger rock body contemplated as a waste repository. As the volume of the fractured rock sample increases from zero, the average value will oscillate as either fractured rock or solid rock 18 added to the sample (Fig. C-7). When the volume of rock becomes so large that $R$ or $\varepsilon$ is no longer sensitive to the effects of Individual fractures, the oscillations will subside. An average value can then be assigned to that volume of rock, which is called the representative elementary volume (REV) (Fig. C-7, V3). Theoretically, volunes

\footnotetext{
"In single-packer tests, the lower part of a borehole is sealed off by a rubber packing at the upper end, and the hydraulic propertles (pressure and water flow as a function of time) are then neasured below this packer. In the double-packer test the hydraulic properties are neasured between two packers at a certain distance between each other.
} 


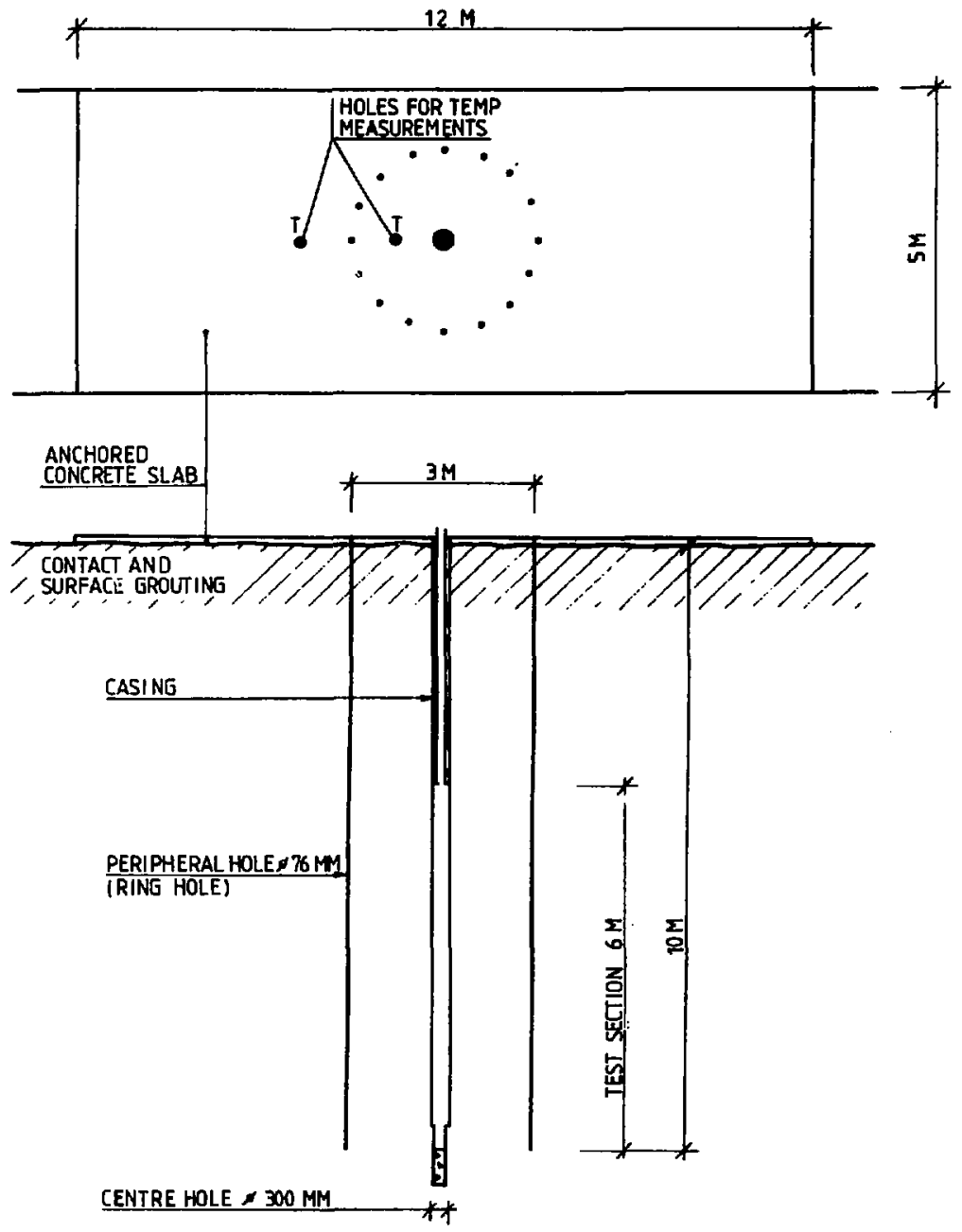

FIG. C-5. Layout of each teat place. 


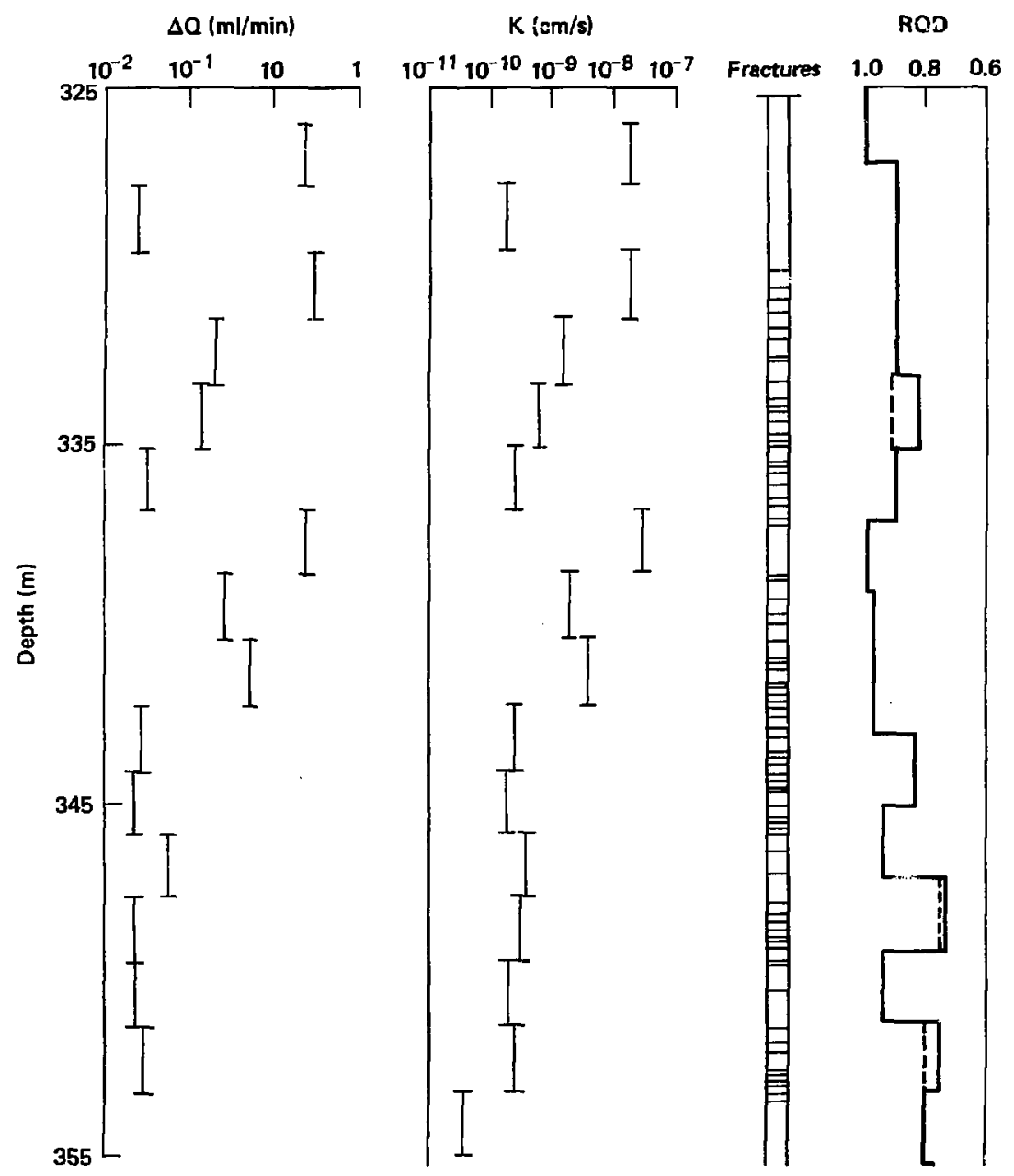

FIG. C-6. Injection test results and fracture data for the interval 325 to 355 in in SBH-1. 
MBIs C-1. Fydranlic conductivity, $\mathrm{K}$, in the lower 6-m section of some peripheral boreholes $\left(10^{-9} \mathrm{a} / \mathrm{a}\right)$.

\begin{tabular}{ccc}
$\begin{array}{c}\text { Borehole } \\
\text { number }\end{array}$ & $\begin{array}{c}\text { Double packer } \\
\text { test }\end{array}$ & $\begin{array}{c}\text { single packer } \\
\text { test }\end{array}$ \\
\hline 1 & 3.1 & 2.0 \\
4 & 1.3 & 0.20 \\
14 & 0.87 & 0.34 \\
\hline
\end{tabular}

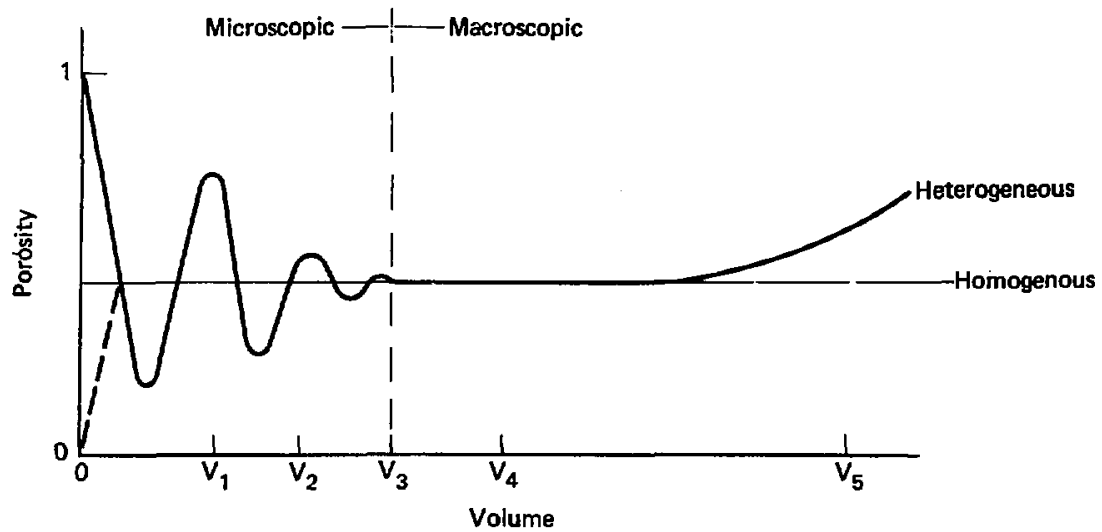

FIG. C-7. Microscoplc and macroscopic domains and the representative elementary volume $v_{3}$ (from Freeze and Cherry, 1979).

of rock the size of the REV can be treated as porous media for regionai analyses of groundwater flow.

In fractured rocks, where the discontinuities thenselves nay occupy areas on the order of $10^{2} \mathrm{~m}^{2}$, it is reasonable to expect $\mathrm{REVg}$, if they exist, to be on the order of $10^{4}$ or $10^{5} \mathrm{~m}^{3}$. The large-ucale permeability experiment at Stripa will permit a meaburement of the average permeability of $10^{5}$ to $10^{6} \mathrm{~m}^{3}$ of rock. There is no asaurance that this volume will be as large as the Ru, however, the experiment, taken along with other 


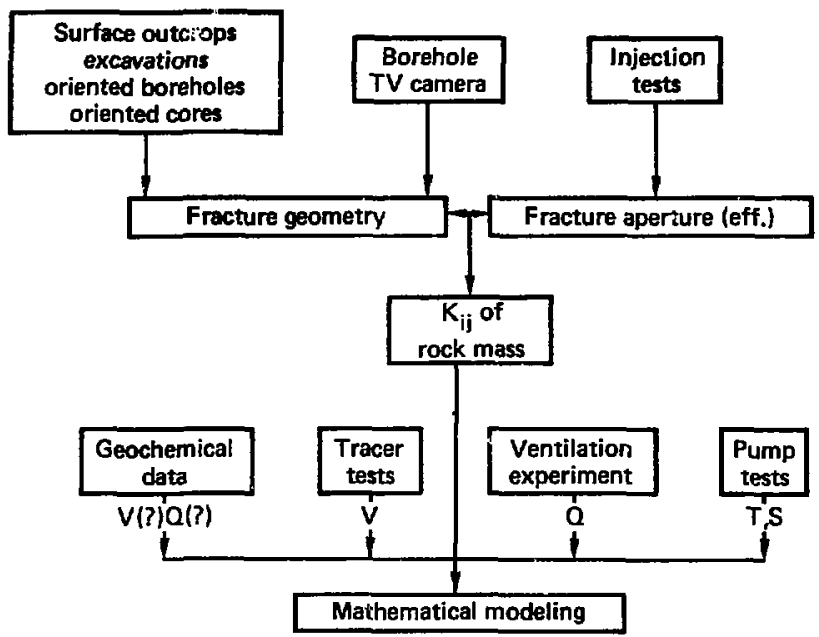

FIG. C-8. Block diagram of ateps in calculating directional permeabilities from fracture data.

amall-scale testa performed at the same site, should provide an indication of the existence and size of the REV.

The overall hydrological studies at Stripa are sumarized in Fig. C-8.

\section{C-5. INTERMEDIATE-SCAIB HYDRAULIC CONDUCTIVITY TESTS (SAC-02)}

In order to obtain reasonable flows in the experinental setup of Fig. C-5, pressure had to be applied to the peripheral holes. The effect of pressure on the mydraulic conductivity was therefore tested in a deparate experiment. Values of $K\left(\right.$ in $\left.10^{-9} \mathrm{~m} / \mathrm{s}\right)$ obtained were 0.88 (10) $\mathrm{kPa}$ overpressure) and 0.96 (300 kPa overpressure) at one test hole, and 0.51 (300 kPa overpressure) and 0.55 (900 kPa overpressure) at another test hole. Thus, a threefold pressure increase obviously has little influence on the value of $R$.

In the main test, the inflow of water into the central hole after pressure injection of water into the peripheral holes was converted to hydraulic conductivity, with the apecfal geonetry being taken into account. 
The rock was heated by circulating warm water in a closed systed. The constant overpressures at the peripheral holes were 100 and $500 \mathrm{kPa}$. For $10^{\circ} \mathrm{C}$, $\mathrm{R}$ was calculated at $4 \times 10^{-11} \mathrm{~m} / \mathrm{s}$, while for $36^{\circ} \mathrm{C}$ the value aropged to $2 \times 10^{-11} \mathrm{~m} / \mathrm{s}$. These values of $\mathrm{K}$ are lower by a factor of about 100 than the values obtained in single-testing the peripheral holes (Section 4) 1

The porosity of the rock was $1.3 \times 10^{-4}(0.0138)$ calculated from measurements of flow of a fluorescent dye from the peripheral holes into the central hole.

\section{C-6. DIRECTICNAL PERMEABILITIES}

If the fractures are assumed to consist of two-dimensional infinite planes with preferential orientation in the rock, it should, in principle, be possible to calculate the hydraulic conductivity and porosity from borehole measurements of fracture widths, spacings, and ortentation. The program to assess the directional permeability addresses this question (Fig. C-8).

Fracture orientations, spacings, and continuity have been obtained by mapping the fractures in surface outcrops and in the walls and the floorg of the subsurface excavations. Arother source of data is a group of three slanted boreholes drilled from the surface (Fig. C-2) to the 340-m test level. These holes are logged with TV cameras and double-packer tests. Data are obtained every $2 \mathrm{~m}$ (every $0.3 \mathrm{~m}$ for interesting fractures). Figures $\mathrm{S}-6$ and c-9 present some experimental data. The irregular hydrostatic pressure below the $200-m$ level shows the effect of long-term drainage from the mined caverns. The ROD (Rock Quality Designation) indicates the degree of fracturing.

It will probably be a long time before final results from these studies can be preserted.

\section{C-7. IARGE-SCAIE AYDRAUI IC CONDUCMIVITY MRASUREMINTS}

A 33-m section of a tunnel with a $30-\mathrm{m}^{2}$ cross section has been sealed off, so that the volume, humidity, and temperature of air entering and leaving the tunnel can be monitored. Also, 15 holes, 30-40 m long, have been driven 


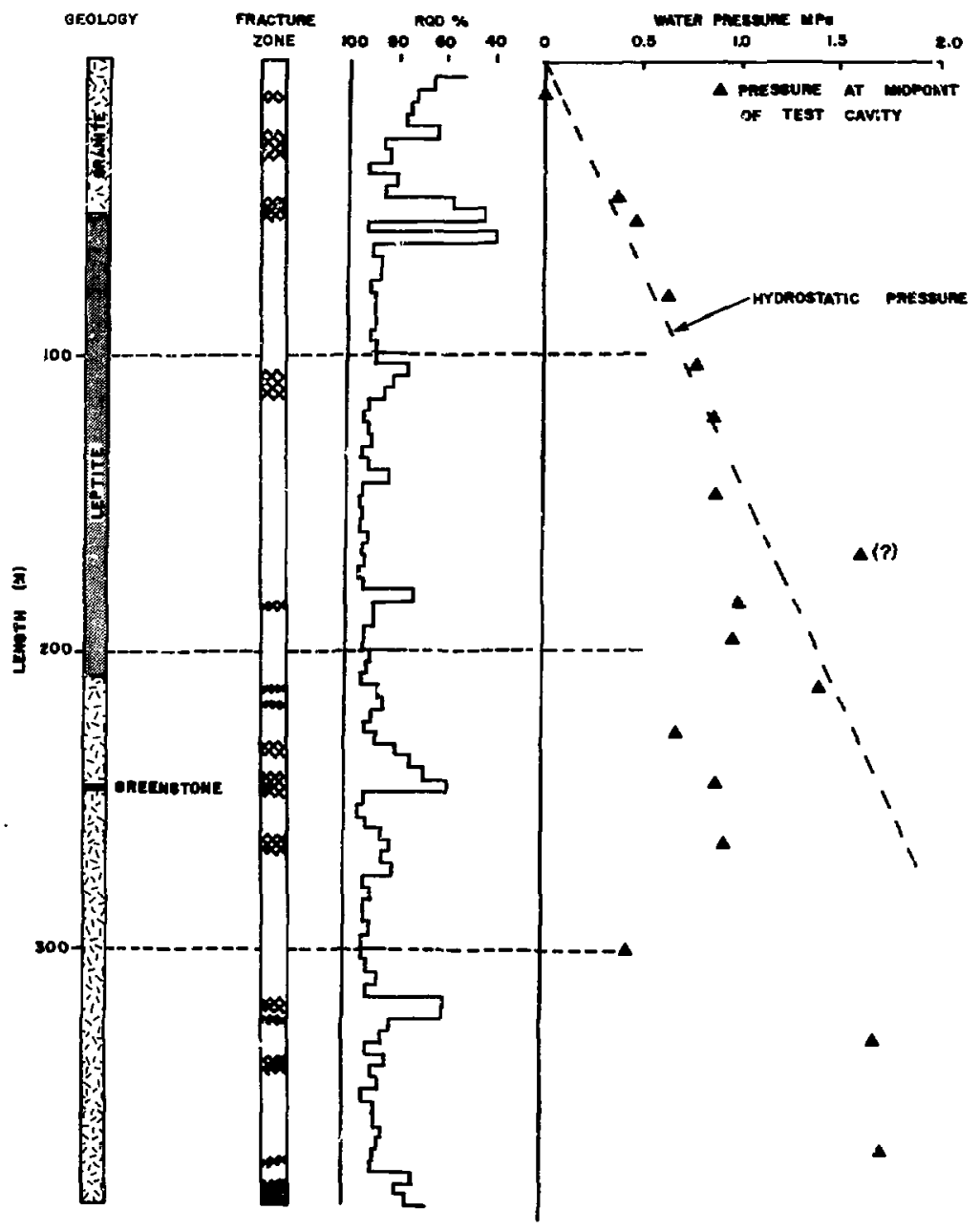

PIG. C-9. Results of fracture anō pressure measurements in SBH-1. 
Into the tunnel wils. See FIg. C-10. By measuring the anount of water vapor being removed by the ventilation systen, a direct neasure of the volume of water seeping in can be obtained. Furthermore, knowledge of the groundwater pressure gradient near the tunnel walls allows calculation of the overall hydraulic conductivity.

The pressure gradient in the rock wals 18 being neasured in the radial holes. Pigure $C-11$ shows that a pressure of about 1 IPa is reached about 30 in from the wall. These unusually low pressures are a result of the drainage that has gone on for some years in the adjacent wine workings. The figure also illuatrates the existence of connections between the fractures, because

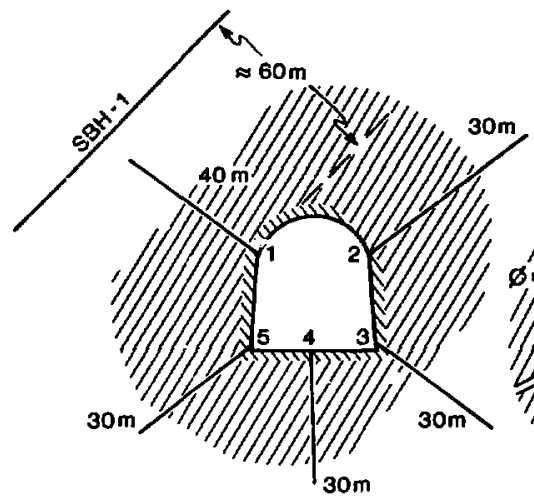

A
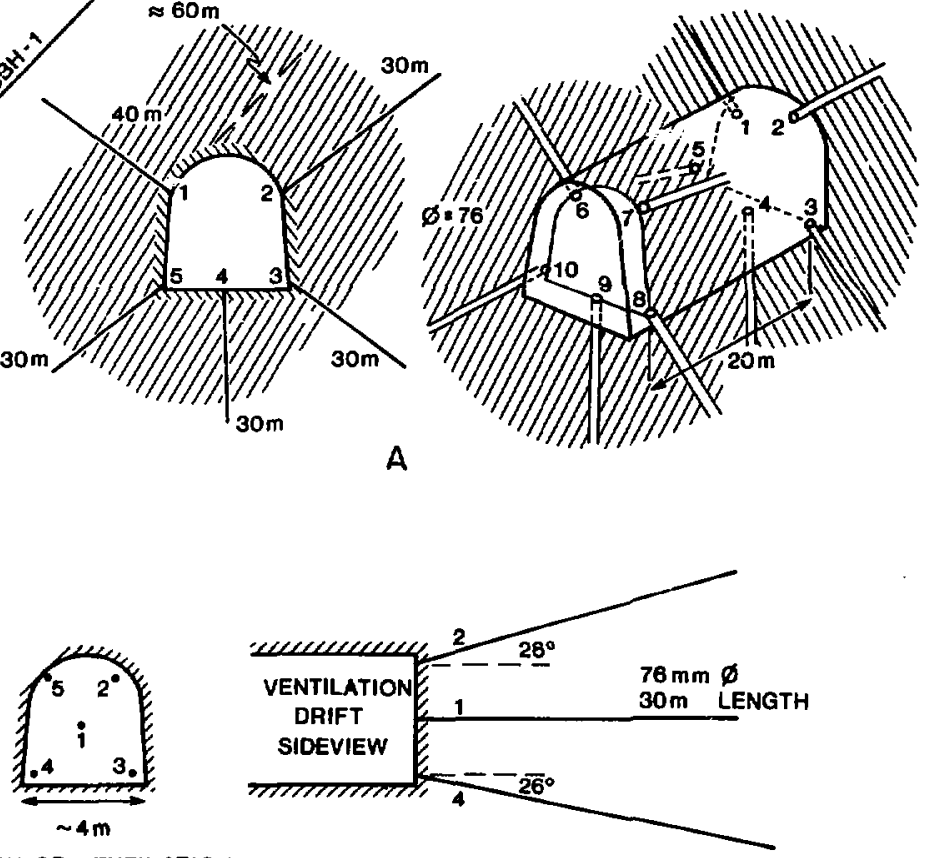

BACK OF VENTILATION DRIFT

7IG. C-10. Arrangement of subsurface boreholes in the tunnel section used for ventilation experimant at stripa. 


\section{Stress}

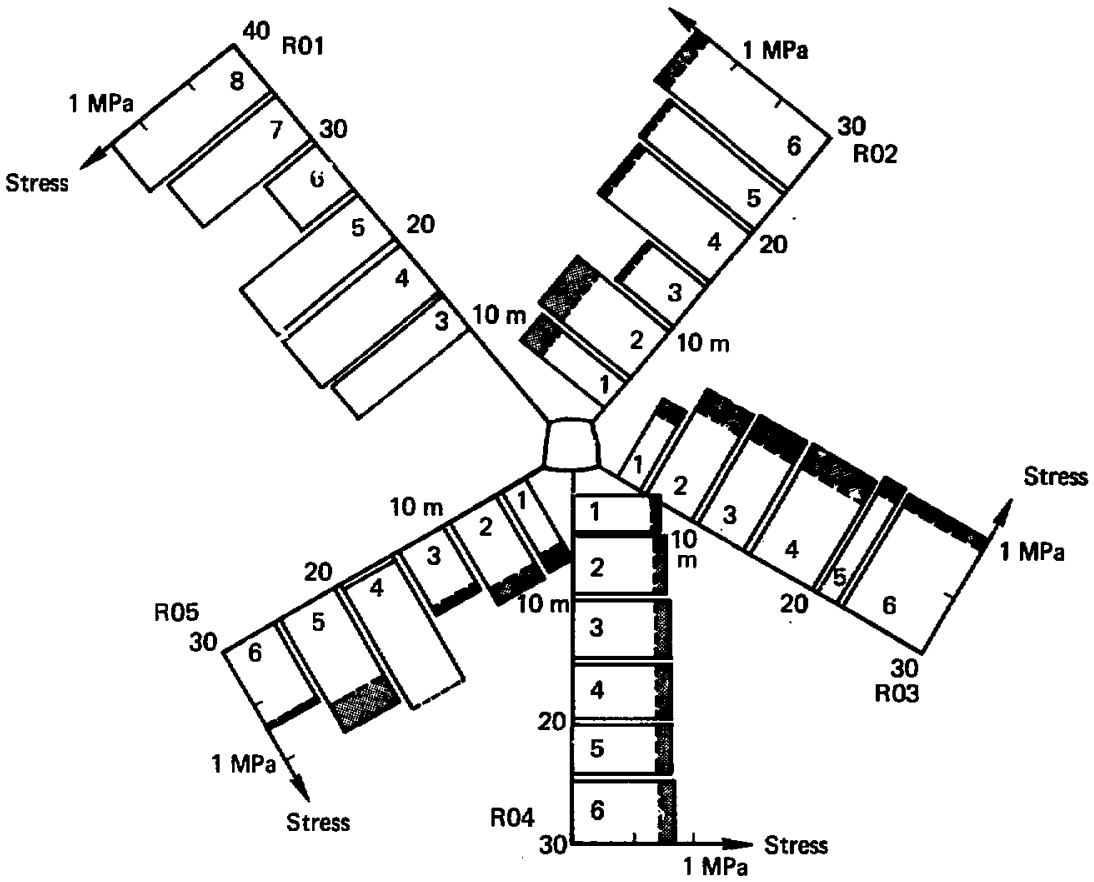

FIG. C-11. Pressure measurements in radial boreholes of ventilation drift at Stripa. Stlppled area shows pressure increases eight days after packing off ROl. $1 \mathrm{MPa}=145 \mathrm{psi}$.

the water pressures in all holes were found to increase where one bole (R01) was packed off. After all holes had been packed off, a narked Increase in drips and wet spots was observed in the tunnel.

To produce the current seepage rate of $50 \mathrm{ml} / \mathrm{ain}$ under the observed pressure gradients, the average hydraulic conductivity of the rock is about $10^{-11} \mathrm{~m} / \mathrm{s}$. This value refers to a rock mass of $10^{5}$ to $10^{6} \mathrm{~m}^{3}$, and compares favorably with the value presented in the previous paragraph for an "Intermediate-gized" rock nass of the order of $10^{2} \mathrm{~m}^{3}$. 
The hydraulic properties of a single fracture can be atudied in the laboratory. The advantage of laboratory study is that the experinental conditions can be carefully controlled, allowing testing of theories for the permeability of fractures. Figure C-12 shows schematically a test sample with a horizontal fracture. The water flow through this fracture as a function of applied load has been measured for test samples of various sizes (dianeter 0.1 to $1.0 \mathrm{n}$ ) and rock compositions (malnly granite), and with natural or artificially made fractures. Increasing the load (presgure firom 0.1 to 30 MPa) tightens the fracture and reduces water flow, and thus hydraulic conductivity. The general conclusion of the tests is that the enall samples which are generally used for laboratory tests (about $0.15 \mathrm{~m}$ in dianeter), yield permeabilities that are too low as coipared to permeabilities obtained in situ. It is therefore necessary to determine optimum specimen size before reliable results on flow in fractures under stress can be obtained.

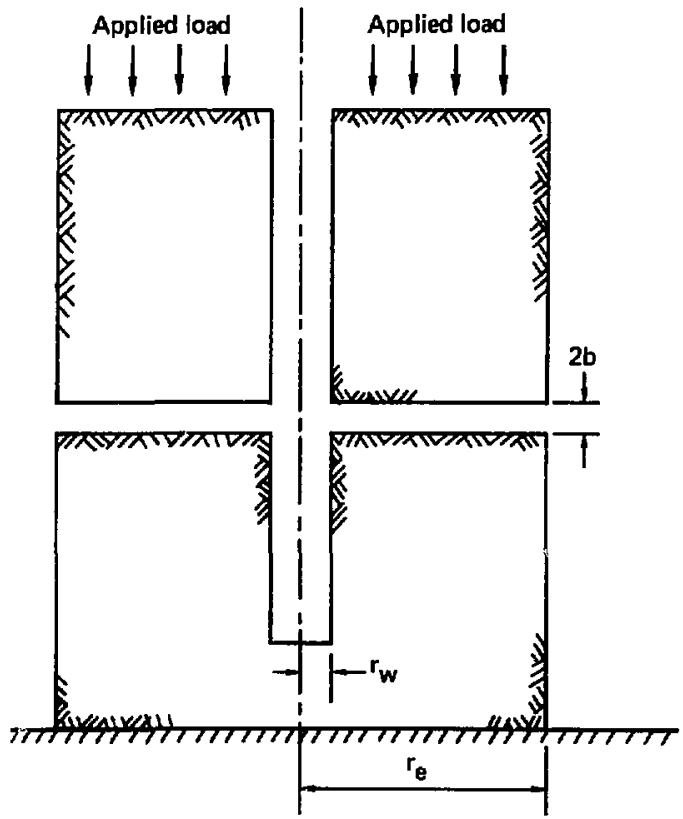

FIG. C-12. Radial flow model for laboratory experiments on a horizontal fracture. 


\section{C-9.1 SOURCES AND ANALYSIS}

Groundwaters have been extensively analyzed at stripa in order to provide an Independent approach to the problen of overall hydraulic conductivity of the rock. An assessment of fracture hydrology requires information about composition, origin, and age of groundwaters within the rock. The groundwater age is defined as the average transport time of water from the surface, where it is In equilibrium with surface waters, to the neasuring point.

Water samples were obtained from 4 private wells and 12 boreholes entering at the surface. (See Figs. C-3 and C-13; sce boreholes, e.g., SBH1-3, are rather deep, going down to the 290-w level.) Saples were also obtained from two boreholes entering at the 340-n level and one rather deep borehole entering at the 410-m level and going fown to $890 \mathrm{~m}$. Samles were taken and analyzed in the laboratory for

a. conductivity

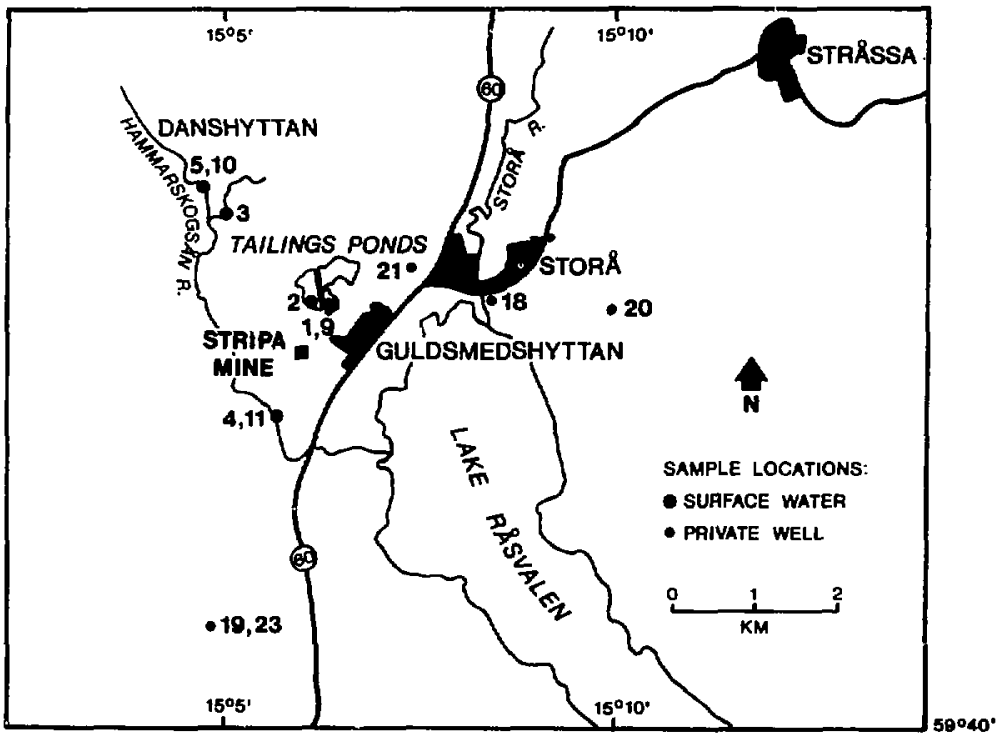

FIG. C-13. Locations of samples (surface water and private wells) in the vicinity of the stripa mine. The samples were subjected to chemical and isotopic analyses (see Fig. $\mathrm{C}-14$ ). 
b. temperature

c. $\mathbf{p H}$

d. dissolved $\mathrm{O}_{2}$

e. alkalinity

f. chenical composition $\left(\mathrm{Ca}, \mathrm{Hg}, \mathrm{Ma}, \mathrm{K}, \mathrm{Cl}, \mathrm{SO}_{4}, \mathrm{BCO}_{3}, \mathrm{SiO}_{2}\right.$,

Fe tot, $\mathrm{PO}_{4}, \mathrm{~m}_{3}$ and organic $\mathrm{C}$ ).

For the age determinations, analyses were al so nade for

g. dissolved noble gases (He, Me, Ar, Kr, Ke)

h. stable isotope ratios $\left({ }^{2} \mathrm{~B} /{ }^{1} \mathrm{~B},{ }^{18} \mathrm{o} /{ }^{16} \mathrm{o},{ }^{13} \mathrm{c} /{ }^{12} \mathrm{c}\right)$

i. radioactive isotopes $\left({ }^{234} \mathrm{~J},{ }^{238} \mathrm{v}\right.$ and cecay products).

The water sources thenselveg were monitored at site for properties (a) through (e). Seven laboratoriea participated in the large analytical task. Great care was taken to ayoid contaminations and to obtain high sensitivity. The analytical procedures are briefly described in shc-12, where the regultb of about 150 samples are also collected.

The analytical data have provided important information on the geochemical evolution, origin, and age of stripa waters. However, due to difficulties of interpretation, the results sumarized below are still only tentative.

C-9.2 THE CHEMICAL CHARACTERISTICS OR THE GROUNDWATES

The surface waters sampled in the stripa area are very dilute, with total dissolved solids (TDS) of less than $35 \mathrm{mg} / 11 \mathrm{ter}$. On a molal basis, the dominant species are $\mathrm{Ca}\left(\simeq \mathrm{BCO}_{3}\right)>\mathrm{Cl} \simeq \mathrm{Na} \simeq \mathrm{SO}_{4}>\mathrm{SiO}_{2}\left(>\mathrm{BCO}_{3}\right)>\mathrm{K}>\mathrm{Fe}$. The $\mathrm{pH}$ is 6.5 to 6.8 , nitrate is about $0.5 \mathrm{ppm}$, dissolved organic carbon is high $(5 \mathrm{ppm})$, and the waters are unsaturated wth respect to calcite.

Shallow groundwaters (from less than $100 \mathrm{~m}$ ) obtained from private wells contain TDS of 120 to $325 \mathrm{mg} / 1$ ter. These groundwaters are dominantly calcium carbonate water with

$$
\mathrm{HCO}_{3}^{-}>\mathrm{CA}>\mathrm{Na} \simeq \mathrm{Hg} \simeq \mathrm{SIO}_{2}>\mathrm{Ee} \simeq \mathrm{K} \text {. }
$$

The $\mathrm{pH}$ is 6.8 to 7.9 , nitrate is very variable (0 to $2.5 \mathrm{pga}$ ), and organic rarbon concentrations are much lower than in aurface waters-generally about 0.6 to 0.8 ppin carbon. These shallow groundwaters are, with few exceptions, unsaturated with respect to calcite. 
Deeper groundwaters from the 330-m level, and from the upper part of the 410-m-level borehole, are sodium chloride-bicarbonate waters with TDs of about 200 to $230 \mathrm{mg} / 1$ tter, and molal concentrations decreasing in the order

$$
\mathrm{Na}>\mathrm{Cl}>\mathrm{HCO}_{3}>\mathrm{Ca}>\mathrm{SlO}_{2} \approx \mathrm{Hg}>\mathrm{K} \approx \mathrm{Fe} .
$$

The $\mathrm{pH}$ is 8.8 to 9.05, nitrate $1 \mathrm{~s} 0$ to $1.2 \mathrm{ppm}$, and organic carbon is low (0.6 ppm carbon). Calclte saturation is slightly exceeded.

The deepest samples from below $700 \mathrm{~m}$ (from the borehole at the 110-m level) have the highest TDS (375 to more than $510 \mathrm{mg} / 1 \mathrm{iter}$ ) and are sodium-calcium chloride groundwaters with

$$
\mathrm{Cl}>\mathrm{Na}>\mathrm{Ca}>\mathrm{HOO}_{3}>\mathrm{SO}_{4} \simeq \mathrm{S}_{1} \mathrm{O}_{4}>\mathrm{K}>\mathrm{Fe} \text {. }
$$

These waters have high $\mathrm{pH}(9.5$ to 9.8), low nitrate (<0.3 ppm), and low organic carbon content $(<0.8 \mathrm{ppm})$. Calcite saturation is exceeded in all samples.

Geochemical varlations in groundwaters from stripa are illustrated in Fig. C-14, where the change In same geochemlcal parameters with depth can be seen. Depths of samples are measured from the surface and are only approximate in most cases.

Table C-2 presents a comparison of the concentration ranges in chemical species found In groundwaters from the Stripa mine (excluding private wells), from granites and gneisses in Sweden, and from granite of the Bohemian Massif (SAC-12).

The differences in Table C-2 are important: much higher concentrations of $\mathrm{Na}, \mathrm{Cl}$, and $\mathrm{HCO}_{3}$, much hIgher $\mathrm{pH}$ values, but lower concentrations of $\mathrm{Mg}$, $\mathrm{SO}_{4}$, and $\mathrm{Fe}$ were encountered at stripa and other swedish sites than In the Bohemian Massif. The differences might be explained on the basis of

- Different atmospheric input; different geocherical conditions affecting groundwater in the unsaturated zone or in other rock-types before the groundwater enters granite.

- Mineralogical variation in granites.

- Control of geochemistry by fracture mineralogy which would be different for different granites. 

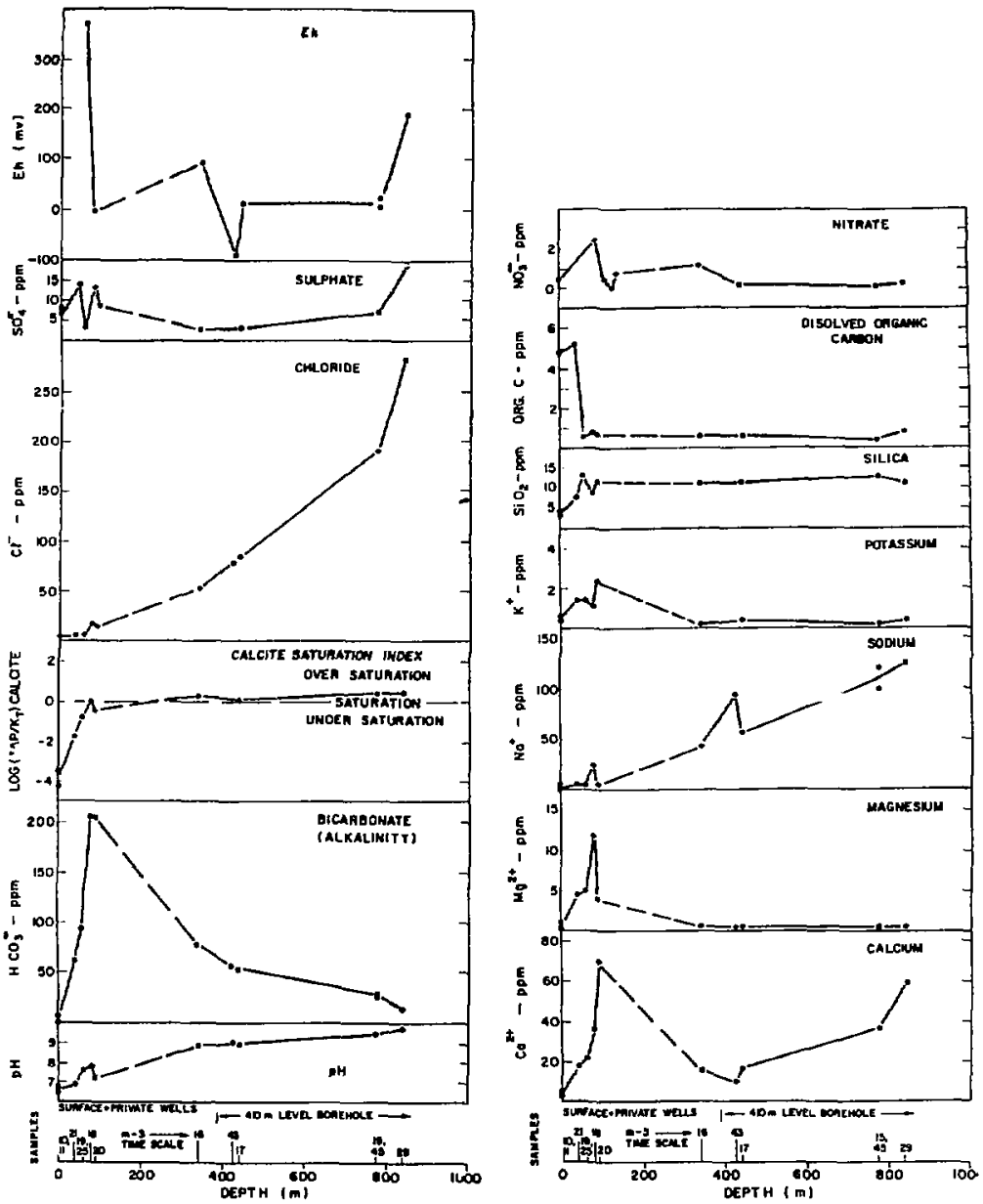

FIG. C-14. Geochemical variation of groundwaters with depth. See Fig. C-13 for location of sample nimbers. 
TABLE C-2. A comparison of the concentration ranges in chenical apecies in groundwaters from stripa, Swedlsh granltes, and gneisses from the Bohemian Massif (mg/11ter).

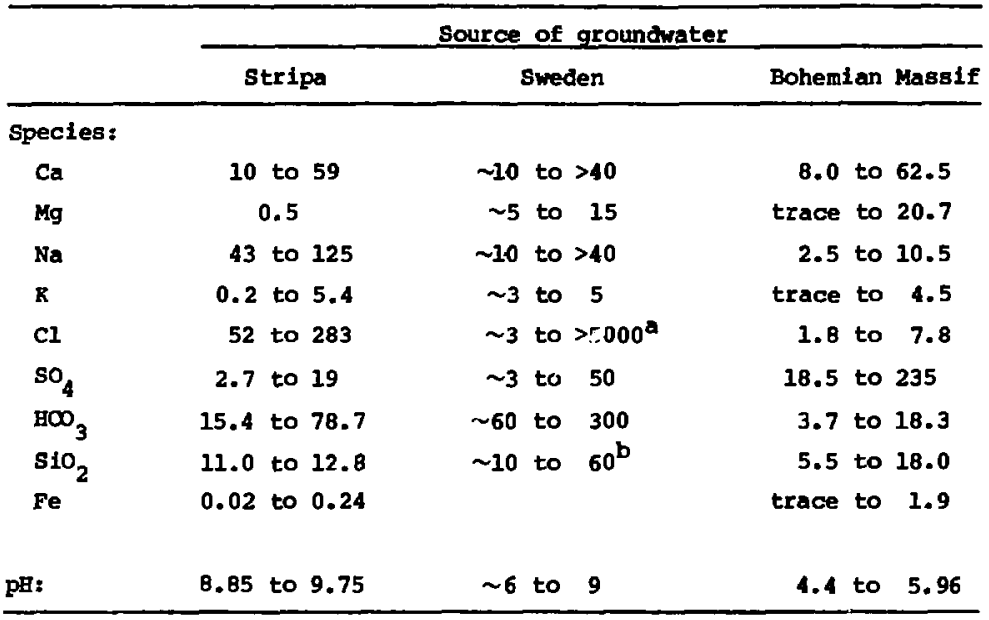

a Fossil seawater coriamination assumed.

bo actual analyses given but general quote of literature data.

- Different degrees of water-rock interaction due to different groundwater temperatures, different durations of water-rock contact, different physical fracture characteristics, etc.

- Presence of brines or seawater in the Stripa rocks.

C-9.3 GEOCHEMICAL PROCESSES AND THE GEOCEEMICAL EVOLDTION OF GROUNDNATER

Plota of groundwater couposition or mineral stability diagrans strongly indicate that all groundwaters sampled have followed similar evolutionary trends. Therefore, the stripa groundwaters are considered to evolve from original recharged waters to the presently observed groundwaters. Nater-rock Interaction is considered to be the mafor process causing geochenical change as waters flow in the subsurface. In view of the assumed increasing age of groundwaters with depth (see next paragraphs) deeper samples are thought to have undergone wore geochemical evolution than ghallow samples. The 
assumption 1s also made that modern shallow samples are sinilar to deeper samples as they existed at an earlier stage of evolution, or, to put it differently, that deeper sanples used to be like modern shailow aamles.

The increased concentration of $\mathrm{Ca}^{2+}$ and $\mathrm{Na}^{+}$, and decressed

concentration of $\mathrm{HCO}_{3}^{-}$and $\mathrm{Mg}^{2+}$ at the deepest level (FIg. C-14) is

explained as being due to mineralogic transformations and the mixing of normal groundwater with brine, perhaps residual seawater. The increasing pH is believed to be due to incongruent dissolution of silicates.

\section{C-9.4 DISSOLVED GASES}

The concentrations of dissolved gases give different kinds of information. Witrogen is added to the original water from air, but may also be formed through microblological denitrification (reduction of disaolved nitrate). Oxygen originates from the air but is consumed by oxidation processes, possibly also microbiologically (producing $\mathrm{CO}_{2}$ ). $\mathrm{CH}_{4}$ is produced through fermentation processes under anaeroblc conditions. In principle, it should be possible to calculate the redox potential of the groundwater from the $\mathrm{O}_{2}$ and $\mathrm{CH}_{4}$ concentrations, such calculations have falled, howeve::

The He ard Ar are of radiogentc origin and can be used for groundwater dating (see Section 9.7).

This leaves Ne, $\mathrm{Rr}$, and Xe as "undisturbed" gases. The solubility of these gases depends on the water temperature. For exanple, Xe dissolves to $18 \mathrm{ppb}$ (volume gas/volume water) at $1^{\circ} \mathrm{C}$, and to $7 \mathrm{ppb}$ at $30^{\circ} \mathrm{C}$. The concentrations of these gases in stripa groundwaters indicate a recharge temperature of $5-3^{\circ} \mathrm{C}$ at the $330-\mathrm{m}$ level, and $0-5^{\circ} \mathrm{C}$ for the bottom of the deep hole from the 410-m level. This result supports the assumption that the recharge occurred during the glacial period.

\section{C-9.5 GROUNDWALER REDOX POTEAYIAL}

Fh" was measured with a combination glass-calomel and platinum-disc electrode and values obtained were calibrated agalnst a "zobell solution" of

\footnotetext{
"Eh is the electrical potential of groundwater in relation to a hydrogen electrode ("water redox potentlal").
} 
known Eh. Heasurements were carried out in a flow cell at the sangle site. Readings were taken when stable values were obtained; these values are belleved to be correct to $\pm 5 \mathrm{mv}$. The following values were recorded: $+169 \mathrm{mv}$ around the 800-m level, $+122 \mathrm{mV}$ below 460-m, and $+92 \mathrm{mV}$ at the 360-m level. Attempts to use these enf values to calculate $\mathrm{pO}_{2}$ and $\mathrm{pCH}_{4}$ failed completely. The failure may be attributable to incorrectness, for unknom reasons, of the measured values of $\mathrm{Eh}$. It 16 posstble, for example, that samples were contaminated with air.

The previous paragraph is paraphrased from Ref. SAC-12, There are reasons to question these results. Measurenents by Prof. I. Grenthe (Royal Technical University, Stockholm) for very carefully collected stripa sables of $\mathrm{pH} 8.2$ yield $\mathrm{Eh}$ values from $-31 \mathrm{mV}$ to $-210 \mathrm{mV}$. These $10 \mathrm{w}$ redox potentlals can be ascribed to the presence of Re(II)-minerals in the rock and they agree well with theoretical calculations as well as foreign observations (B3).

\section{C-9.6 STABLE ISOTOPE RATIOS}

When molecules take part in physicochemical reactions (evaporation, precipitation, eic.), the relative concentrations of their isotopes may change slightly. Hater contains the hydrogen isotopes ${ }^{1}$ H (almost 100s) and ${ }^{2}$ g $(0.0158)$, and the oxygen 18otopes ${ }^{16} \mathrm{o}(99.768),{ }^{17} \mathrm{o}(0.048)$, and ${ }^{18} \mathrm{o}$ $(0.2048)$, leading to the existence of nolecules like ${ }^{1} \mathrm{~B}^{1} \mathrm{~B}^{16} \mathrm{O}\left(\sim 10^{6} \mathrm{PPm}\right)$, ${ }^{1} \mathrm{~B}^{1} \mathrm{H}^{18} \mathrm{O}(\sim 2000 \mathrm{PPm}),{ }^{1} \mathrm{H}^{2} \mathrm{~B}^{16} \mathrm{O}(\sim 320 \mathrm{ppm})$, etc. If the ratio of the hydrogen isotopes $\left({ }^{2} \gamma^{l} \mathrm{H}\right)$ is referred to as $\delta_{x}$ and $\delta_{B}$ in a given water sample and a standard, respectively, then the deviation of the sample from the standard is expressed as

$$
\delta\left({ }^{2} E\right)=1000\left(\delta_{x}-\delta_{B}\right) / \delta_{s}(\% / \infty)
$$

$\delta\left(^{18} 0\right)$ is defined in a sinilar way. The comon standard is skow (Standard Mean Oceanic water).

As a rule of thumb, the following values of deviation have been found (Dansgaard, 1964):

$$
\begin{aligned}
& \left.\delta f^{2} \mathrm{z}\right)=5.6 \mathrm{t}_{\mathrm{a}}-100(\% / \infty) \\
& \delta\left(^{18} 0\right)=0.7 t_{a}-13.6(\%),
\end{aligned}
$$


for water precipitated by rain or snow at an annual average temperature $t_{a}$ $\left({ }^{\circ} \mathrm{C}\right)$. Thus from mesourement of isotopic ratios, water precipitation temperatures, $t a$, may be estimated. Because water of the sane origin must have the same $t_{a}$, there $i_{s}$ a condon relation:

$$
\delta\left({ }^{2} \mathrm{H}\right)=8 \delta\left({ }^{18} 0\right)+10(\% / \infty)
$$

A plot of $\delta\left({ }^{2} \mathrm{H}\right)$ against $\delta\left({ }^{18} \mathrm{O}\right)$ yields a straight-1ine referred to as the global Meterological (or. Meteorlc) Mater Iine (Mr). In a given region (like central sweden), the precipitation follows such a line-the slope and intercepts vary slightly between different regions. Deviations from this line indicate secondary processes, such as rock-water interactions at elevated temperature.

In most hydrogeologic situations the ${ }^{18} \mathrm{O}$ and ${ }^{2} \mathrm{~B}$ contents of a groundwater reflect the recharge environment. For example, groundwaters formed immediately following the retreat of the last glaciation are lower in heavy isotopes than groundwater formed there today.

Figure C-15 presents the data from stripa. As a general rule, lower concentrations of heavy isotopes signify lower average annual terperatures at the recharge area. Therefore, the deep "saline" groundwaters, which have the lowest ${ }^{18} \mathrm{O}$ and ${ }^{2} \mathrm{~B}$ contents, must have recharged at lower average annual temperatures than the shallower groundwaters. This is confirmed by the rare gas analyses. One nust therefore conclude that the deep groundwaters have an origin different from that of the shallower ones.

This conclusion is further substantiated by comparing ${ }^{18} \mathrm{o}$ with the chloride concentrations as shown in Fig. C-16. Here, it is apparent that the deep groundwaters, especially those at the bottom of the 410-m hole, are distinctly different from the shallow groundwaters. In other words, the different fracture systems in the granite at stripa carry different types of water because the systems are isolated from each other.

One could argue that the lower ${ }^{18} 0$ isotope content in the deeper groundwaters is an indication of subglacial recharge. This conclusion is not supported by the ${ }^{13} \mathrm{C}$ analyoes; all waters from the mine levels have $\delta^{13} \mathrm{C}$ levels close to or below $-15^{\circ} / 00$. These levels indicate that blogenic sarbon if present in the diseolved organic carbon. The presence of biogenic carbon would signify that these groundwaters infiltrated through soll horizons, that 18, were generated during an interglacial period. 


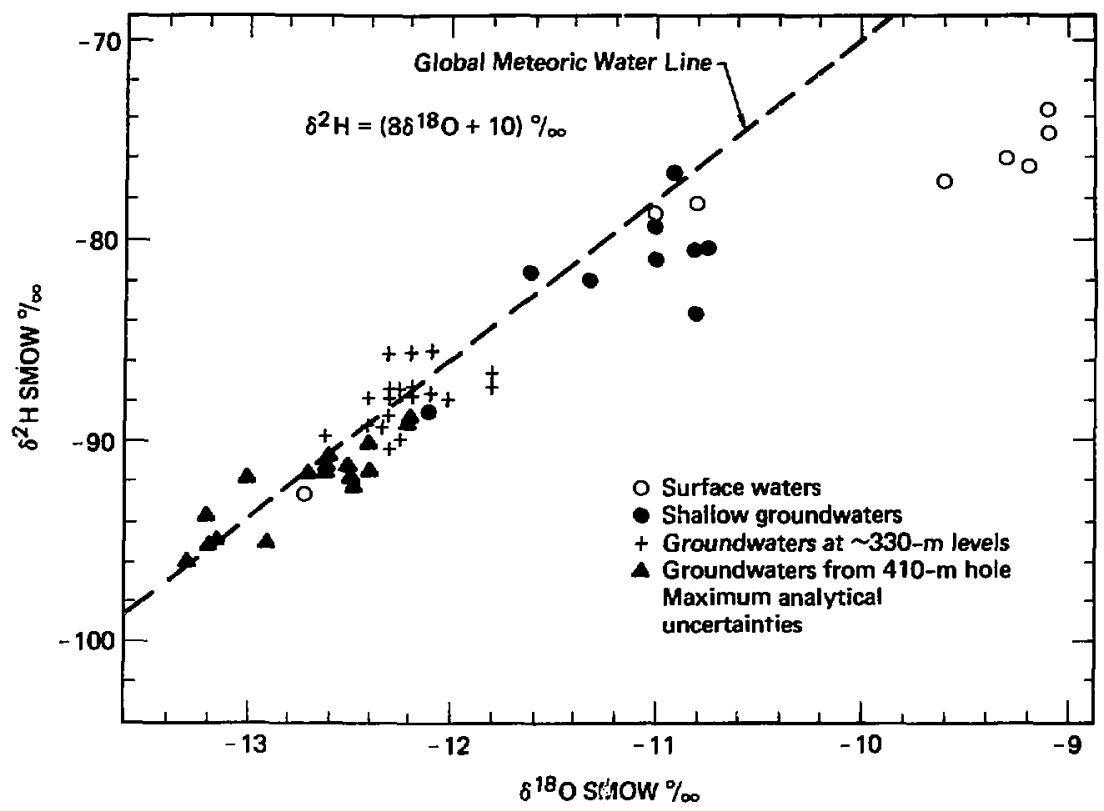

FIG. C-15. Compariaon of $\delta^{18} 0$ and $\delta^{2} \mathrm{H}$ values for Stripa groundwaters. The analyses are reported as $\delta \%$ values with reference to $5 N^{\circ}$. A $\delta^{18} 0$ of $-10 \% / 00$ signifies that the sample has $10 \%$ (per mil) less $18_{0}$ than the reference standard, which closely reflects average seawater.

\section{C-9.7 RADTOACTIVE DATING}

The most difficult and inconclugive part of the geochenical investigation was the attergt to date the groundwaters fron the different nine levels. Tritium level approaching $100 \mathrm{TO}^{\star}$ were found in all shallow groundwater ( $<100 \mathrm{~m})$ and, interestingly enough, even in the mine waters of the old workings. However, tritiun was not encountered (<0.5 TV) in any of the deep groundwaters from the granite, despite the above-mentioned drainage that has decreased water pressures below hydrostatic (see Fig. (-9). This lack of

\footnotetext{
11 20 1s equal to one tritiun aton $\left({ }^{3} \mathrm{~g}\right)$ per $10^{18}$ atoms of $1_{\mathrm{H}}$.
} 


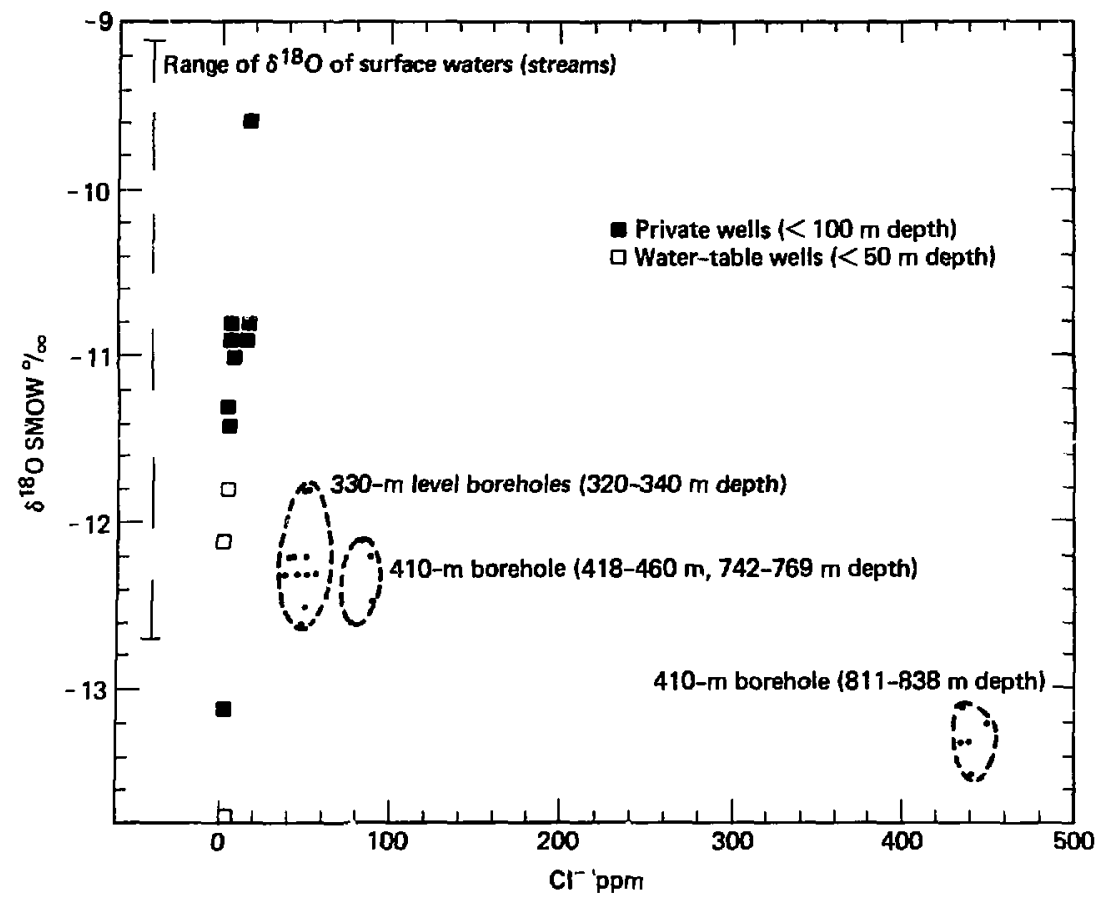

FIG. C-16. Comparison of chloride with $\delta^{18} 0$ values shows that the different fracture systems in the stripa granite carry differcnt types of water.

tritium indicates that the deep waters do not contain any aurface water component originating more than 30-40 years ago, 1.e.. when testing of hydrogen weapons began (producing large anounts of tritium).

Major probleas were encountered in attempting ${ }^{14} \mathrm{C}$ ag $\geqslant$ dating because of the very low content of disgolved inorganic carbon. It was necessary to treat 2000 to 3000 liters of water to obtain sufficient carbon for analysis. The results indicate that waters at the 330-m level, and probably also from che 410-m borehole, exceed 20000 years in age. Contamination of water samples from the 410-m borehole has prevented a more precise result.

Three different approaches to age dating based on the uranium decay serles were also investigated: (a) uranium activity ratios, (b) helium contents, and (c) radiun-radon relationships. The ${ }^{234} \mathrm{u} /{ }^{238} \mathrm{u}$ activity 
ratio in the groundwaters decreases from 10.4 at the 330-m level to about 6 at the top of the 410-m borehole and to almost 4 in the high "saline" waters at the bottom of this hole. This decay in activity ratio can be used to date waters (SAC-12). Although the method is still under devejopment and subject to some uncertainties, ages exceeding 100000 years are obtained for the groundwaters from the $410-\mathrm{m}$ borehole.

Somewhat lower ages were determined from the helium concentrations. The atmospheric concentration (volume helium/volume water) at $5^{\circ} \mathrm{C}$ is $4.9 \times 10^{-8}$, whereas the concentrations in the groundwaters at stripa are flve orders of magnitude higher, ranging from $0.3 \times 10^{-3}$ at tine $330 \mathrm{~m}$ level to $1.4 \times 10^{-3}$ in the 410-m borehole. From these data one can compice ages that range from tens oi thousands to hundreds of thousands of years.

If ${ }^{222} \mathrm{Ra}$ accumulates as a recoil product and is in equilibrium with ${ }^{226} \mathrm{Ra}$, then ${ }^{234} \mathrm{U}$ and ${ }^{222} \mathrm{Ra}$ activities will eventually reach equilibrium. Ages calculated by this model are 10000 to 35000 years for the different mine waters. An extension of this approach considers the ${ }^{226} \mathrm{Ra}$ concentrations in the rock minerals and the ${ }^{226} \mathrm{Ra}$ in the water. If equilibrium between the iwo exists, that is, if the recoil rate from the rock equals decay in the solution, then the waters must be at least 8000 years old (five halr-1ives of 226 Ra). There is evidence that this is the case, again supporting the earlier results that the waters presently found in the deep granite rock mass at stripa are indeed many tiousands of years old.

The preliminary results of the radioactive dating are sumarized in Fig. C-17. It is apparent that a careful investigation of the geochemistry and isotope hydrology provides an independent and powerful approach to the critical problem of elucidating thi degree of isolation that has developed in the Stripa groundwater bystems.

\section{C-10. SOME GENERAL CONCLUSIONS}

Studies at Stripa have demonstrated that for large granite rock bodies $\left(10^{2}-10^{6} \mathrm{~m}^{3}\right)$ consistent and $10 \mathrm{w}$ hydraulic conluctivities are found (of the order of $10^{-11} \mathrm{~m} / \mathrm{s}$ ), even when the rock body is highly fractured with several fractures per met:e, and double-packer tests over the fractures give conductivities varylng between $<10^{-11}$ and $10^{-8} \mathrm{~m} / \mathrm{s}$. Data frow these largebody studies compare favorably with measurements on granite tunnels $\left(\gg>10^{6} \mathrm{~m}^{3}\right)$ 


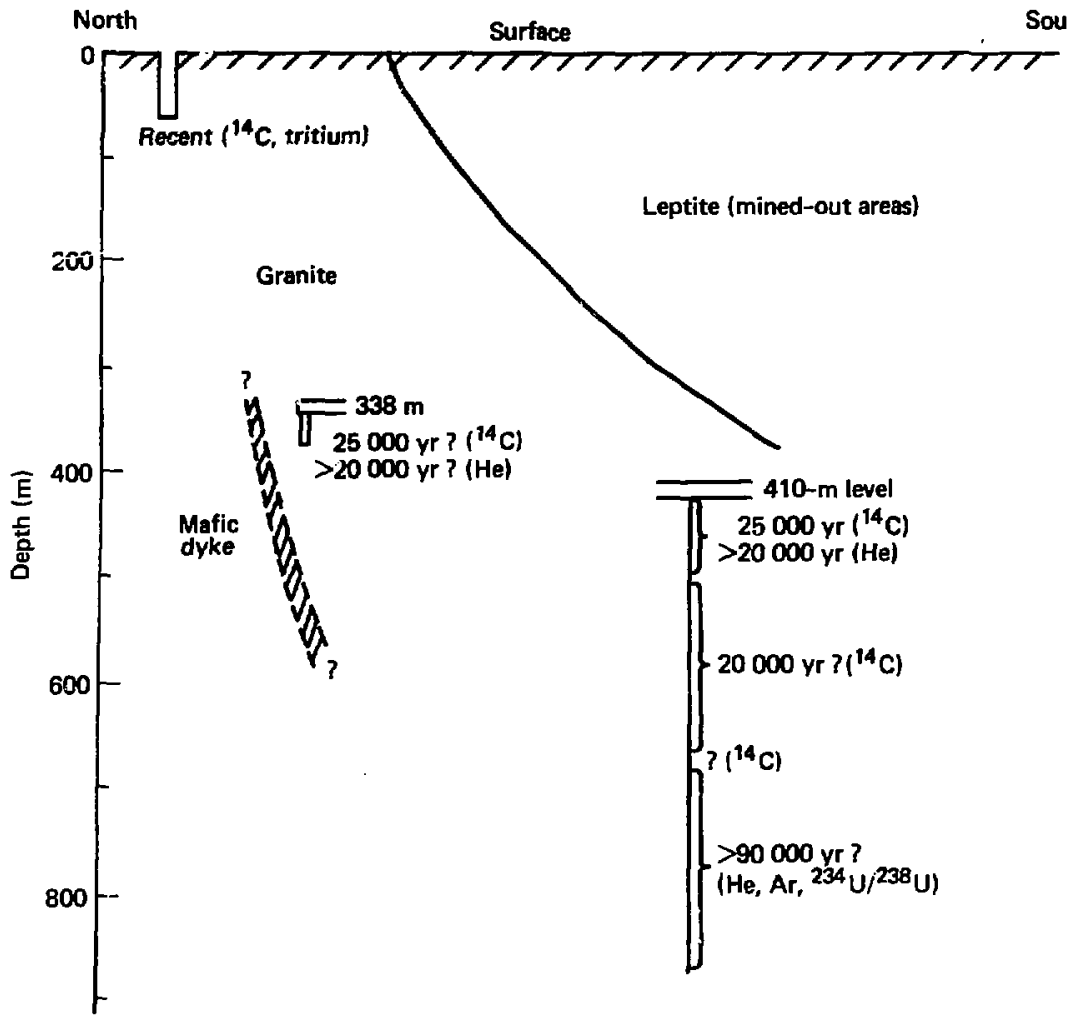

FIG. C-17. Preliminary results of 1sotope age dating of groundwater sanples. The method of dating is given in parentheses after the estimate. Question marks indicate uncertainty.

excavated 11 , sweden for military purposes, where in many cases overall conductivitles below $10^{-11} \mathrm{~m} / \mathrm{s}$ have been observed.

Introducing measured hydrological data $(x, 1, E)$ Into Daicy'a law yleldB volume: and velocities of water flos. An alternative technique for determination of flos velociti:* relies on meaturenent of the tine it has taken for the wter to nove from the burface down into the rock (the "water age"). Water age can be measured using "radloactive clocks." A numer of such clocks 
(0/He, $\mathrm{K} / \mathrm{Ar},{ }^{14} \mathrm{C}$, etc.) have been tested at stripa. Mlthough all indicated that the water is old, thousands of years or wore, none is conclusive. Ooviously, this is an extrewely difficult technique. Bowever, ita potential value as an independent technique for establishing water flow rates is so high that it is worthwhile trying to improve it. It should be noted, as an aditional complication, that water in different fractures way be of different age; age determinaions usually require large water saples and give therefore only average ages for the sangling voluae.

Unlike the chenical analyses, stable isotope $\left({ }^{2} \mathrm{~g}^{1} \mathrm{H},{ }^{18} \mathrm{o} /{ }^{16} \mathrm{o}\right)$ and gas measurements do not yield water ages directly, but relate water at different levels to each other. Therefore, these athods can serve only to Bupport hypotheses about age and flow of water.

Although the stripa mine project is only a geophysical and hydrological experiment, It is of some theoretical interest to consider the aine's suitability for final storage of highly radioactive waste.

There seens to be good geochenical evidence fo: the existence of two groundwater regions. In the lower region (below $600 \mathrm{~m}$, say) the water's composition Indicates that it contains fossil seawater aixed with glacial-welt water. About 10000 years ago this area was below the prtsent sea level. It is reasonable to assume that the ice melting and land uplift at that tine caused water to penetrate down to the lower region at Stripa. The gas analyais and stable isotope analysis indicate that this water was cold. The radioactive dating supports the inference that the low-Jevel water is very old, perhape wore than 10000 years. The ${ }^{13} \mathrm{C}$ data do not necessarily contradict this Inference.

The stagnant water would guarantee that radioactive wate stored at this level would not be transported to surface repositories (including shallow wells) before the end of a next ice age (assuned to begin 10-15 thousand years from now). At that future time the waste hazard would come from a few actinide isotopes ( ${ }^{237} \mathrm{~Np},{ }^{239} \mathrm{Pu}, 243_{\mathrm{Am}}$ ), which could be renoved from the wate before storage, thus eliminating the hazard alnost conletely. However, the existence of corrosive saline deep water night require the selection of container naterlals other then those now suggested. As a consequence of these findings, tise poesibility and consequences of establishing an "extra-deep" depository wetted by wainly stagnant saline groundwater should be considered as , an alternative to present plans for a depository at a depth of 500 . 


\section{A. glc reports}

These reports are the results of the Swedish-nerican cooperative research program. The progran has been sponsored by the swedish Nuclear Power Utllities through the Swedish Nuclear Fuel supply Company (STBF), and the U.S. Department of Energy (DOE) through the Lawrence Berkeley Iaboratory (IBL) .

The principal investigators are I. B. N1lsson and 0 . Degerman for SkBF, and N. G. W. Cook, B. A. Witherspoon, and J. E. Gale for HBL. Other participants appear as authors of the Individual reports.

Technical reports in this serles are listed below. Not all of the listed reports are specifically referred to in the text.

SAC-01. P. A. Fitherbpoon and 0 . Degerman, Svedish-American Cooperative Program on Radioactive Waste storage in Mined Caverns, Lawrence Berkeley Laboratory, Berkeley, Ch, LBL-7049, 1978.

SAC-02. Lars Lundstrom and Haken st1lle, Large Scale Fermeability Test of the Granite in the stripa wine and Thermal conductivity Test, Larrence Berkeley Laboratory, Berkeley, Ch, IBL-7052, 1978.

SAC-03. Graham Swan, The Hechanical properties of the Stripa Granite, Lawrence Berkeley Laboratory, Berkeley, CA, LBL-7074, 1978.

SAC-04. H. Carlason, stress Measurenents in the Stripa Granite, Lawrence BerkeIey Laboratory, Berkeley, CA, IBL-7078, 1978.

SAC-05. Pavel J. Kurfurst, T. Hugo-Persson, and G. Rudolph, Borehole Drflling and Related Activities at the Stripa Mine, Lawrence Berkeley Laboratory, Berkeley, CA, LBL-7080, 1978.

SAC-06. Hans Carlsion, A P1lot Heater rest in the stripa Grantte, Lawrence Berkeley Laboratory, Berkeley, CA, LBI-7086, 1978.

SAC-07. Dennis B. Jamigon and keville G. W. Cook, An Analysts of Measured Values for the state of stress in the Earth's Crust, Lawrence Berkeley Laboratory, Berkeley, Ch, LBL-7071, 1978.

sAc-08. B. Anderason and P. A. Halen, MIning Methods Used in the Underground Tunnels and Test Roons at Stripa, Lawrence Berkeley Laboratory, Berkeley, CA, LBL-7081, 1978. 
sac-09. Tin Chan, Nevilie G. W. Cook, and Chin-Fu Tsang, Theoretical Temperature Flelds for the Stripa Beater Profect, Lawrence Berkeley Laboratory, Berkeley, CA, IBL-7082, 1978.

shc-10. Neville G. H. Cook, Nechanical and Thermal Destgn Constaerations for Radloactive Waste Repositorles in Hard Rock. Part I: An Apprafsal of Hard Rock for Potential Underguound Repositorfes of Radioactive Wastesi Neville G. W. Cook and Paul A. Witherspoon, Part II: In Situ Heating Experiments in Hard Rock: Their Objectives and Design, Lawrence Berkeley Laboratory, Berkeiey, CA, IBL-7073, 1978.

sac-11. Neville G. W. Cook and Hichael Hood, rull-Scale and Time-scale Heating Experiments at Stripa: Prelimfnary Results, Iawrence Berkeley Laboratory, Berkeley, CA, IBL-7072, 1978.

sac-12. P. Fritz, J. F. Barker, and J. E. Gale, Geochenistry and Isotope Bydrology of Groundwaters in the Stripa Granite: Results and Preliminary Interpretation, Lawrence Berkeley Iaboratory, Berkeley, CA, LRI,-8285, 1979.

SAC-13. R. H. Burlelgh, E. P. Binnall, A. O. DuBols, D. 0. Norgren, and A. R. Oritz, Electrical Heaters for Thermo-mechanical Tests at the stripa Mine, Iawrence Berkeley Laboratory, Berkeley, CA, IBI-7063, 1979.

SAC-14. Maurice B. McEvoy, Data Acquisition, Handiling, and Display for the Heater Experiments at Stripa, Iawrence Berkeley Laboratory, Berkeley. CA, LBL-7062, 1979.

sAC-15. J. E. Gale and P. A. Witherspoon, An Approach to the Fracture Hydrology at stripa: Preliminary Results, Lawrence Berkeley Iaboratory, Berkeley, CA, IBL-7079, 1979.

Sac-16. P. Nelson, B. Paulsson, R. Rachlele, L. Andersion, T. Schrauf, W. Hustrul1d, O. Duran, and K. A. Magnusson, Preliminary Report on Geophystcal and Mechanical Borehole Measurenents at Stripa, Lawrence Berkeley Laboratory, Berkeley, CA, LBL-8280, 1979.

SAC-17. P. A. Witherspoon, C. B. Amick, J. E. Gale, and K. Iwal, Observations of a Potentlal Size-Bffect In Bxperimental Determination of the Hydraulic Propertles of Fractures, Lawrence Berkeley Laboratory. Berkeley, CA, LBL-8571, 1979.

sac-18. P, A. Witherspoon, P. Nelson, T. Doe, R. Thorpe, B, Paulsaon, J. Gale, and C. Forster, Rock Mass Characterlation for storage of 
Nuclear Waste in Grantte, Lawrence Berkeley Laboratory, Berkeley, CA, LBL-8570, 1979 .

SAC-19. R. H. Waters, B. P. Palner, and W. E. Farre11, Fracture Detection is Crystaline Rock Using Shear Haves, Lawrence Berkeley Laboratory, Berkeley, Ch, IBI-7051, 1978.

SAC-20. R. Thorpe, Characterization or Discontimities in the Stripa GraniteTime Scale Beater Bxperikent, Lawrence Berkeley Laboratory, Berkeley. CA, LBL-7083, 1979.

SAC-21. A. Olkiewicz, J. E. Gale, R. Thorpe, and B. Paulsson, Geology and Fracture system at stripa, Lawrence Berkeley Laboratory, Berkeley, Ch, IBL-8907, 1979.

SAC-22. T. Chan and N. G. W. Cook, Calculated rhermally Induced Displacements and stresses for Beater Experiments at Stripa, Jawrence Berkeley Laboratory, Berkeley, CA, LBL-7061, 1979.

SAC-23, P. A. Witherspoon, J. Wang, K. Iwai, and J. E. Gale, Valldity of Cubic Law for Fluid Flow in a Deformable Rock Fracture, Lawrence Berkeley Laboratory, Berkeley, Ch, LBL-9557, 1979.

SAC-24. J. Jeffry, T. Chan, N. G. W. Cook and P. A. Witherspoon, Determination of In-Situ whermal Properties of stripa Granite from Temperature Measurements in the Full-scale Beater Experiments: Methods and PrImary Results, Lawrence Berkeley Laboratory, Berkeley, CA, LBL-8424, 1979

SAC-25. T. Schrauf, H. Pratt, E. Simonson, W. Hustrulid, P. Nelson, A. DuBols, E. Binnall, and R. Baught, Instrumentation Evaluation, Calibration, and Installation for Heater Tests stmulating Nuclear Waste in Crystalline Rock, Sweden, Lawrence Berkeley Laboratory, Berkeley, CA, IBI-8313, 1979.

SAC-26. M. Hood, Part I: Some Results from a Fleld Imvestigation of Thermo-Hechanical Loading of a Rock Mass when Beater Canisters are Emplaced in the Rock; H. Hood, H. Carlsson, and P. H. Nelson, Part II: The Application of Fleld Data from Beater Experiments Conducted at Stripa, Sweden for Respository Deslgn, Lawrence Berkeley Laboratory, Berkeley, CA, IBL-9392, 1979.

saC-27. R. A. Witherspoon, N. G. W. Gook, and J. E. Gale, Progress with Fleld Investigations at stripa, Lawrence Berkeley Laboratory, Berkeley, CA, IBL-10559, 1980 . 
sAC-28. C. B. Forster and J. E, Gale, A Laboratory Assessment of the Use of Borehole Pressure Transtents to Measure the Perweability of Fractured Rock Masses, Lawrence Berkeley Laboratory, Berkeley, Ch, LBL-8674, 1980.

SAC-29. T. Chan, E. Binna11, P. Nelbon, O. Wan, C. Weaver, K. Ang, J. Braley, and M. HoBvoy, Thermal and Thermomechanical Data for In Situ Heater Bxperiments at Stripa, Sweden, Lawrence Berkeley Laboratory, Berkeley, CA, LBI-11477, 1980.

SMC-30. P. H. Nelson, R. Rachlele, and A. Sinth, The Bffect of Radon Transport In Groundwater Upon Gama Ray Borehole Logs, Lawrence Berkeley Laboratory, Berkeley, CA, LBL-11180, 1980.

SAC-31. R. Thorpe, D. J. MatkIns, M. E. Ralph, R. Hsu, and S. Flexser, Strength and Permeability Tests on UItra-Large Stripa Granite Core, Iawrence Berkeley Iaboratory, Berkeley, Ch, LBL-11203, 1980.

\section{B. Other references}

1. P. A. Witherspoon, N. G. พ. Cook, and J. E. Gale, Waste Management Conf., Tucson, Artzona, 1980.

2. R. A. Freeze and J. A. Cherry, Grounoivater (Prent1ce-Hall, 1979).

3. XBS-II Report, Volune II, p. 116.

4. W. Dansgaard, stable 18otopes in precipitation. Tellus, 16, 436 (1964). 


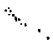

$c-36$ 


\section{APPENDIX D}

EOUATIONS FOR FRACHURE CONDOCTIVITY (SAC-17)

Equations describing fluid flow between two parallel plates have been dertved by Polubarinova-xochina (1962), Snow (1965), Louls (1969), Noorishad, Witherspoon, and Brekke (1971), Bear (1972), Gale (1975) and several other workers in the field of fracture flow. These authors have show that the intrinsic permeability of a fracture with an aperture of $2 \mathrm{~b}$ is given by

$$
k_{f}=\frac{(2 b)^{2}}{12}
$$

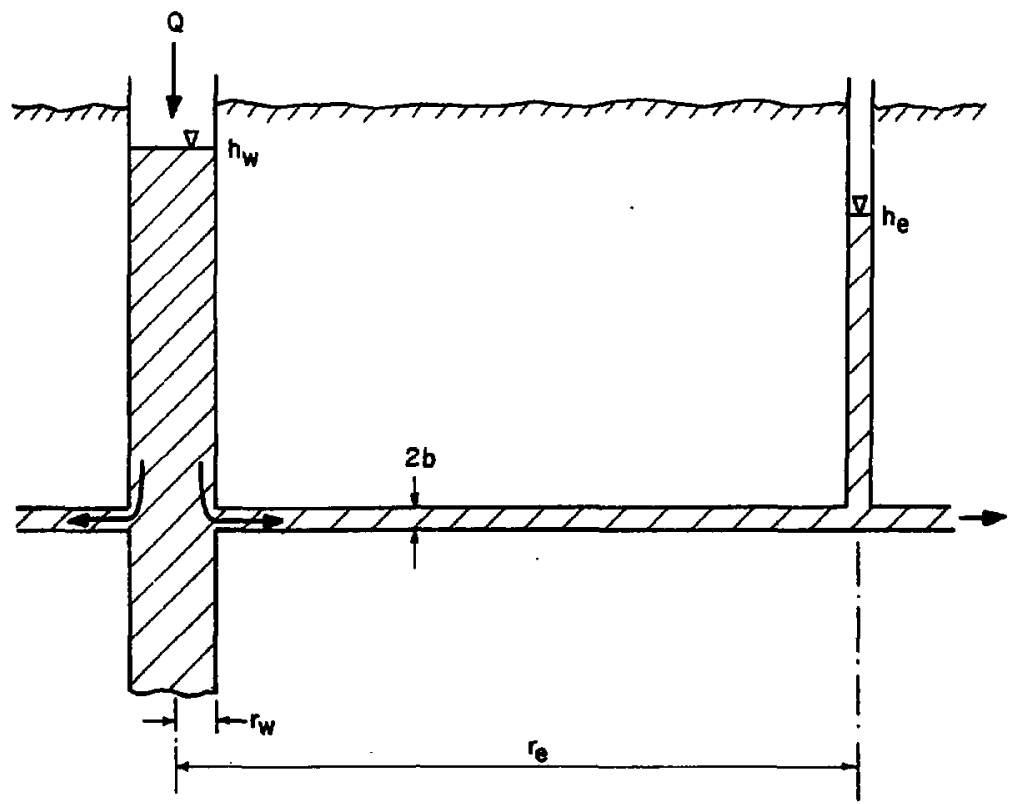

FIG. D-1. Radial flow from a well Into a horizontal fracture. D-1 
and this may be converted to the hydraulic conductivity of a fracture by

$$
R_{E}=\frac{k_{E} \rho g}{\mu}=\frac{(2 b)^{2} \rho g}{12 \mu} .
$$

If one has steady-state radial flow from a borehole into a horizontal fracture (as shown in Fig. D-1) and the hydraulic head drops from $h_{w}$ at the well bore radius $r_{w}$ to $h_{e}$ at the outer radius $r_{e}$, then the injection rate, $Q$, may be determined from Darcy' $B$ law and is given by

$$
Q=\frac{2 \pi(2 b)^{3} \rho g\left(h_{w}-h_{e}\right)}{12 \mu \ln r_{e} / I_{w}} .
$$

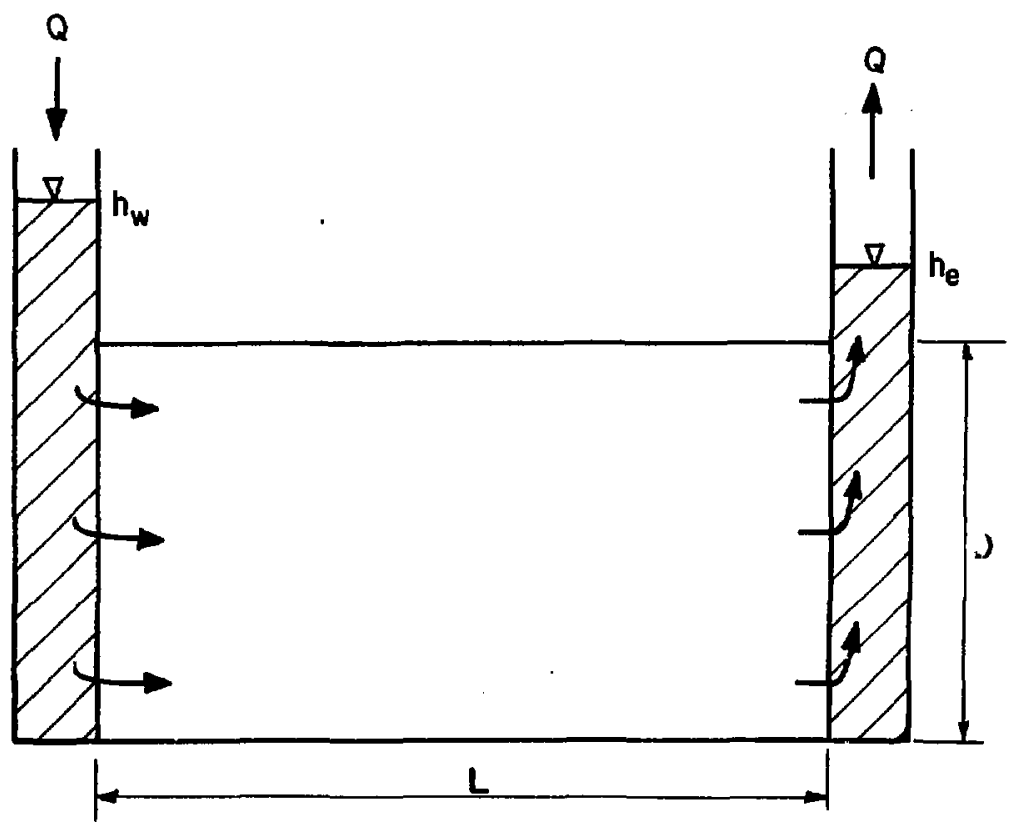

FIG. D-2. Linear flow in a vertical fracture.

D-2 
In laboratory Investigations where the aperture 1B unknown, Eg. (D3) can be used to solve for $2 b$ directly, since all other parameters are neasurable. The hydraulic conductivity can then be determined using Eq. (D2).

If one has steady-gtate linear flow in a vertical fracture of extent $D$ (as shown In FIg. D-2) and the hydraulic head drops from $h_{w}$ to $h_{e}$ over length ${ }_{\text {, }}$ then the flow rate, $Q$, may be determined from

$$
Q=\frac{(2 b)^{3} \rho g D\left(h_{w}-h_{e}\right)}{12 \mu L}
$$

In experimental investigations, Eq. (D4) can be used to bolve for 2b, and Eg. (D2) to Bolve for $k_{f}$. 
1. J. Bear, Dynamics of Flulds in Porous Media. (Amer. Blsevier Publishing Company, New York, 1972).

2. J. E. Gale, A Numerical Fleld and Laboratory Study of Flow in Rocks with Deformable Fractures. Ph.D. Thesis, Oniversity of California, Berkeley, CA (1975).

3. C. Louib, A study of Groundwater Flow in Jolnted Rock and its Influence on the Stability of Rock Hasses. Imperial college Rock Mechanics Research Report No. 10, Imperial College, London (1969).

4. J. Noorishad, P. A. Witherspoon, and T. L., Brekke, A Method for Coupled Stress and Flow Analysis of Fractured Rock Masses. Geotechnical Engineering Report No. 71-6, University of California, Berkeley, CA (1971).

5. P. Ya. Polubarinova-Rochina, Theory of Groundwater Novement. Translated by J. M. R. Dewiest. (Princeton University Preag, Princeton, NJ, 1962).

6. D. T. Snow, A Parallel Plate yodel of Fractured Permeable Media. Unpublished Ph.D. Dissertation, University of California, Berkeley, CA. 
THE IAW ON NUCLERR WASTE, JULY 1, 1981 (TRMNSATION).

An Act Concerning the Financing of Future Expenditure for Spent Nuclear Fuel, Etc.

Issued as of 18 June, 1981

It is hereby promulgated as follows.

\section{Section 1}

The holder of a license pursuant to the Nuclear Energy Act (1956:306) to own or operate a nuclear reactor for power generation (the reactor owner) shall be responsible for ensuring that

1. nuclear fuel irradiated in the reactor and radioactive waste deriving therefrom is handled and disposed of in a safe manner,

2. the reactor facisfty will be shut down and dismantled in a safe manner, and

3. such research and development activities are conducted and other measures taken as are required to ensure compliance with the provisions under 1 and 2 above.

\section{Section 2}

In addition to the costs resulting from its obligations pursuant to Section 1, the reactor owner shall also be liable in respect of costs incurred by the State for

1. research and development activities supplementary to those referred to in section 1, 1 tem 3,

2. review of the matters referred to in the recond paragraph of section 5 and in section 10 , and

3. Surveiliance and inspection of final repositories. 
Section 3

In consultation with other reactor owners, the reactor owner shall establish a progran for such research and development activities and other measures as are referred to In section 1 . The progran shall contain an outline of all measures which way becone necessary and shall specify wore detall the measures intended to be implemented within a perfod of at least the next five years. The program shall be annually updated.

The program shall be subnitted annually to the Government or to the authority designated by it.

\section{Section 4}

The authority designated by the Governuent shall establish a progran of the activities referred to in section 2 , 1 tems 1 and 3 .

\section{Section 5}

In order to ensure the avallability of funds to cover the costs resulting from the reactor owner's obligations pursuant to Section 1 and the costs referred to in Section 2, an annual fee shall be payable by the reactor owner to the state for ouch time as the reactor is in operation. As far as the costs for the handling and final disposal of opent nuclear fuel are concerned, the obligation to pay the annual fee shali relate to such costs attributable to the fuel after its removal from the reactor facility. The fee shall be proportionate to the energy delivered by the reactor facility.

The amount of the fee shall be established annually in respect of the succeeding calendar year by the Government or the author 1 ty designated by it.

The annual fee shall be established such that the aggregate anount of fees paid during the operating life of the reactor shall cover the costs referred to in the first paragraph of this section 5 .

\section{Section 6}

The annual fee shall be established on the basis of the programs referred to in Sections 3 and 4 and the estlated expeinditure in respect of the 
measures referred to In Sections 1 and 2. With regard to measures referred to in Section 1, consideration shall be given to seasures previously adopted for the disposal of spent nuclear fuel and radioactive waste deriving therefrom, to the characteristics of the reactor, and to other clrcumstances which may Influence the calculation of the fee.

If the basis for the calculation of the fee is lacking or inadequate, the fee shall be established at a reasonable anount.

\section{Section 7}

The fee shall be paid to the authority designated by the covernment. Collected fees shall be deposited by it in an interest-bearing account with the National Bank of Sweden Accrued intereat shall be capitallzed.

\section{Section 8}

Loans may be granted to a reactor owner out of this fees paid in by it againgt the provision of collateral.

Such loans shall carry interest at a rate no less than that given by the National Bank of sweden on the collected fees deposited with 1t. Interest paid shall be deposited in the account referred to in Section 7 and shall be capitalized.

Loans shall otherwise be subject $\leftleftarrows$, such terms and conditions as are required to ensure the avallability of funds for the purposes referred to in Section 9.

\section{Section 9}

Fees paid by a reactor owner may be used in rei-bursement of the costs Incurred by the reactor owner in respect of reasures referred to in Secticn 1 subject to the limitation resulting from the provisioh. in the second sentence of the first paragraph of section 5 and further to defray the costs incurred by the state in respect of measures referred to in Sections I and 2 which are attributable to the reactor or to fuel utilized in the reactor. 


\section{Section 10}

Matter relative to supplementary research and develogent activities, survelliance and Inapection of final repositories, loans to reactor owners out of renltted fees and the terms and condltions of such loane, as well as the application of collected fees shall be reviewed by the Government or the authority designated by it.

\section{Section 11}

Upon request, the reactor ormer sha.'l provide such information and such locuments as are necrssary for the Goverment or the authority designated by it to establish the fee in accordance with the second paragraph of section $B$ and to review the matters referred to in section 10 . To the extent required for the aforementioned purposes, the reactor owner upon request shall further grant access to facilities or sites where spent nuclear fuel or radioactive waste deriving therefrom is stored or handled.

\section{Section 12}

Anyone who, intentionally or through gross negligence, provides incorrect information or otherwlse diaregards his obligations pursuant to section 11 shall be liable to a fine, unless the deed is punishable under the Criminal Code.

This Act shall come into effect on $1 \mathrm{July}, 1981$, provided that the provistons of the flrst paragraph of section 5 shall apply as frcm calendar year 1982 . 